\title{
THE MODERN WOMAN IN THE MIRROR
}

\section{Modernity and the New Zealand Women's Magazine 1922-1932}

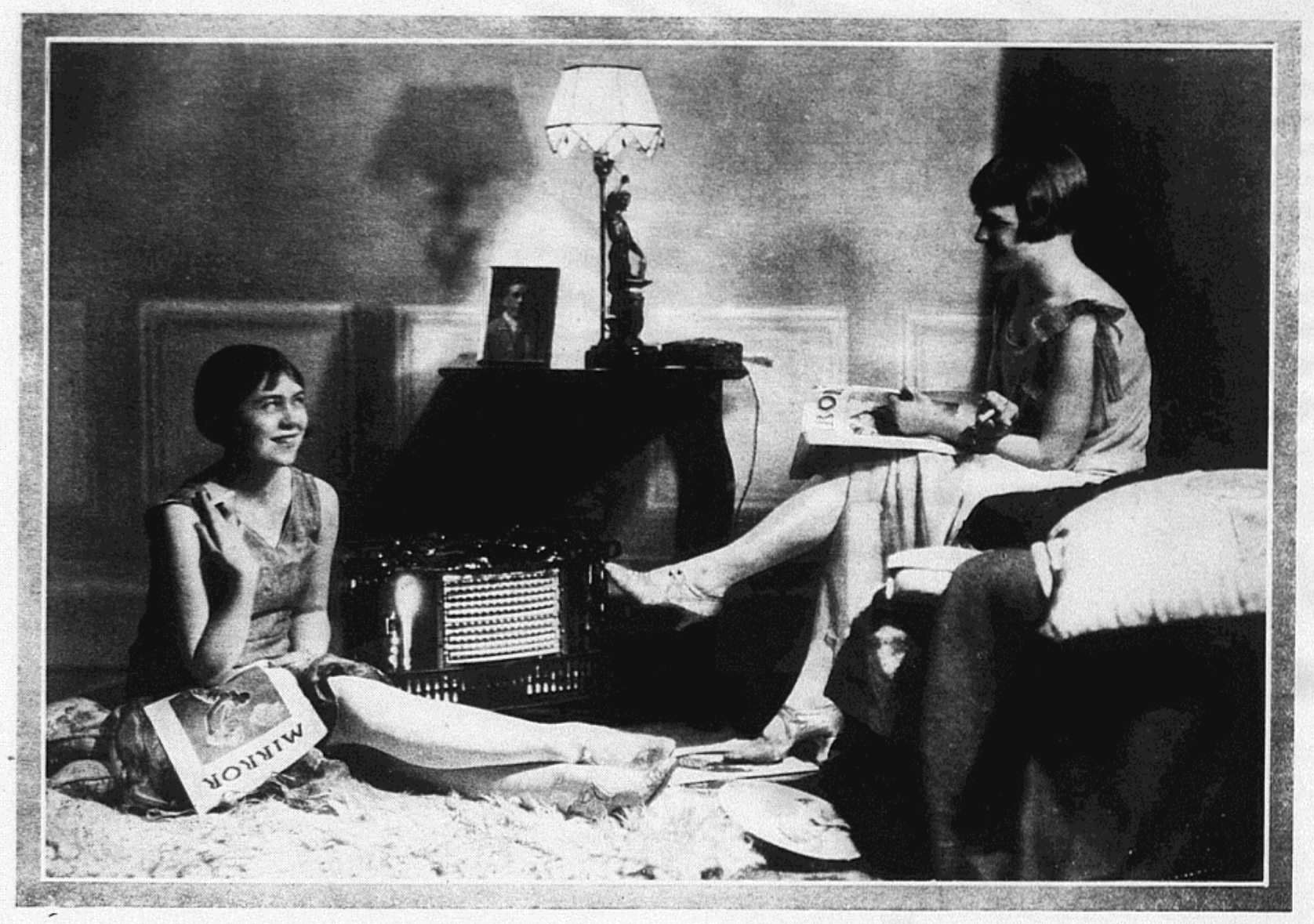

A thesis submitted to Victoria University of Wellington in fulfilment of the requirements for the degree of Master of Arts in History

Jessie Annett-Wood 



\begin{abstract}
In 1922 a new women's magazine, The Ladies' Mirror, was launched in Auckland. The first magazine of its kind in New Zealand, The Mirror sought to provide New Zealand women with their own space in print, and contained a wide array of content, including fashion notes, housekeeping advice, and social and political discussion pieces. This thesis uses The Mirror's first decade to explore the relationship between New Zealand women and modernity in the early twentieth century. The Mirror appeared at a time that was conspicuously and self-consciously modern, and it presented itself as a magazine for the modern woman in an era of change. Women and modernity are often presented as having a fraught relationship, but The Mirror presented a modern world in which women's lives were being improved and enhanced.
\end{abstract}




\section{Acknowledgements}

I am grateful to my supervisor, Charlotte Macdonald, for her help and encouragement with this project. I am thankful also to Kate Hunter, who agreed to step in during Charlotte's absence as interim supervisor. I was lucky enough to receive the Jack Pearce Postgraduate Scholarship in History, and I would like to thank Jack Pearce's family for their kind donation. I would also like to thank the rest of the staff and students in the Victoria history department for making this such a rich and rewarding place to study. Thanks in particular are due to Grace Millar, Stephen Clarke and Sarah Burgess who read parts of this thesis for me and provided useful feedback. I would also like to thank Joe Cruden, Nicola Braid, Rob Kelly and David Hill, whose participation in our thesis group along with Stephen and Sarah made me feel much less alone in undertaking such a daunting task. I could also not have done this without the support of my mum and dad, and the friendship of Vee, Josh, Romana and Lily. Finally, I would like to thank Emily, who never let me feel too sorry for myself and who was always on hand with an inspiring power ballad and a piece of cake. 


\section{Contents}

List of Images $\quad$ iv

$\begin{array}{lr}\text { Introduction } & 1\end{array}$

1. A Space for Women 20

2. The Girl of Today 39

3. Modernity in the Home: An End to Drudgery 58

4. Imperial Modernity: The Mirror and the 1927 Royal Tour 81

$\begin{array}{ll}\text { Conclusion } & 102\end{array}$

$\begin{array}{ll}\text { Bibliography } & 108\end{array}$ 


\section{List of Images}

'Up-To-Date'

Cover

Pawlyn Huggett, The Mirror, October 1926, p. 2.

'The Holiday Girl'

45

Cover, The Mirror, January 1927

'The Most Dangerous of the Flappers'

Samuel Cahan, from John Thorton, 'Dream Girl', The Mirror, October 1928, p. 28.

'Are You 1905 in Home Cleaning Methods?'

65

Electrolux vacuum cleaner advertisement, The Mirror, December 1931, p. 58.

'Royal Souvenir Number'

Cover, The Mirror, April 1927.

All images taken from copies of The Mirror held at the National Library of New Zealand and scanned by New Zealand Micrographic Services. 


\section{Introduction}

In July 1922 a new magazine was launched in Auckland. Named The Ladies' Mirror: The Fashionable Ladies' Journal of New Zealand, it was a monthly magazine aimed at middle class New Zealand women. The Mirror appeared at a time that was conspicuously and self-consciously modern, as demographic changes, new forms of technology from the car to the electric kettle, and an increasingly globalised commodity culture, all brought noticeable change to people's lives. Particularly conspicuous, it seemed, was the modernity of women. 'Modern women' were independent and self-sufficient. They smoked and drank; they postponed marriage and took careers instead. Even their appearance was radically different. Gone were the exaggerated feminine curves of the Victorian and Edwardian woman, replaced with short and boxy dresses which minimised the appearance of breasts or hips. Hair was short. No longer was make-up a sign of questionable morality; indeed, to go without was to risk selling oneself short. These changes were met with mixed emotions; for some, the modern woman was a threat, for others she was a sign of progress. This study tracks The Mirror over the course of its first decade in print, from 19221932, and explores the relationship between New Zealand women and modernity in the pages of The Mirror in the early twentieth century.

The Mirror's first issue made a bold claim for the magazine to be seen as something new and important:

In the multiplicity of New Zealand publications is there room for a journal devoted entirely to the interests of women? Room! There is absolute necessity; for in this wide Dominion, which can boast more papers to the square inch than any other national entity, while masculinity is catered for in every phase, trade, profession, federation of employers, union of works, farm garden, orchard, each having its special advocate, no attempt has been made, until this, our first issue, to satisfy the craving which exists in the heart of every thoughtful woman for a medium which will give expressions to her 
own desires, aspirations and ideals. And that is the reason for this paper coming into being. 1

New Zealand was a nation with a rich print culture, but The Mirror, it argued, was unique in catering to women. Sold for a shilling, The Mirror contained all of the usual content associated with a women's magazine - fashion and beauty tips, social news, patterns and recipes. It also contained more surprising elements its sports and motoring sections were substantial, as was often its political commentary. It openly advocated for improvements in women's social position, arguing strongly in favour of their potential for positive influence if given more public roles. Its content often projected a reader that was independent and savvy - the 'thoughtful woman'. While various journals had contained content for women in the past, and many newspapers still did contain some kind of women's column or page, none of them came close to the range of content available in The Mirror. The Mirror was New Zealand's first example of the modern women's magazine.

The Mirror was one of many New Zealand magazines that first appeared in the interwar period, many of which were highly successful. While locally produced newspapers had flourished in the nineteenth century, periodicals had struggled to compete with the wide range of imported magazines available in New Zealand. $^{2}$ In the interwar period, however, New Zealand magazines began to experience considerable popular success. One of The Mirror's key contemporaries was the New Zealand Railways Magazine, which was published from 1926 by the Railways Department. Originally intended as a vehicle for railway news and tourist promotion, it published a wide range of New Zealand short fiction. In a similar vein was The New Zealand Listener, which appeared later, in 1939. Although initially conceived strictly as a broadcasting magazine in which to publish the radio listings, the Listener quickly expanded to include

\footnotetext{
1 'Editorial Reflections', The Ladies' Mirror, July 1922, p. 10.

2 J. Reginald Tye, 'New Zealand', in J. Don Vann and Rosemary T. VanArsdel (eds.), Periodicals of Queen Victoria's Empire (Toronto: University of Toronto Press, 1996), p. 203.
} 
book reviews and original fiction. As regular publishers of local content, these magazines played a significant role in New Zealand's emerging literary scene. In a different direction, but no less significant, was The New Zealand Dairy Exporter and Farm Home Journal. The Dairy Exporter was one of New Zealand's most popular periodicals of the period, with a circulation in the late 1920s three times that of The Mirror. Its women's section was highly popular with rural women, particularly while under the editorship of Norah Burnard from 1932. ${ }^{3}$ The Listener and the Railways Magazine may have helped to build New Zealand's literary culture, but the popularity of the Dairy Exporter with rural families speaks to another important role periodicals had in connecting New Zealanders.

The Mirror's claim that there was plenty of room for magazines devoted to women was also put to the test, with new magazines taking the concept of the women's magazine in very different directions. The New Zealand Women's Weekly began publication in 1932. A weekly magazine that was both shorter and cheaper, it focused less on the political and social issues that regularly appeared in The Mirror and stuck more closely to the basic women's magazine formula of recipes, royals and romance stories. From a more radical direction came Working Woman, a magazine created by the women of the Communist Party. Begun in 1934, Working Woman drew attention to the plight of workingclass women, and included articles on Māori issues, often written in Māori. In 1936 Working Woman folded, but it was quickly replaced by a new, cross spectrum feminist magazine, Woman To-Day, which began in 1937.4 Women ToDay had a less explicitly working-class focus, but like Working Woman, it drew attention to women's issues not often acknowledged elsewhere. It was, for instance, one of the only magazines to support the Sex Hygiene and Birth

\footnotetext{
${ }^{3}$ Charlotte Macdonald, 'Burnard, Norah Telford', Dictionary of New Zealand Biography, Vol. 5, 2000, http://www.teara.govt.nz/en/biographies/5b49/burnard-norah-telford, accessed 14 Jan 2015.

4 'By Women, For Women, About Women: The Feminist Press in New Zealand', in Sandra Coney (ed.), Standing in the Sunshine: A History of New Zealand Women Since They Won The Vote (Auckland: Penguin Books, 1993), pp. 134-135.
} 
Regulation Society (now Family Planning) when it was established in 1936. Woman To-Day struggled with communist associations (although not actually a communist magazine), and did not survive past 1939, but Women's Weekly was highly successful and is still in print today.

New Zealand's print culture has received slightly uneven attention, and the majority of these magazines have as yet received little scholarly focus. Newspapers have fared slightly better; Guy Scholefield's 1958 Newspapers in New Zealand provided a comprehensive overview of New Zealand's newspaper history that has since been supplemented by work by Redmer Yska, David Hastings and Tony Ballantyne, amongst others. ${ }^{5}$ Lydia Wevers' Reading on the Farm is an excellent study into the reading habits of New Zealanders in the late nineteenth century, but one that focuses on books, especially novels. ${ }^{6}$ Periodicals have received less attention. Those blessed with longevity have occasionally published their own celebratory histories, as the New Zealand Women's Weekly did on both its $60^{\text {th }}$ and $70^{\text {th }}$ print anniversaries. ${ }^{7}$ Others have appeared prominently as sources in histories of other topics. Women's Weekly, for instance, is one of three key sources used by R. F. North in her 1993 thesis, 'Representations of Women in New Zealand'.8 Another source of information about New Zealand periodicals comes from the work of literary scholars, but their primary interest is usually in magazines' role in facilitating the

\footnotetext{
${ }^{5}$ Guy H. Scholefield, Newspapers in New Zealand (Wellington: A. H. \& A. W. Reed, 1958); Redmer Yska, Truth: The Rise and Fall of the People's Paper (Nelson: Craig Potton Publishing, 2010); David Hastings, Extra! Extra! How the People Made the News (Auckland: Auckland University Press, 2013); Tony Ballantyne, 'Reading the Newspaper in Colonial Otago', Journal of New Zealand Studies, No. 12, 2011, 47-63.

${ }^{6}$ Lydia Wevers, Reading on the Farm: Victorian Fiction and the Colonial World (Wellington: Victoria University Press, 2010).

7 Janet Blackwell (ed.), NZ Woman's Weekly: The First 60 Years, 1932-1992 (Auckland: Moa Beckett Publishers, 1992); Jenny Lynch, New Zealand Woman's Weekly: 70 years from Pavlovas to Prime Ministers (Auckland, Random House, 2002).

${ }^{8}$ R. F. North, 'Representations of Women in New Zealand: A Study of Parliamentary Debate, the New Zealand Woman's Weekly, and Broadsheet, from the 1950s to the 1980s', MA Thesis, University of Auckland, 1993.
} 
establishment of a distinct New Zealand literary canon. ${ }^{9}$ As a result they generally pay less attention to non-literary content. Despite the uneven focus of some of these studies, together they do indicate that, as The Mirror attested, New Zealand was a nation with a rich print culture. Both Wevers' work on the Brancepeth Station Library and work by Susann Liebich highlight New Zealand as a land of readers; consumers of a wide range of print media, both imported and locally produced.10

These differing priorities have shaped existing understanding of The Mirror. Like the Listener and the Railways Magazine, The Mirror published both fiction and non-fiction from New Zealand writers. But it has not been regarded as having much literary clout, meaning that when it does feature in literary histories it is generally as a magazine which declined to publish the work of Frank Sargeson, preferring to publish fiction in which, according to Chris Hilliard, "conventional sentiments about marriage and gender roles abounded".11 Nevertheless, it is a literary study which contains the most expansive research on The Mirror to date - Stephen Hamilton's thesis on 'New Zealand Periodicals of Literary Interest', which includes a section dedicated to The Mirror. Hamilton classifies The Mirror as a conservative middle-class magazine. In Hamilton's eyes, the magazine's early claims to be a rallying point for New Zealand feminism were undermined from the very beginning by its emphasis on women's domestic role, through which "the Mirror aligned itself with the conservative belief that women, who during the labour shortages occasioned by World War One had taken an unprecedented role in the work force, should now step back into their more traditional role of mothers and

\footnotetext{
${ }^{9}$ Dennis McEldowney, 'Publishing, Patronage, Literary Magazines', in Terry Sturm (ed.) The Oxford History of New Zealand Literature, $2^{\text {nd }}$ Ed. (Auckland: Oxford University Press, 1996), pp. 631-694.

10 Wevers; Susann Liebich, 'Connected Readers: Reading Practises and Communities Across the Empire, c. 1890-1920', PhD Thesis, Victoria University of Wellington, 2012.

${ }^{11}$ Chris Hilliard, The Bookmen's Dominion: Cultural Life in New Zealand 1920-1950, (Auckland: Auckland University Press, 2006), p. 32.
} 
wives".12 This tendency towards conservatism apparently only increased as time progressed, and Hamilton argues that by the 1930s the magazine had abandoned any "non-radical feminism" in support of traditional roles for women. ${ }^{13}$

The Mirror has also been used by historians as a significant primary source. Helen Leach, Jean-Marie O'Donnell and Danielle Sprecher have all utilised different content from The Mirror in studies of the home and the office, affirming its value as a source of information about life in New Zealand, particularly for women. ${ }^{14}$ Jenn Corbitt has studied The Mirror's advertisements for insight into the construction of gender and modernity in interwar New Zealand. ${ }^{15}$ Corbitt's study views The Mirror as modern, rather than conservative, however she concludes that while the magazine promoted reader identification with the modern woman, this modernity was "not situated in radical political or social action and ideas, but instead within the transformative potential and power of consumer (modern) products". ${ }^{16}$ This is perhaps not an entirely surprising conclusion when advertisements are the main evidence examined, but Corbitt's study is one of few that focuses specifically on The Mirror, and her insights are valuable, particularly regarding its role within the realm of consumption.

It was not just New Zealand where print media was expanding. By the end of the nineteenth century increased literacy and cheap printing technology had ensured consumption of print publications ceased to be the preserve of the elite

\footnotetext{
${ }^{12}$ Stephen Hamilton, 'New Zealand English Language Periodicals of Literary Interest Active 1920s-1960s', PhD Thesis, University of Auckland, 1996, p. 449.

${ }^{13}$ Hamilton, 'Periodicals of Literary Interest', p. 484.

${ }^{14}$ Helen Leach, Kitchens: The New Zealand Kitchen in the $20^{\text {th }}$ Century (Dunedin: Otago University Press, 2014), pp. 74-76; Danielle Sprecher, 'Good Clothes are Good Business: Gender, Consumption and Appearance in the Office, 1918-39', in Caroline Daley and Deborah Montgomerie (eds.) The Gendered Kiwi (Auckland: Auckland University Press, 1999) pp. 141162; Jean-Marie O'Donnell, “Electric Servants' and the Science of Housework: Changing Patterns of Domestic Work, 1935-1956', in Barbara Brookes, Charlotte Macdonald and Margaret Tennant (eds.), Women in History 2 (Wellington: Bridget Williams Books, 1992), pp. 168-183.

${ }^{15}$ Jenn Corbitt, "Shimmering Images": Gender, Modernity and The Mirror, 1922-1938', BA Hons Thesis, Victoria University of Wellington, 2000.

16 Ibid, p. 59.
} 
and became an activity of the masses. ${ }^{17}$ Adrian Bingham argues that daily newspapers were one of the most successful products of the interwar period in Britain, where circulation figures doubled. ${ }^{18}$ Susann Liebich stresses the importance of print media at a point where cinema and radio were still establishing themselves, both as entertainment and as a means for transmitting news and information. ${ }^{19}$ By the time The Mirror appeared in 1922, film, and to a lesser extent, radio, were gaining popularity in New Zealand, but they still did not yet have the reach of print. Magazines and newspapers could also, as David Carter claims for popular Australian monthly Aussie, function as "a mode of apprehending modernity". ${ }^{20}$ This burgeoning print industry included women's magazines, which diversified from the society journals and fashion plates of the nineteenth century to take on new forms which appealed to a broad range of women. Cynthia White, whose 1970 work Women's Magazines remains the most comprehensive study of the women's press in Britain, describes this period as one dominated by the rise of cheap 'service' journals; magazines that primarily provided domestic advice for the servantless middle-class housewife: Good Housekeeping, for instance, or Woman's Own. White identifies the proliferation of these new service magazines as a turning point in women's journalism, a reorientation away from the leisured classes towards 'the middle ranks'.21 Many of these publications found their way to New Zealand, where they were consumed alongside more local content like The Mirror.

White was one of the first to argue for women's magazines to be considered as an important cultural phenomenon and significant historical source. A number of scholars have since taken up her charge that women's magazines deserve

\footnotetext{
17 Ros Ballaster, Margaret Beetham, and Sarah Hebron, Women's Worlds: Ideology, Femininity, and the Woman's Magazine (Houndmills: Macmillan, 1991), p. 76; Adrian Bingham, Gender, Modernity and the Popular Press in Inter-War Britain, (Oxford: Clarendon Press, 2004), p. 3. 18 Bingham, p. 3.

19 Liebich , p. 2

${ }^{20}$ David Carter, “'Esprit de Nation” and Popular Modernity: Aussie magazine 1920-1931', History Australia, Vol. 5, No. 3, 2008, p. 74.1.

${ }^{21}$ Cynthia L. White, Women's Magazines 1693-1968 (London: Michael Joseph Ltd, 1970), pp. 9596.
} 
serious study. Janice Winship's Inside Women's Magazines, Ros Ballaster, Margaret Beetham, Elizabeth Frazer and Sandra Hebron's Women's Worlds and Margaret Beetham's A Magazine of Her Own? all explore the rich world of the women's press and demonstrate that women's magazines are a valuable source that can be particularly elucidating about gender. ${ }^{22}$ These historians have, however, had to deal with the fact that women's magazines are often viewed suspiciously as regulators of femininity. Many authors of works on women's magazines note the personal tensions between their own position as readers who gain substantial pleasure from these magazines, and as feminists aware of the many criticisms of these works as lowbrow, oppressive media. ${ }^{23}$ Winship, for instance, notes her fear that her feminist peers were silently judging her topic of study, asking: “Surely we all know women's magazines demean women and solely benefit capitalist profits. What more is there to say?"24 According to Anna Gough-Yates, women's magazines are often portrayed as a media of manipulation, "a key site through which oppressive feminine identities are constructed and disseminated".25

Certainly, women's magazines often provide readers with suggestions about enhancing their femininity. As Margaret Beetham has noted, "becoming the woman you are is a difficult project for which the magazine has characteristically provided recipes, patterns, narratives and models of the self." 26 The woman's magazine can act as a blueprint, suggesting appropriate ways for the reader to perform her role as woman. Chanel Hughes's study of The Canterbury Times Ladies' Page describes it as a space for 'gender enculturation", "the newspaper becoming simultaneously a reflector and

\footnotetext{
22 Ballaster et al; Janice Winship, Inside Women's Magazines (New York: Pandora, 1987); Margaret Beetham, A Magazine of Her Own?: Domesticity and Desire in the Women's Magazine (Routledge, New York, 1996).

${ }^{23}$ Ballaster et al, p. 1; Winship, p. xiii; Beetham, p. viii.

${ }^{24}$ Winship, p. xiii.

25 Anna Gough-Yates, Understanding Women's Magazines: Publishing, Markets and Readerships (London: Routledge, 2003), p. 7

26 Beetham, p. 1.
} 
establisher of gender definitions and roles". ${ }^{27}$ However, if women's magazines do play a role in the construction of femininity, then it must be acknowledged that they have the power to expand or subvert gender norms as well as enforce them. Joanne Meyerowitz's survey of postwar American women's magazines stresses that they offered much more diverse representations of femininity than might be expected. ${ }^{28}$ Beetham points out the "radical potential" of the magazine as a feminised space where "it is possible to challenge oppressive and repressive models of the feminine". ${ }^{29}$ In The Gender of Modernity Rita Felski asks the question: "how would our understanding of modernity change if instead of taking male experience as paradigmatic, we were to look instead at texts written primarily by or about women?"30 As texts that cater to women, women's magazines like The Mirror can provide insight into the female experience of modernity, often revealing a more complex picture of the modern woman than might be assumed.

Felski seeks to undermine the way in which modernity has often been associated with masculinity, but it is also worthwhile to acknowledge that many other historians have seen the 1920s as a period where modernity and femininity became more closely aligned. Sally Alexander points out that many of the new industries of the early twentieth century catered largely to feminine needs and desires - the cinema, the hairdresser, the department store - in contrast to the nineteenth century's "manly and strong" coal mines and textile mills. ${ }^{31}$ The Modern Girl Around the World Research Group, an interdisciplinary collective, uses the 'Modern Girl' to guide their exploration of modernity, consumerism, and globalisation across the world in the twenties

\footnotetext{
${ }^{27}$ Chanel Hughes, 'Dolce Cabot and the Canterbury Times "Ladies' Page": An Examination of Early New Zealand Women's Journalism', MA Thesis, University of Canterbury, 1998, p. 26. 28 Joanne Meyorwitz, 'Beyond the Feminine Mystique: A Reassessment of Postwar Mass Culture, 1946-1958', Journal of American History, Vol. 79, No. 4, 1993, pp. 1455-1482.

29 Beetham, p. 3.

${ }^{30}$ Rita Felski, The Gender of Modernity (Cambridge: Harvard University Press, 1995), p. 10.

31 Sally Alexander, 'Becoming a Woman in London in the 1920s and 1930s', in David Feldman and Gareth Stedman Jones (eds.), Metropolis London: Histories and Representations Since 1800 (London: Routledge, 1989), pp. 245-246.
} 
and thirties. They argue that this figure was recognisable worldwide as an emblem of modernity, and that she acted as "a harbinger of both the possibilities and dangers of modern life".32 The connection made by contemporaries between the behaviour and appearance of the so-called 'modern' woman and wider changes in society is one that has been observed by many historians. They note her prominence in the popular press, where her startlingly boyish appearance and her inclination for dancing, smoking and drinking were widely commented on. Lucy Bland looks at the most extreme examples of this phenomenon, studying the press coverage of women embroiled in scandalous court cases involving sex, drugs, and divorce. ${ }^{33}$ In Europe anxiety surrounding the modern woman was often associated with the First World War, and fears that the war had had an irreversible impact on society, particularly relationships between women and men. Mary Louise Roberts, Susan Kingsley Kent and Barbara Søland all situate their discussions of gender dynamics in the 1920 s firmly within a postwar context. ${ }^{34}$ However, historians like those involved in the Modern Girl Around the World project have found that anxiety did not always centre on the war. Discussions surrounding the modern girl varied from place to place and often were more representative of local concerns about the modern world than anything intrinsic to women themselves.

The extremes of the modern girl feature less obviously within New Zealand's historiography. Much of the historical debate surrounding women has focused on their political and economic progress, emphasising the interwar period as

\footnotetext{
32 Modern Girl Around the World Research Group, 'The Modern Girl as Heuristic Device: Collaboration, Connective Comparison, Multidirectional Citation', in The Modern Girl Around the World Research Group, The Modern Girl Around the World: Consumption, Modernity, and Globalisation (Durham: Duke University Press, 2008), p. 8.

${ }^{33}$ Lucy Bland, Modern Woman on Trial: Sexual Transgression in the Age of the Flapper (Manchester: Manchester University Press, 2013).

34 Mary Louise Roberts, Civilization Without Sexes: Reconstructing Gender in Postwar France, 1917-1927 (Chicago: University of Chicago Press, 1994); Brigitte Søland, Becoming Modern: Young Woman and the Reconstruction of Womanhood in the 1920s (Princeton: Princeton University Press, 2000); Susan Kingsley Kent, Making Peace: The Reconstruction of Gender in Interwar Britain (Princeton: Princeton University Press, 1993).
} 
one in which women continued to agitate for change. Dorothy Page's history of the National Council of Women notes that it was a period of resurgence for the organisation after a sharp decline in the first decades of the century. ${ }^{35}$ A variety of new women's organisations also emerged during this period, and women campaigned on a variety of diverse issues, including the need for women police officers and jurors, married women's nationality, and maternal health. ${ }^{36}$ While New Zealand women obtained the vote in 1893, they were not able to become members of parliament until 1919. Getting a woman elected to parliament was therefore another of the priorities of the 1920s, and several women stood unsuccessfully until Elizabeth McCombs won the seat for Lyttelton in a 1933 byelection. Despite these developments, studies of gender in interwar New Zealand often depict it as a society with rigid and limiting gender roles in which women were increasingly viewed in opposition to the male breadwinner. Jock Phillips identifies the 1920s onwards as era of the 'family man', but argues that hidden behind this ideal was a culture of misogyny and male resentment. ${ }^{37}$ But while men found escape in the male dominated world of the pub and the rugby field, women were tied to home and hearth. Erik Olssen's work on the Dunedin suburb of Caversham does acknowledge the role young women played in the work force, and identifies the early twentieth century as a period of widening opportunity for female workers. ${ }^{38}$ However, he too views the breadwinner

\footnotetext{
35 Dorothy Page, The National Council of Women: A Centennial History (Auckland: Auckland University Press, 1996), pp. 51-81.

36 Charlotte Macdonald, The Vote, the Pill and the Demon Drink: A History of Feminist Writing in New Zealand, 1869-1993 (Wellington: Bridget Williams Books, 1993), pp. 89-94; Dorothy Page, 'Women and Nationality: Feminist Organisations in the Inter-War Period', in Barbara Brooks, Charlotte Macdonald and Margaret Tennant (eds.), Women in History: Essays on European Women in New Zealand (Wellington: Allen \& Unwin, 1986), pp. 157-175.

${ }^{37}$ Jock Phillips, A Man's Country? The Image of the Pakeha Male: A History (Auckland: Penguin, 1987), pp. 221-260.

38 Erik Olssen, Building the New World: Work, Politics and Society in Caversham, 1880s-1920s (Auckland: Auckland University Press, 1995), pp. 70-95; Erik Olssen 'Working Gender, Gendering Work: Occupational Change and Continuity in Southern Dunedin' in Barbara Brookes, Annabel Cooper and Robin Law (ed.), Sites of Gender: Women, Men \& Modernity in Southern Dunedin (Auckland: Auckland University Press, 2003), pp. 40-90.
} 
ideal as paramount, and argues that few women viewed these careers as more than temporary detours on their path to marriage and children. ${ }^{39}$

The licentious flapper may be less obvious within New Zealand, but that does not mean that the modern woman was entirely absent. Danielle Sprecher finds the 'modern girl' in the New Zealand office, arguing that a modern appearance was considered an important component to success in the workforce.40 Charlotte Macdonald's Strong, Beautiful and Modern looks at national fitness campaigns in New Zealand and abroad and argues that the women and girls who participated were seen as modern through the possession of an active, healthy body. ${ }^{41}$ This emphasis on the modern body is also highlighted by Caroline Daley, whose discussion of beauty contests in New Zealand describes competitors with many recognisable 'modern girl' attributes. ${ }^{42}$ Charlotte Greenhalgh has suggested that the films played in New Zealand cinemas offered viewers of both sexes more diverse role models for the performance of gender, and argues that "histories that characterize the inter-war years as dull, conformist and hard do not give a full picture of people's lives, especially the lives of the young". 43 However, the dangers of modern life were also present, as Bronwyn Dalley's discussion of the death of Elsie Walker demonstrates. In 1928 seventeen year old Elsie Walker disappeared from the rural home of her aunt and uncle, where she worked as a domestic help. Her body, along with the family car, was discovered days later in Auckland, a town Elsie had long dreamed of visiting. The disappearance of a domestic worker from rural New Zealand might not be quite as thrilling as some of the scandals described in Bland's work, but in New Zealand the death of Elsie Walker commanded just as much press interest, and Dalley argues that "Elsie's pathetic and unsolved death

\footnotetext{
39 Olssen, Building the New World, pp. 227-228.

${ }^{40}$ Sprecher, pp. 141-162.

${ }^{41}$ Charlotte Macdonald, Strong, Beautiful and Modern: National Fitness in Britain, New Zealand, Australia and Canada, 1935-1960 (Wellington: Bridget Williams Books, 2011).

42 Caroline Daley, Leisure and Pleasure: Reshaping and Revealing the New Zealand Body, 19001960 (Auckland: Auckland University Press, 2003), pp. 103-115.

43 Charlotte Greenhalgh, 'Bush Cinderellas: Young New Zealanders and Romance at the Movies, 1919-1939', New Zealand Journal of History, Vol. 44, No. 1, 2010, p. 17.
} 
stood as a warning of what could await the innocent when they left the security of their domestic rural hearths to seek out the city". ${ }^{4}$

These works demonstrate that questions about modernity and women's place within it were being raised in New Zealand, just as they were elsewhere. A study of The Mirror has the potential to expand these ideas, containing as it does a slightly different vision of women in interwar New Zealand from that which dominates the historiography. The Mirror took women's careers seriously, with regular updates on women's success in business. Its readers were prompted to consider such careers for themselves, and women's pursuit of further education was celebrated. They were encouraged to drive and play sport. The magazine frequently engaged in political debate, and discussions around controversial topics like divorce and sex education. These articles ran alongside content with a more domestic focus - columns on mothercraft, recipes and patterns, and other advice for the modern housewife - belying the idea that domestic women could not also engage with the modern world. The Mirror presented an image of modern New Zealand in which women's lives were being expanded and improved.

The Mirror provides a link between New Zealand women and an international modernity. Its various contents helped to disseminate global images of modern femininity. Fashion pages described the latest fashions in Paris, while social pages reported on the activities of the royal family and Hollywood film stars. Many of the articles it published were purchased from overseas magazines, both English and American. Advertisements for Elizabeth Arden cosmetics and Ford motor cars linked New Zealand women to growing global commodity chains. But The Mirror also located the modern women within New Zealand, and it was The Mirror's local content which made it stand out from the other magazines which were available to New Zealand women at the time. It saw the

\footnotetext{
44 Bronwyn Dalley, 'The Cultural Remains of Elsie Walker', in Bronwyn Dalley and Bronwyn Labrum (eds.) Fragments: New Zealand Social and Cultural History (Auckland: Auckland University Press, 2000), p. 154.
} 
modern woman driving along New Zealand's scenic highways, sunbathing at the beach, or working in an Auckland office. The Mirror contains some travel content, and frequent too are articles reflecting on foreign societies - the state of women in Turkey, for instance. These articles reflect a keen interest in the world outside New Zealand, but they are often also used as opportunities to consider what makes New Zealand different or the same. The Mirror looks out at the world, mapping a global space, but it is also carefully positioning New Zealand and New Zealanders within that space.

Consumption was a key element of the modern world found in The Mirror. The magazine appeared during an era of booming consumption, where the wealth of goods on offer was rivalled only by the sophistication of the techniques used to sell them. This was the heyday of the department store and the beginning of scientific marketing. But consumption was not only modern, it was also gendered. Women were responsible for most household shopping, from clothes to groceries. The department store, with its tea-rooms and mannequin displays, was a space that catered primarily to women, and its emergence in the late nineteenth century helped to carve out a respectable public space for women in the modern metropolis. ${ }^{45}$ The modern woman was fashioned by her use of these consumer goods. As the Modern Girl Around the World Research Group have pointed out, advertisements played a key role in transmitting the image of their 'modern girl' around the globe, and she is identified by her use of specific products, particularly cosmetics. ${ }^{46}$ New Zealand's urban centres may have lagged slightly behind London, Paris or New York, but work by Helen Laurenson and Evan Roberts indicates that while New Zealand department stores did not

\footnotetext{
45 Mica Nava, 'Modernity's Disavowal: Women, the City, and the Department Store', in Mica Nava and Alan O'Shea (eds.), Modern Times: Reflections on a Century of English Modernity (London: Routledge, 1996), pp. 146-156; Erika Diane Rappaport, Shopping for Pleasure: Women in the Making of London's West End (Princeton: Princeton University Press, 2000), pp. 143-144, 159170; Elizabeth Wilson, Adorned in Dreams, revised ed. (London: I.B. Tauris, 2003), p. 150. 46 Modern Girl Around the World Research Group, "The Modern Girl Around the World: Cosmetics Advertising and the Politics of Race and Style', in The Modern Girl Around the World Research Group, The Modern Girl Around the World: Consumption, Modernity, and Globalisation (Durham: Duke University Press, 2008), pp. 25-54.
} 
operate on the same scale as their American or English counterparts, they were increasingly becoming central to New Zealanders' shopping experience. ${ }^{47}$ Magazines like The Mirror were an important component of this new consumer world. Not only was The Mirror itself a consumer product, purchased by readers throughout New Zealand, but the many advertisements it contained made visible a modern world of consumer goods, manufactured at home and abroad and available for purchase at Ballantynes, Kirkcaldie \& Stains, or the local branch of the Farmer's Trading Company.

It is important to note that The Mirror provides a picture of modernity in New Zealand that is distinctly middle class. Its discussions of women's work are usually couched in terms of personal interest or public contribution, rather than financial necessity. The problems of the poor are occasionally acknowledged, but generally in a paternalistic manner, as issues for The Mirror's middle-class reader to help solve rather than experience. Hamilton describes The Mirror's target audience as fairly broad, "ranging from the affluent middle class woman with income to spend on fashionable clothing, to the reader concerned with the day to ray running of the household, although it should be recognised that these were often the one and the same individual". ${ }^{48}$ I would go further, and argue that The Mirror often actively constructed them as one and the same. The Mirror's discussion of class is complicated by the belief, common at the time, that New Zealand was a particularly egalitarian society and lacked either a very rich or an extreme poor. ${ }^{49}$ The degree to which this is true is still argued over by historians today, but in The Mirror it was unquestioned. The result was a slightly contradictory discourse around class in which The Mirror could claim to be read "in the best homes of the land" and yet praise New Zealanders' "scorn

47 Helen B. Laurenson, Going Up, Going Down: The Rise and Fall of the Department Store (Auckland: Auckland University Press, 2005); Evan Roberts, "'Don't Sell Things, Sell Effects": Overseas Influences in New Zealand Department Stores, 1909-1956', Business History Review, Vol. 77, No. 2, 2003, pp. 265-289.

${ }^{48}$ Hamilton, 'Periodicals of Literary Interest', p. 450.

${ }^{49}$ Erik Olssen, Clyde Griffen and Frank Jones, An Accidental Utopia? Social Mobility and the Foundations of an Egalitarian Society, 1880-1940 (Dunedin: Otago University Press, 2011), p. 20. 
for pandering to social rank or hereditary distinctions". ${ }^{50}$ Generally The Mirror was a predominately middle-class magazine and as such mainly reflects middle class preoccupations, but it often assumed those preoccupations to be universal.

The modern woman of The Mirror is also, generally, white. Stephen Hamilton has studied the depiction of Māori in The Mirror, and he finds that the magazine primarily featured Māori as 'types' rather than individuals, nameless figures dressed in traditional clothing and presented as ethnographical curiosities. $\mathrm{He}$ argues that by publishing these images, The Mirror "contributed to an effective erasure from the consciousness (and conscience) of mainstream middle-class Pākehā of the complex reality of Māori in late colonial New Zealand". ${ }^{1}$ Māori are assumed to be outside modernity, to be encountered perhaps, on a holiday to Rotorua, but not found in the modern world. There is, however, one exception which Hamilton does not discuss. Lady Maria Pomare was the wife of Sir Maui Pomare, a prominent Māori doctor and, during the decade of this study, Minister of Native Affairs and of Health. Lady Pomare features regularly in The Mirror's social pages, listed amongst New Zealand's other social elites and charitable benefactresses. In July 1923 The Mirror published a full-page portrait of Lady Pomare, an image that differs little from the regularly published photographs of New Zealand statesmen and their wives. ${ }^{52}$ Lady Pomare's Māori identity is not commented on and it seems likely that there may have been other less known Māori women who feature in The Mirror whose Māori identity is rendered entirely invisible. In The Mirror Māori appear either as relics of the past or integrated members of Pākehā society; the possibility that Māori could engage with the modern world on their own terms is generally ignored.

The first chapter of this thesis looks at the different content of The Mirror, exploring the idea of the magazine as a 'space for women'. The Mirror was New

50 The Mirror, November 1929, p. 50; 'In the Mirror', The Mirror, February 1927, p. 6.

${ }^{51}$ Stephen Hamilton, 'Reflecting Ourselves: "Maoriland" in the Mirror', Journal of New Zealand Studies, Vol. 8, No. 1, March 1998, p. 15.

52 'Lady Maui Pomare, O.B.E. and Wife of Sir Maui Pomare, Minster for Native Affairs', The Ladies' Mirror, July 1923, p. 2. 
Zealand's first women's magazine, and it was unique in its wide range of content written primarily with women in mind. Diverse editorial features, short stories and local news appeared alongside a rich visual presentation of fashion plates, social portraits and carefully placed advertisements. It treated women's public contributions and their domestic concerns with equal weight, catering to the modern woman who was capable of a range of interests.

The Mirror was a space for the modern woman, but the modern woman of the 1920s could often be a controversial figure. This was particularly true of the young unmarried 'modern girl', who appeared to represent a radical revolution in feminine appearance and behaviour since her mother was a girl. The second chapter focuses on this often unsettling and always hotly debated figure of modern femininity. The Mirror, like most other publications of the day, participated in the debate surrounding the modern girl. While it condemned the cocktail swilling flapper, it often argued she was overrepresented in the public discourse. Instead, The Mirror generally chose to focus on the healthy and athletic 'girl of today'.

Modernity was not constrained to young women, however. Mothers and wives could be modern too, as The Mirror's more domestic content illustrated. The magazine gave readers detailed advice on maintaining a well ordered home, from decorating tips to recipes and cleaning advice. The women's magazine's emphasis on the domestic is often seen as one of its most prescriptive elements, and its inclusion prompted Hamilton's characterisation of The Mirror as conservative and overly invested in women's "traditional role of mothers and wives". 53 However, women's domestic role was itself subject to modernisation. While the housewife who presides over a gleaming kitchen in the suburbs may today seem like an icon of conservatism, in the eyes of The Mirror she was startlingly modern. The third chapter will explore how The Mirror helped women navigate the changing world inside their own homes.

${ }^{53}$ Hamilton, 'Periodicals of Literary Interest', p. 449. 
Royal news is one of the key features of a women's magazine, and The Mirror was no exception. Pictures of the royal family graced the cover on a regular basis, and articles by anonymous 'palace insiders' promised the reader intimate knowledge about their real personalities. The Mirror's coverage of the royal family reached fever pitch in 1927, when the Duke and Duchess of York visited New Zealand. This celebration of royalty can be seen as one of the more stuffy and conservative elements of the women's magazine, but its inclusion within The Mirror, a magazine which generally strived to be modern, raises questions about what the royal family represented to New Zealanders in the interwar period. The fourth chapter explores these questions, discussing the relationship that appears between modernity, royalty, and a changing empire in The Mirror's coverage of the 1927 royal tour.

These chapters use The Mirror to explore very different aspects of New Zealand women's relationship with modernity, exposing the diversity of the magazine's content. Heterogeneity is a key feature of the magazine format. The Mirror was made up of multiple articles by multiple authors, many of which may well have been originally published in an entirely different magazine, written for American or English audiences. As a result, the same issue could easily accommodate competing ideals. Neither Hamilton nor Corbitt are entirely wrong in their characterisations of The Mirror. It did support housewives, it did encourage consumption. But it also at times supported alternate visions of modern femininity: women who were content to stay single and childless, career women, women who sought world peace and political power. It could argue one month that women's primary duty was to their home and their children and women's tendency to abandon them was the cause of all that was wrong with modern society; the next month it would argue that society could not progress unless women expanded their efforts beyond the domestic sphere.

These competing images do not fit neatly into some kind of coherent whole, The Mirror endorsed model of modern femininity. Instead, The Mirror provided a range of models. The advice given to readers by the magazine was at times conflicting, but the result was that what it offered was a variety of paths to take. Some of these paths went in directions unexpected; they strayed from that 
which many New Zealand historians have mapped out for women of the period. The Mirror celebrated motherhood and the well organised home, but it also celebrated women doctors and lawyers. Ros Ballaster et al have suggested that we speak of multitudes rather than contradictions when considering the models of femininity supplied by the woman's magazine. ${ }^{54}$ The Mirror suggests a multitude of opportunities - or perhaps, more accurately, a multitude of aspirations - for New Zealand women.

54 Ballaster et al, p. 12. 


\section{1.}

\section{A Space for Women}

The very first issue of The Mirror contained an article on the Auckland Women's Club. Filled with glowing descriptions of tasteful décor and accompanied by pictures of comfortable sitting rooms and well-stocked bookcases, the article described what was, quite literally, a space for women. But more than just a physical space, the Mirror stressed the Club's function as a much needed place for women to come together to share ideas and accomplish common goals:

The woman lawyer, the woman doctor, the budding stateswoman, the stenographer, the business woman, the literary woman, the journalist and the philanthropist - all meet here on common ground for the interchange of ideas. And mingling with these, delighting her soul with the freshness of the broad outlook upon life that pervades the Club atmosphere, is the gentle housewifely woman, who finds here a mental tonic and a new inspiration. ${ }^{55}$

The Mirror saw itself as a similar kind of space for women. While not a physical space, The Mirror too sought to provide New Zealand women with their own place to share ideas, whether cooking tips or public health strategies. The Mirror kept its readers informed on social issues and the latest fashions; it provided advice on raising children or starting a career. It connected them with happenings around the country, back 'home' in Britain, and celebrity gossip in Hollywood. It too was richly decorated, with images of picturesque landscapes and social portraits. It invited readers to contribute, inviting their family snapshots and poetry for publication. And it was a space, like the Auckland Women's Club, where the housewife could mingle with the career woman.

The Mirror was notable as the first such space for women in print in New Zealand. The majority of existing periodical content aimed at women was to be 
found in the ladies' pages of local newspapers. While these pages were largely dominated by social notes and household tips, Chanel Hughes' study of the Canterbury Times 'Ladies' Page' has shown that these spaces could contain more complex gender politics than might be expected. Under the helm of Dolce Cabot as editor from 1894-1907, the Ladies' Page allowed a degree of support for the women's movement while still adhering to dominant middle-class ideology surrounding 'womanliness' and separate spheres. However, Hughes is careful to attest that Cabot's 'Ladies' Page' was unusual amongst women's columns of its period, which largely stuck to social gossip and fashion. ${ }^{56}$ A handful of women-aimed periodicals had appeared in the 1890s: Daybreak, White Ribbon, and the New Zealand Graphic and Ladies' Journal. Daybreak and White Ribbon were both allied to women's political movements rather than being general women's interest papers. Daybreak did not last long, folding in 1896 after less than a year in print. White Ribbon continued well into the twentieth century, and was published concurrently with The Mirror for almost twenty years. However, its purpose as a mouthpiece for the women's movement and its close ties to both the National Council of Women and the Women's Christian Temperance Union distinguished it from The Mirror and other commercial women's magazines. It was primarily motivated by feminist concerns rather than entrepreneurial ones, seeking to engage and connect an organisational membership. The New Zealand Graphic and Ladies' Journal was slightly different. It was a commercial illustrated weekly aimed at a more general audience; a 'ladies' journal', in that it included social gossip, fashion notes and serialised fiction, but also featured a wide array of photographic content. ${ }^{57}$ This brief flourish of women's publications was, however, short lived. The New Zealand Graphic ceased publication in 1908, meaning that at the time of The Mirror's first publication in 1922, White Ribbon was the only other New Zealand women's journal available.

${ }^{56}$ Hughes, p. 111.

57 Tye, p. 216. 
The paucity of women's media from within New Zealand was supplemented by a wide array of imported magazines. Newsagents around the country advertised their wide range of imported American and English publications, including Queen, The Ladies' Home Journal, and all the latest 'fashion journals'. New Zealand's public libraries generally stocked a similar range of magazines, and 'ladies' often had their own designated tables in many of their reading rooms. ${ }^{58}$ According to Susann Liebich, these libraries acted as "nodes in local and global webs of reading", connecting the New Zealand reader to an international community. ${ }^{59}$ However, while the Auckland Library assured the public that they made their periodicals available "at the earliest possible moment"; there was an inevitable delay in acquiring magazines printed on the other side of the world. 60 The Mirror itself commented in August 1923 that the illustrated papers containing the pictures from the Duke of York's April wedding had only just arrived. ${ }^{61}$ Additionally, while these imported magazines could help New Zealand women keep somewhat abreast of news and fashions abroad, they offered little in terms of local content.

It was into this gap that The Mirror stepped, creating a space for New Zealand women within the local print culture. It provided readers with all the content expected in a women's magazine, but within a recognisable New Zealand context. Its social pages discussed the activities of prominent New Zealanders. Discussion of social issues like public health or sex education connected to wider international debates, but in The Mirror, they could be considered with regard to local specifics. The Mirror also engaged with the wider world. Much of its content was purchased from outside magazines, and the news from abroad was printed alongside that from within New Zealand. It also suggested that its content could be of interest to readers outside New Zealand, encouraging readers to send copies of the magazine to friends and relatives

\footnotetext{
58 Liebich, pp. 80-81.

${ }^{59}$ Liebich, p. 65

${ }^{60}$ John Barr, Chief Librarian, 'Auckland Library: Official Figures for Magazines', Auckland Star, 4 March 1930, p. 6.

61 'In the Mirror', The Ladies' Mirror, August 1923, p. 4.
} 
overseas, and detailing where the magazine could be purchased in London. If New Zealand readers were part of a 'global web of reading', then The Mirror emphasised that they could transmit as well as receive.

What kind of women's magazine was The Mirror? Cynthia White suggests that that there exists a parallel between the amount of domestic content and the status of the magazine: "as a general rule, the lower the class of readership, the more home-centred a magazine's contents tended to be".62 While elite magazines "catered to the more socially conscious and serious-minded women" by reporting on women's public activities, parliamentary proceedings, and charitable concerns, lower middle-class magazines were almost entirely focused on the reader's domestic concerns. The Mirror certainly aspired to be seen as a high quality home journal. Reports on the League of Nations or the work of women in other nations provided fodder for the politically engaged reader, while opinion pieces prompted engagement with social issues like public health reform. Features on both classical musicians and artists spoke to the culturally minded, as did the magazine's regular literary review column. Its own advertisements declared that "The Mirror is a necessity to people of refinement" and that "The Mirror is looked forward to in the best homes of the land". 63 However, the glamour of The Mirror's glossy photo spreads and its intellectual discussions of international politics are tempered by content not usually found in the highbrow magazines it emulated, and in reality, The Mirror probably had a much broader audience. The Mirror's knitting patterns, economical recipes and romance stories all hint at a slightly less exclusive readership, indicating that while The Mirror may well have been read in the best homes in the land', it could also be found in those of the more middling sort.

Margaret Beetham draws attention to Woman, a slightly different kind of women's magazine which might be useful for considering where The Mirror fits

62 White, p. 82.

63 The Mirror, November 1929, pp. 30, 50. 
in the taxonomy of the women's press. Woman was addressed to modern women "who want something more than the 'lady's' or 'society' paper or cookery book and something less than the ponderous daily leader... or the academic weekly or monthly review". ${ }^{64}$ Beetham studies Woman in the 1890 s, but the moderate progressivism she identifies within it looks remarkably similar to much of The Mirror's content, catering to the educated female reader while still advocating the importance of domesticity in women's lives.

These international comparisons are useful, but they do have their limits. The Mirror operated within very different context from British magazines, in which there was a much smaller pool of readers but also far fewer competitors. The small size of New Zealand probably made seeking a fairly broad audience necessary, but the lack of local competitors also meant that the hierarchy of magazines that White identifies within the British women's press was not so important. As the first and only women's magazine in New Zealand, The Mirror could create its own formula, establishing new, local standards for the women's press. That said, The Mirror did reach out to a small number of international readers, and it frequently expressed the hope that it would meet their expectations of a 'quality journal'.

The Mirror's space did not remain static over time, and its multiple changes in title are an indicator of its shifts. Initially called The Ladies' Mirror: The Fashionable Ladies' Journal of New Zealand, it was by the end of its first decade The Mirror: The Home Journal of New Zealand. The 'Ladies' was dropped from the main title without fanfare in February 1926, but the changes the subtitle underwent were less straightforward. The cover proclaimed the magazine to be 'The Home Journal of New Zealand' from October 1923, but it was still 'The Fashionable Ladies' Journal of New Zealand' on the inside title page until March 1925. Then it was The Ladies' Mirror: The Home Journal of New Zealand, "in which is incorporated 'The Home Journal of New Zealand,' 'The Fashionable 
Ladies' Journal of New Zealand' and 'The Ladies' Mirror Motoring Supplement'”. A year later it was The Mirror: The Home Journal of New Zealand, "in which is incorporated 'The Ladies' Mirror' and 'The Woman's Mirror'", although where 'The Woman's Mirror' comes from is unclear. It was not until May 1928 that it abandoned these subtitles, settling finally on The Mirror: The Home Journal of New Zealand. The decision to drop the designation of 'Ladies', from the magazine's title and the increasing emphasis on home rather than fashion could be indicative of several different things. Stephen Hamilton suggests that it is a result of editors wanting to distance themselves from the limitations of a women's magazine, instead becoming a family magazine of more general appeal.65 It is possible that this is part of it, although the magazine was still undeniably female focused long after the name change. Another possibility was that The Mirror wanted to escape the other connotations that come with identifying as a 'ladies' magazine - an upper-class exclusivity that may have been losing its appeal. It is possible that the magazine, while initially attempting to position itself as a high-brow upper middle-class magazine was, by 1926, seeking a slightly more general and democratic audience.

The Mirror put a lot of pride in its illustrations. Sally Stein argues that in the twentieth century the women's magazine "was becoming a predominantly visual experience", something to be viewed as well as read.66 This is clear in The Mirror, which was a highly visual magazine regularly containing photographs of New Zealand's best homes and gardens, scenic views, and New Zealanders of note. The magazine held snapshot competitions, and encouraged readers to send in pictures they thought might be of interest. Many of the extra pages in the December holiday issues were comprised of reader pictures. Most of the pictures included in the magazine were social portraits: public figures, but also readers and their children, debutantes, wedding parties, and female

${ }^{65}$ Hamilton, 'Periodicals of Literary Interest', p. 450-452.

${ }^{66}$ Sally Stein 'The Graphic Ordering of Desire: Modernization of a Middle-Class Women's Magazine, 1919-1939', in Richard Bolton (ed.), The Contest of Meaning: Critical Histories of Photography (Cambridge: MIT Press, 1989), p. 146. 
graduates in academic dress. Picturesque views of New Zealand landscapes also featured heavily. The Mirror was particularly proud of these images: "The Mirror owes its remarkable success and popularity in no small measure to the beauty and artistry of its illustrated sections". ${ }^{67}$ It seems they were right; a survey conducted in 1931 determined the magazine's 'art pages' to be the readers' favourite feature. ${ }^{68}$ These illustrations were considered notable not only for their beauty, but because they demonstrated the magazines' advanced print quality. In the eyes of The Mirror's producers, its images were an important part of what made it a modern, quality journal.

The Mirror, as its title might suggest, also contained a wide array of fashion and beauty advice. 'Vanitas Vanitatum', the fashion column, contained descriptions of the current fashions and predictions for the future, alongside extensive illustrations. 'Yvonne', The Mirror's special correspondent, sent back the latest fashion news from Paris. Articles like 'The Importance of Line in Fashion' explained to readers how to identify their body shape and then how to dress it appropriately. ${ }^{69}$ Others suggested how best to invest their dress budget. The Mirror's beauty column provided tips for a variety of problems, instructing readers on how to maintain a clear complexion or slim ankles, and gave advice on the tasteful application of make-up. These sections helped The Mirror reader 'look the part' of the modern woman.

Less glamorous, but still substantial, was The Mirror's domestic content. Every issue contained recipes and cooking tips, as well as 'household hints', mostly cleaning advice like stain removal or the best approach to spring cleaning. Knitting and crochet patterns also appeared, although less regularly. Articles like 'The Bride's First Dinner Party', and 'How to Give a Bridge Luncheon' gave advice on hosting successful social events, suggesting both a menu and table-

\footnotetext{
${ }^{67}$ Advertisement, The Mirror, November 1927, p. 27.

68 'Results of "Most Popular Feature" Competition', The Mirror, September 1931, p. 35.

69 'The Importance of Line in Dress', The Mirror, October 1926, pp. 22-24, 26
} 
settings. ${ }^{70}$ The magazine also provided advice and reassurance to mothers. The 'mothercraft' column advised readers on the unique challenges of raising children at various ages, from colicky babies to disobedient adolescents. Articles like 'What to Tell Your Daughter' addressed slightly more thorny issues, such as how to talk to your child about sex. ${ }^{71}$ Others expressed concern about the welfare of New Zealand's children more generally, and discussed the efforts of organisations like Plunket to improve it. Much of the domestic content could be highly scientific, advocating modern approaches to household tasks. 'Lessons in Food Values' taught readers how to plan healthy meals for their families by explaining the basic scientific principles of nutrition. ${ }^{72}$ 'A Kitchen Planned by a Woman', suggested the most efficient ways of organising a kitchen, complete with architectural diagrams. ${ }^{73}$ In 1928 Melanie S. Primmer took over as editor of the regular 'In the Kitchen' section. Primmer was the author of The Up-ToDate Housewife, a book aimed at the New Zealand housewife attempting to run a family without domestic help. Her status as a professional authority on home cooking and her B.A. degree was proudly acknowledged in the byline each month. 'Economical' recipes and articles like 'If You Can't Afford a Refrigerator' provided cost-cutting tips to the home on a budget.

Short stories featured in many issues, particularly the holiday issues. Occasionally they were serialised; more often they were stand-alone stories. While the majority appear to have been purchased from overseas publications several of them were contributed by readers and local writers and were set in New Zealand. 'When the Pohutukawa Bloomed: A New Zealand Christmas Story', for example, is a romance set on a New Zealand farm in which the day is

\footnotetext{
70 'The Bride's First Dinner Party', The Ladies' Mirror, May 1924, pp. 46-47; Louise May Ambrose, 'How to Give a Bridge Luncheon', The Mirror, July 1928, p. 78.

71 Bernarr MacFadden, 'What to Tell Your Daughter', The Ladies' Mirror, May 1928, pp. 14-15, 19.

72 'Lessons in Food Values', The Mirror, September 1926, pp. 60-61, 64, 69

73 Miss F. I Field, The Ladies' Mirror, November 1923, 'A Kitchen Planned By A Woman', pp. 20 21.
} 
saved when treasure buried during the Māori Land Wars is rediscovered..$^{74}$ Most of these stories are romances, but not all. 'Daphne Engaged', is the story of Daphne, a (relatively young) maiden aunt who, fed up with a life of boredom and drudgery, runs off with one of the male friends of her nieces. However, it turns out this young man is a film director, and instead of being engaged to be married, Daphne is engaged to star in his latest film. ${ }^{75}$ Daphne takes her life into her own hands and is rewarded with success as a film star, a fate viewed by her jealous nieces as much more exciting than marriage. The plucky, independent heroine was common, even if she did usually end up finding love.

Local news was transmitted through The Mirror's regional columns. Each of the city centres had their own column, beginning with Auckland, Wellington and Christchurch, and eventually expanding to also include smaller centres like New Plymouth and Hamilton. These columns relayed the news from the area, detailing significant social events, important visitors, and the activities of local women's clubs and organisations. The Mirror also published engagement and wedding notices for the country as a whole. Not only did these features allow readers to see their own local news in print, they connected groups of women across the country. Christchurch women could read about the activities of the Auckland Women's Club, both could hear about the women in Wellington. These columns are, however, predominantly urban in their concerns. The Mirror covered the activities of a broad range of different women's groups; alongside the Auckland Women's Club are articles on the National Council of Women, Plunket, the YWCA and the Victoria League. Noticeably absent is any coverage of rural women's organisations, like the Country Women's Institute or the Women's Division of the New Zealand Farmers' Union (later the Women's Division of Federated Farmers), both of which were formed in the 1920s and were influential women's organisations of the interwar period and beyond.

\footnotetext{
${ }^{74}$ Isabel M. Peacocke, 'When the Pohutukawa Bloomed: A New Zealand Christmas Story', The Ladies' Mirror, December 1923, pp. 21-22.

75 Esther Glen, 'Daphne Engaged', The Ladies' Mirror, September 1923, pp. 10, 20, 48.
} 
Perhaps one of The Mirror's most interesting features was its motoring section. It started out in The Mirror's early issues as the 'Women and Her Car' column, written by an anonymous 'Sparking Plug'. This column was specifically written for the female motorist, and combined confidence in her abilities - "The modern car requires no attention that is beyond the strength of a normally healthy woman" - with an acknowledgement that she might have specific, feminine concerns - "If driving a car is not 'second nature,' never attempt 'speeding,' for you are bound to get a strained anxious expression, which will print indelible lines upon your face". ${ }^{76}$ Practical driving and car maintenance advice is supplemented with tips on removing grease stains and the selection of appropriate driving wear. The motorcar was at this time a powerful symbol of modernity, associated with progress and mobility. ${ }^{77}$ In aligning women with driving, The Mirror presented women as actively involved in the modern world. However, this association was short lived. In 1924, the column was expanded into a multipage 'motoring supplement', which contained a wide variety of motoring content: discussion of new models, common mechanical issues, proposed motoring regulations, and suggestions for motoring tours were all laid out next to multiple car advertisements. While longer than the original column, it no longer assumed a specifically female audience. Occasional articles discussed or advised the woman driver, but generally the Mirror's motoring section addressed a gender neutral or even male audience.

In addition to the motoring supplement, The Mirror included a few other sections that may have been considered of interest to readers other than women. Stephen Hamilton argues that the Mirror quickly turned itself into a family magazine rather than a women's magazine, and it is true that it often claimed to have 'something for everyone'. 'Uncle Ben's Sunshine Circle' had stories and puzzles for children. There was a 'Fashion for Men' column, as well

76 Sparking Plug, 'Woman and Her Car', The Ladies' Mirror, January 1923, p. 42.

77 John William Knott, 'The 'Conquering Car': Technology, Symbolism and the Motorisation of Australia before World War II', Australian Historical Studies, Vol. 31, No. 114, pp. 7-12; Georgine Clarsen, Eat My Dust: Early Woman Motorists (Baltimore: Johns Hopkins University Press, 2008), p. 5-7. 
as columns that could be intended for a male audience. One regularly occurring column was 'Our Club Room Lounge', in which the author, 'Scribbler' discussed the issues of the day through the (presumably made-up) conversations overheard in the lounge of his men's club, presenting the opinions of a lawyer, a major, and a priest, amongst others. However, in 1928, The Mirror was still pronouncing itself to be "the brightest publication devoted primarily to the interests of women".78 Few articles would not have had some appeal to women. A men's fashion column could be read by a man, but it would also be of interest to the woman who helps her husband choose the clothes he buys. Scribbler's column offers not only an authoritative perspective on current events, but also an insight into the masculine world of the men's club. And while the text of the motoring supplement only occasionally acknowledges female drivers, the advertisements that accompany it tell another story, with cars specifically marketed at women featuring heavily. The female driver might have disappeared from the content of the Mirror's motoring supplement, but she still was very much present in its advertisements. There may have been something in there for everyone, but women remained the primary targets.

The Mirror was also a space for women as consumers. Most obviously, women consumed the magazine, exchanging their shilling for the pleasure of reading and looking at its pages. But not only was The Mirror itself a product to be consumed by the reader, it also invited the reader into a broader world of consumption. Advertisements were an important part of the visual landscape of the magazine, and as readers perused The Mirror they encountered advertisements for cosmetics, household appliances, clothing, baby formula, cars and even electricity. The Mirror described itself as "the salesman that lives in over 20,000 homes", and pledged its ability to sell goods "as long as the pages hold together". ${ }^{79}$ The Mirror's position as a space for women was not tangential to its commercial influence. It was women who were the decision makers when

\footnotetext{
78 Advertisement, The Mirror, November 1927, p. 27.

79 The Mirror, June 1930, pp. 23, 32.
} 
it came to shopping for most families, and The Mirror was acutely aware of this. Its appeals to advertisers stressed the importance of the female market and the magazine's power to reach her: "An advertisement has far greater value if seen by readers who are likely buyers. 'The Mirror' appeals to women householders, who buy, it is conservatively estimated, 85 per cent. of the world's commodities".80 Even when they were not the intended consumer, women could still hold sway, as The Mirror attested when it quoted a tailor who claimed that women "directly or indirectly" influenced nine out of ten men's suit sales. ${ }^{81}$ Women held a lot of power in the modern world of consumption, and The Mirror, as a magazine that appealed to women, was an important outlet for advertisers.

The position of these advertisements was strategic, with The Mirror's pages carefully arranged to make them harder to ignore. Articles started in the beginning of the magazine, where few advertisements were printed, but were nearly always concluded towards the back of the magazine, where advertisements were much more dense, making it impossible to avoid them completely. Sally Stein has identified the development of a similar pattern in issues of The Ladies' Home Journal from the same era, and she argues that the forced flicking back and forth through the magazine served as a form of "entrapment", forcing the reader to view parts of the magazine they might otherwise ignore, including advertisements. ${ }^{82}$ The Mirror itself noted the importance of placing advertisements next to articles. In 'A Chat With Advertisers', it explained that "an advertisement placed next to reading matter is twice as effective as when it is surrounded by other advertising".83 This careful balance of advertisements to editorial content is itself highly modern; a much more calculated and sophisticated approach to selling. It mirrored the developments in marketing elsewhere, as businesses no longer simply catered

80 'Three Interesting Facts', The Mirror, April 1931, p. 81.

81 'From the Editor's Chair: A Chat With Advertisers', The Mirror, March 1930, p. 55.

82 Stein, pp. 149, 152-153.

83 'From the Editor's Chair: A Chat With Advertisers'. 
to customers' needs, they anticipated them, and increasingly, sought to dictate them. On the high street and in the department store, carefully curated window displays lured in customers and shop assistants trained in the art of selling convinced them to make a purchase. ${ }^{84}$ The Mirror's carefully organised advertisements were the print component of a wider trend towards modern 'scientific selling'.

Women's direct editorial involvement in the creation of The Mirror is hard to establish. The majority of content is unattributed, and early issues provided no indication as to who was in charge of the magazine, although an 'Editoress' is occasionally referenced. Articles that are attributed are fairly evenly balanced between male and female authors. Information about the behind the scenes of the magazine during the time period of this study is limited to the company files of the Mirror Publishing Company. First formed in 1922, with the purpose of publishing "an illustrated Ladies' newspaper", the company's initial ten shareholders included three women: Annabella Mary Geddes, Mary Goodwin and Sarah Clinkard. These women all had relatively small stakes, they all had male relatives also investing, and their occupations were all listed as married woman or householders. ${ }^{85}$ The degree of their input into the Mirror is hard to establish. This is unfortunate, as Annabella Mary Geddes was a woman of Māori heritage and considerable means with active involvement in a range of women's organisations. ${ }^{86}$ Understanding the nature of her influence on The Mirror would be interesting indeed.

Regardless, the involvement of these women seems to have been short-lived. In 1923 the original Mirror Publishing Company was dissolved and a new one

${ }^{84}$ Susan Porter Benson, Counter Cultures: Saleswomen, Managers and Customers in American Department Stores, 1890-1940 (Chicago: University of Illinois Press, 1988), pp. 101-116; Evan Roberts, pp. 278-287.

85 'Memorandum of Association of The Mirror Publishing Company', 4 ${ }^{\text {th }}$ April 1922, The Mirror Publishing Company Ltd Records, Box No. 404/2283:1922/24, R9094591, Archives New Zealand Auckland.

86 Sandra Coney, 'Geddes, Annabella Mary', Dictionary of New Zealand Biography, Vol. 4, 1996, http://www.teara.govt.nz/en/biographies/3g4/geddes-annabella-mary, accessed 13 December 2014. 
established, with shares evenly split between Alexander Geddes, Annabella's son and one of the initial shareholders, and Henry Joseph Kelliher, a man not previously involved with the company. Alexander Geddes retained his role as company director and substantial share owner until his death in 1936, but his involvement appears to be confined to the publishing company rather the magazine itself. Kelliher became managing director of The Mirror, with Otto Williams as editor, although Kelliher appears to have had substantial editorial involvement. In 1930 Kelliher officially took over as editor and soon after Williams left The Mirror to start the New Zealand Woman's Weekly. Kelliher remained in charge of the Mirror until it ceased publication in 1963.

Kelliher's business interests were not limited to The Mirror. His business career began with a smart investment in a hotel in Carterton, right on the edge of neighbouring Masterton's dry zone, and he continued to have interests in the liquor industry while involved in The Mirror. In 1930 he formed Dominion Breweries with W. J. Coutts, one of the nation's largest liquor companies, and continued to run both companies simultaneously. Kelliher was keenly interested in monetary reform, an interest which caused him to strike up a friendship with Arthur Field, one of New Zealand's most well-known right-wing political figures. Field even contributed to The Mirror, although not during the period of this study. R. C. J. Stone, who wrote Kelliher's entry in the Dictionary of New Zealand Biography, gives him credit for the magazine's progressive nature, arguing that it became apparent with his ownership and intensified when he took on the role of editor. ${ }^{87}$ In reality, one of the most notable differences with Kelliher at the helm was that the magazine stopped printing pleas for prohibition support and began printing liquor advertisements - not an insignificant move, considering New Zealand feminism's close ties with the Temperance movement and the fact that White Ribbon, New Zealand's only other women's publication, was run by the Women's Christian Temperance 
Union. It seems likely that Kelliher did have a substantial influence on the tone of the Mirror, but many of the progressive tendencies it had were already in place when Kelliher joined the company.

While editorial control of The Mirror appears to have been male dominated, it did provide space for women's voices through the publication of many of New Zealand's female writers. Isabel Maude Peacocke (later Cluett), a well-known New Zealand author, wrote both fiction and non-fiction for The Mirror. Jessie Mackay was an active member of both the Women's Christian Temperance Union and the National Council of Women and a contributor to White Ribbon as well as British feminist journals like Time and Tide. She wrote some of The Mirror's more serious feminist content, such as an article published in 1926, 'Family Endowment: The Economic Rights of the Mother \& Family', which argued that a government endowment for mothers would restore economic independence to women and make both them and their families better off. ${ }^{88}$

The Mirror aligned itself with the women's movement in its very first editorial. Its appearance coincided with a significant moment in international feminism, when women had recently obtained the vote in a host of countries, including Britain, the United States and Canada. Seen internationally as a sign of progress for the women's movement, in New Zealand this prompted slightly more sombre reflection. New Zealand women had had the vote since 1893, but these overseas successes forced local feminists to consider what they themselves had achieved in the intervening thirty years. The Mirror's first editorial made it clear it believed the answer was 'not much'. It argued that feminism in New Zealand, while starting strong, had since floundered, and the rest of the world had not only caught up, but passed us by:

The tide of feminism has rolled past us unheeding; from the crest we have steadily receded to the trough, and nations which regarded our

\footnotetext{
${ }^{88}$ Jessie Mackay, 'Family Endowment: The Economic Rights of the Mother \& Family', The Mirror, October 1926, p. 37.
} 
experiment of the 'eighties with distrust and alarm have badly distanced us in recognition of the claims of womankind. The sex has thus been left in the backwash here, very largely because it has remained without a rallying point - lacking a medium for the expression of the devices and desires of its heart, its claims have been foregone. That disability no longer exists, and with the appearance of The Ladies' Mirror woman becomes vocal, her views upon every question which impinges upon the orbit of her daily life will find expression here. ${ }^{89}$

In the eyes of The Mirror this floundering was the result of the lack of a forum for women. It presented itself as the solution, a space for women to make their voices heard.

Whether the Mirror entirely lived up to its initial claims to be the saviour of the New Zealand women's movement is debatable, but it certainly did continue to take an interest in women's political progress. It frequently reported on the work of a variety of women's organisations and was for a period the "Official Organ" of the New Zealand National Council of Women. Editorials and feature articles addressed some of the key women's issues of the day such as the question of married women's nationality, and from time to time the magazine published feminist interest pieces like those written by Jessie Mackay. The Mirror was particularly concerned with the need for more women to take on public roles. Numerous Mirror editorials deplored the lack of a single female Member of Parliament, and encouraged readers to get involved in politics and support female candidates. ${ }^{90}$ Nor did it feel women's involvement in public life should be limited to parliament - women had important roles to play on hospital boards, education boards, and charitable aid boards. They should have

89 'Editorial Reflections', The Ladies' Mirror, July 1922, p. 10.

90 'Editorial Reflections', The Ladies' Mirror, October 1922, p. 5; 'Editorial Reflections', The Ladies' Mirror, December 1922, p. 6; 'Editorial Reflections', The Mirror, July 1928, pp. 6-7. 
greater involvement in the justice system too; The Mirror advocated policewomen, female jurors, and justices of the peace.

Alongside this advocacy of woman's public role, The Mirror continued to emphasise the importance of her domestic one. After the opening editorial had made its case for the importance of the women's movement, it went on to acknowledge that “Woman's supreme and unchallenged domain is the home feminine art and grace have their abiding place here, and with its walls are mirrored the very soul of its chatelaine". ${ }^{91}$ It is this statement which caused Stephen Hamilton to argue in his survey of the Mirror that "the Mirror aligned itself with the conservative belief that women, who during the labour shortages occasioned by World War One had taken an unprecedented role in the work force, should now step back into their more traditional role of mothers and wives."92 The concept of the 'traditional role of mothers and wives' is itself not unworthy of interrogation, but particularly questionable is the suggestion that The Mirror's commitment to expanding woman's purview could be undermined entirely by acknowledging the continued importance of her domestic role. The Mirror claimed that in this new magazine, "the whole gamut of the activities of the sex will be run". ${ }^{93}$ Domestic concerns - cooking, home decorating, childrearing, knitting patterns - all of these things were of interest to most New Zealand women, and their inclusion alongside social and political commentary does not somehow depoliticise the other content. Unlike Hamilton, The Mirror did not seem to think that (moderate) feminism and domestic concerns were contradictory.

Nor is this view limited to The Mirror. Chanel Hughes has found a similar 'heterogeneity' at the heart of The Canterbury Times' 'Ladies' Page', and she goes so far as to argue that the inclusion of more traditional content made the radical more accessible to readers. She points out that most women did lead domestic

\footnotetext{
91'Editorial Reflections', The Ladies' Mirror, July 1922, p. 10.

92 Hamilton, 'Periodicals of Literary Interest', p. 449.

93 'Editorial Reflections', The Ladies' Mirror, July 1922, p. 10.
} 
lives, and suggests "while they may have evinced an interest in the Women's Movement, they were not ready for a periodical that ignored their experience and concerned itself solely with feminist issues". ${ }^{94}$ This may not be strictly true, but Hughes also points out even the feminism of Daybreak and White Ribbon was one which largely argued for women's rights "from within the ideology of 'separate spheres'”.95 Susan Upton's study of a different kind of women's space, the women's club, argues that club members were capable of balancing their domestic concerns with wider interests: "These women did not question that motherhood and the welfare of their families was their top priority but this did not prevent them welcoming outside activities". ${ }^{96}$ Women's lives were capable of great variety, as the contents of The Mirror show. Advocacy of one form of femininity was not a dismissal of others; The Mirror contained room for more than one way of being women.

In 1932 The Mirror's claim to be New Zealand's primary space for women was challenged by the arrival of the New Zealand Woman's Weekly. Woman's Weekly was, as its title suggests, a weekly rather than monthly publication, and it was substantially cheaper, costing three pence rather than a shilling. Its print quality was noticeably lower. It was not necessarily launched as a direct competitor to The Mirror; its creators, Otto Williams and Audrey Argall, had both been involved in The Mirror, Williams for a period as editor. There was even an advertisement for the Mirror's snapshot competition in Woman's Weekly's first issue. In this introductory issue, Woman's Weekly made similar claims to The Mirror: that no publication like it existed in New Zealand and that it was a necessity this gap be filled. ${ }^{97}$ They were different kinds of magazine. The Mirror was an aspiring quality journal that nevertheless occasionally made room for more humble readers. Woman's Weekly set out to be an everywoman's

\footnotetext{
${ }^{94}$ Hughes, p. 116.

95 Hughes, p. 110.

${ }^{96}$ Susan Upton, 'Women in the Club: Women's Clubs in the Wellington Region, 1895-1945', MA Thesis, Victoria University of Wellington, 1993, p. 8.

97 'Introducing the New Zealand Woman's Weekly', New Zealand Woman's Weekly, 8 December 1932, p. 6.
} 
journal from the beginning, aspiring to be "a cheerful companion for every New Zealand woman and child; a friend to be welcomed and looked forward to in every New Zealand home, no matter how humble or how exalted". ${ }^{98}$ While the success of the Woman's Weekly has been attributed as a contributor to The Mirror's eventual demise in 1963, that was many years down the line. In 1932, the arrival of the New Zealand Woman's Weekly proved that The Mirror was right to claim there was plenty of room for women's magazines in New Zealand. 


\section{The Girl of Today}

The Mirror presented itself as a magazine for the modern woman, but the modern woman of the 1920s was often a controversial figure, particularly the young modern woman. Across the globe she was noted for her difference in appearance and behaviour. The 'flapper' or 'modern girl' became a recognised and much discussed figure within the popular press. The popular image of the modern young woman was bold and independent, a radical departure from the drab and demure 'angel of the hearth' that characterised Victorian femininity. While her grandmother had been weighed down by her petticoats and never went anywhere without a chaperone, the modern girl cut her hair, wore short skirts and rushed about from tennis court to jazz club. She became an emblem of the modern world, a symbol of both its promises and its threats.

The Mirror allows a glimpse at how the modern girl was discussed and considered in New Zealand. In 1923, a piece by Mirror columnist 'Olivine', introduced the idea of 'The New Zealand Flapper'. “O, she's a gay little thing, the New Zealand Flapper, and as smart, both in appearance and in thought as they're made" explained Olivine. ${ }^{99}$ Found by day typing away at the office, she spent her evenings frolicking at the cabaret or the pictures and her weekends at the seaside. While usually attended by a young man "as full of fun and frolic as she", the flapper avoided being tied down:

Engaged? No, certainly not! Not yet is she going to tie herself up to husband and housework: no, not for many a long day. The young man is her escort, her Valier, her dancing partner, her playmate; there is no question of engagement and its attendant curtailment of freedom. Marry? Nonsense! Not while she can earn two pounds 
weekly in a comfortable office and spend every evening, her Saturday afternoons and her Sundays frolicking. 100

Olivine described a vision of young womanhood that was carefree and independent, and indulging in the pleasures of modern life. Olivine's explanation of the 'New Zealand Flapper' fits within a wider trend during this period of intense press interest in modern young women. Adrian Bingham argues that there was a "widespread conviction that there had been a profound dislocation with the past and transformation in the position of women". ${ }^{101}$ The image of the short-skirted and short-haired flapper was ubiquitous not only in the popular daily press, but also in literature, the cinema and advertising. He quotes an article in Newspaper World from 1927 which claimed "In the old days a two-page account of murder... was the great attraction, now it seems to be what some-well known man or woman thinks of the modern girl".102 Billie Melman also emphasises the intensity of the discussion surrounding the flapper, describing it as "a madness of sorts", which "surpassed earlier discussions on women and sexuality". 103

Melman uses this 'madness' to argue that the rise of the flapper in public debate represented a significant change in popular imaginings of women. Her work in 1988 was followed by several others who also stressed the wider social significance placed upon the 'flapper', 'modern girl' or 'garçonne', as she was variously known. French historian Mary Louise Roberts argued that in France the attitudes and behaviours of these young women were seen to represent dramatic social change; they took on the weight of postwar anxieties about the future of the nation and the race.104 Brigette Søland too paired the "sexual upheaval" of the First World War with the development of a new modern femininity in Denmark and across Europe, although she also noted the

100 Ibid.

101 Bingham, pp. 48, p. 81.

102 Newspaper World, 16 April 1927, p. 3, in Bingham, p. 48.

${ }^{103}$ Billie Melman, Women and the Popular Imagination in the Twenties: Flappers and Nymphs (New York: St. Martin's Press, 1988), pp. 1-2.

104 Mary Louise Roberts. 
importance of women's political gains. ${ }^{105}$ Susan Kingsley Kent focused on feminism rather than the modern girl, but she too took the war as a moment of substantial gender upheaval. ${ }^{106}$ These works, all published within ten years of one another, share a common thread - the First World War as a moment of change, real or perceived, in these nations' gender dynamics. This sense of rupture is conveyed across their titles - Civilisation without Sexes (Roberts), Becoming Modern: Young Woman and the Reconstruction of Womanhood in the 1920s (Søland), and Making Peace: The Reconstruction of Gender in Interwar Britain (Kent).

The First World War figures heavily in these historians' understanding of change for women and the societal response to it, but it is not an explanation that applies so readily to New Zealand. The scale of women's engagement in the war effort in Europe was massive, as they took on new roles in hospitals, canteens, farms, and factories. While these women were largely praised for their contributions, others did raise concerns about the freedom women gained during this period. A particular focus of this concern was the working-class munitions worker, who was paid relatively well and often used war work as an opportunity to escape a more restrictive life in domestic service. The criticisms levelled against the munitions girl and other war workers foreshadow those directed at the modern girl - primarily that they had too much freedom and were misusing it.107 New Zealand was an active participant in the war, but was removed by considerable distance from the fighting, and as a result New Zealand women's war experiences were different. Roberto Rabel argues that in New Zealand, women's wartime contributions were largely limited to the traditionally female tasks of "knitting, nurturing and nursing" and that as a result "prevailing assumptions about traditional gender roles were barely

\footnotetext{
105 Søland, p. 4.

106 Kent.

107 Claire Culleton, Working-Class Culture, Women, and Britain, 1914-1921 (New York: St. Martin's Press, 1999), pp. 51-73; Margaret Darrow, French Women and the First World War (Oxford: Berg, 2000), pp. 198-202; Angela Woollacott, On Her Their Lives Depend: Munitions Workers in the Great War (Berkeley: University of California Press, 1994), pp. 113-133.
} 
stirred let alone shaken".108 Erik Olssen has even argued that the war strengthened New Zealand's existing gender divisions by “render[ing] women's dependence normative and obligatory".109 These comments perhaps minimise the impact of the war on New Zealand women; after all, even sending knitting overseas required an incredibly high level of organisation from women volunteers, and while nursing might appear suitably feminine, in reality it often required hard work and tough conditions that were decidedly not. It is fair to say, however, that New Zealand women were not mobilised on anything like the same scale as their European counterparts, and few experienced the battlefront first hand. Yet despite lacking this supposedly crucial experience, Olivine's observations in The Mirror show that New Zealand's young women were clearly not untouched by modernity; they, like their European counterparts, were living notably different lives from their mothers and grandmothers.

More recent studies cast a slightly broader net, helping to draw in Olivine's 'New Zealand Flapper'. Most notably, The Modern Girl Around The World Research Group has emphasised the 'Modern Girl' as a worldwide phenomenon, one who appeared almost simultaneously across the globe. Young women with modern girl features - "bobbed hair, cloche hats, elongated bodies, and open easy smiles" - could be found in a range of media not just in Western Europe and America but also locations as diverse as China, South Africa, India, Soviet Russia and Australia. ${ }^{110}$ Others outside this group have also found modern girls in unexpected locations. Louise Ryan, for instance, locates the flapper in rural Ireland, challenging the idea that modernity was only to be found in the urban metropolis. ${ }^{111}$ The varied findings of these historians demonstrate that although similar images of flappers and modern girls appeared in magazines

\footnotetext{
108 Roberto Rabel, 'New Zealand's Wars', in Giselle Byrnes (ed.), The New Oxford History of New Zealand (Melbourne: Oxford University Press, 2009), p. 254.

109 Erik Olssen, Building the New World, p. 224.

110 Modern Girl Around the World Research Group, 'The Modern Girl as Heuristic Device', p. 13.

111 Louise Ryan, 'Locating the Flapper in Rural Irish Society: The Irish Provincial Press and the Modern Woman in the 1920s', in Ann Heilmann and Margaret Beetham (ed.) New Woman Hybridities: Femininity, Femininism, and International Consumer Culture, 1880-1930, (London: Routledge, 2004), p. 99.
} 
and newspapers across the globe, the discussion surrounding them was often very locally specific. While in France she encapsulated fears about the impact of the First World War on gender dynamics, in Ireland she was seen as a pernicious English influence and a threat to the new Irish state, and in America, South Africa and Australia she raised questions about beauty, respectability and race. ${ }^{112}$ The differences in how the modern girl appeared and was perceived across the globe allow historians to use her as a 'tour guide', "not only to the territory of gender and sexuality, as we might suppose, but also into unexpected places, into the history of nationalism, racial formations, global trade, and the transnational flow of people and ideas". 113 Appearing to many as an emblem of modernity itself, the modern girl had the power to reveal her contemporaries' hopes and fears about the modern world.

This chapter uses The Mirror to explore how these debates about young women and modernity played out in New Zealand. Olivine's column draws attention to the idea of a new vision of femininity that was not only a product of the modern world, but specific to New Zealand. Olivine's piece is just one of many discussions of flappers and modern girls in The Mirror. As elsewhere, young women were often viewed in The Mirror as a symbol of modernity; the rapid change of the world manifesting in the character of young unmarried women. However, The Mirror's modern girl was generally a positive figure. Characterised by pluck and good health rather than glamour and indolence, she was a celebrated sign of the boons of modernity, and was happily contrasted with her Victorian grandmother. "The fainting and anaemic girl of a generation

112 Roberts; Ryan, pp. 90-91; Davarian L. Baldwin, 'From the Washtub to the World: Madam C. J. Walker and the "Re-Creation" of Race Womanhood, 1900-1935', in The Modern Girl Around the World Research Group, The Modern Girl Around the World: Consumption, Modernity, and Globalisation, (Durham: Duke University Press, 2008), pp. 55-76; Lynn M. Thomas, 'The Modern Girl and Racial Respectability in 1930s South Africa', in The Modern Girl Around the World, pp. 96-119; Liz Connor,"'Blackfella Missus Too Much Proud": Techniques of Appearing, Femininity and Race in Australian Modernity', in The Modern Girl Around the World, pp. 220-239.

113 Kathy Peiss, 'Girls Lean Back Everywhere', in The Modern Girl Around the World Research Group, The Modern Girl Around the World: Consumption, Modernity, and Globalisation, (Durham: Duke University Press, 2008), p. 348. 
or two back has vanished", claimed one Mirror editorial. Instead, she had been replaced by the "athletic, high-spirited girl of to-day".114

One of the key attributes of the 'girl of today' was her athleticism. Charlotte Macdonald has drawn a clear link between modernity and the active body, claiming that "so central had the pursuit of the 'better body' become by the 1930s that it seemed almost to define the modern condition".115 The Mirror appeared to agree. "This is essentially the day of the sports-girl" it declared. ${ }^{116}$ Its pages were filled with images of young women engaging in a variety of sports, while feature articles celebrated local sportswomen's achievements and regular golf and tennis columns provided both sporting updates and tips for improving one's game. It suggested plans for walking holidays and camping trips. An article entitled 'In Praise of the Sports Girl', discussed the benefits of this new active lifestyle: "the new outdoor life of women and girls is one of the healthiest and most wholesome signs of our time, and it should inspire us with bright hopes for the days to come." 117 The idea that athletic women were also healthy ones was relatively recent, as Victorian understandings of the body assumed that sport sapped one of energy, making the overactive woman weaker and less fit for maternity. ${ }^{118}$ This attitude still lingered in the 1920 s, and can be found in the occasional Mirror article which warned young women against overtaxing themselves. One such article argued that women who played too much sport altered their physiology, over-strengthening the manly part of the brain and making them unfit for marriage.119 Generally, however, The Mirror supported the growing association between an active lifestyle and good health, and praised young women for engaging themselves in sports.

\footnotetext{
114 'Editorial Reflections', The Ladies' Mirror, January 1923, p. 4.

115 Macdonald, Strong, Beautiful and Modern, p. 12.

116 'In the Mirror', The Ladies' Mirror, October 1925, p. 4.

117 'In Praise of the Sports Girl', The Ladies' Mirror, March 1923, p. 7

118 Macdonald, Strong, Beautiful and Modern, p. 13.

119 Dr. Leonard Williams, 'Woman's Dual Life', The Mirror, December 1926, pp. 74-75.
} 


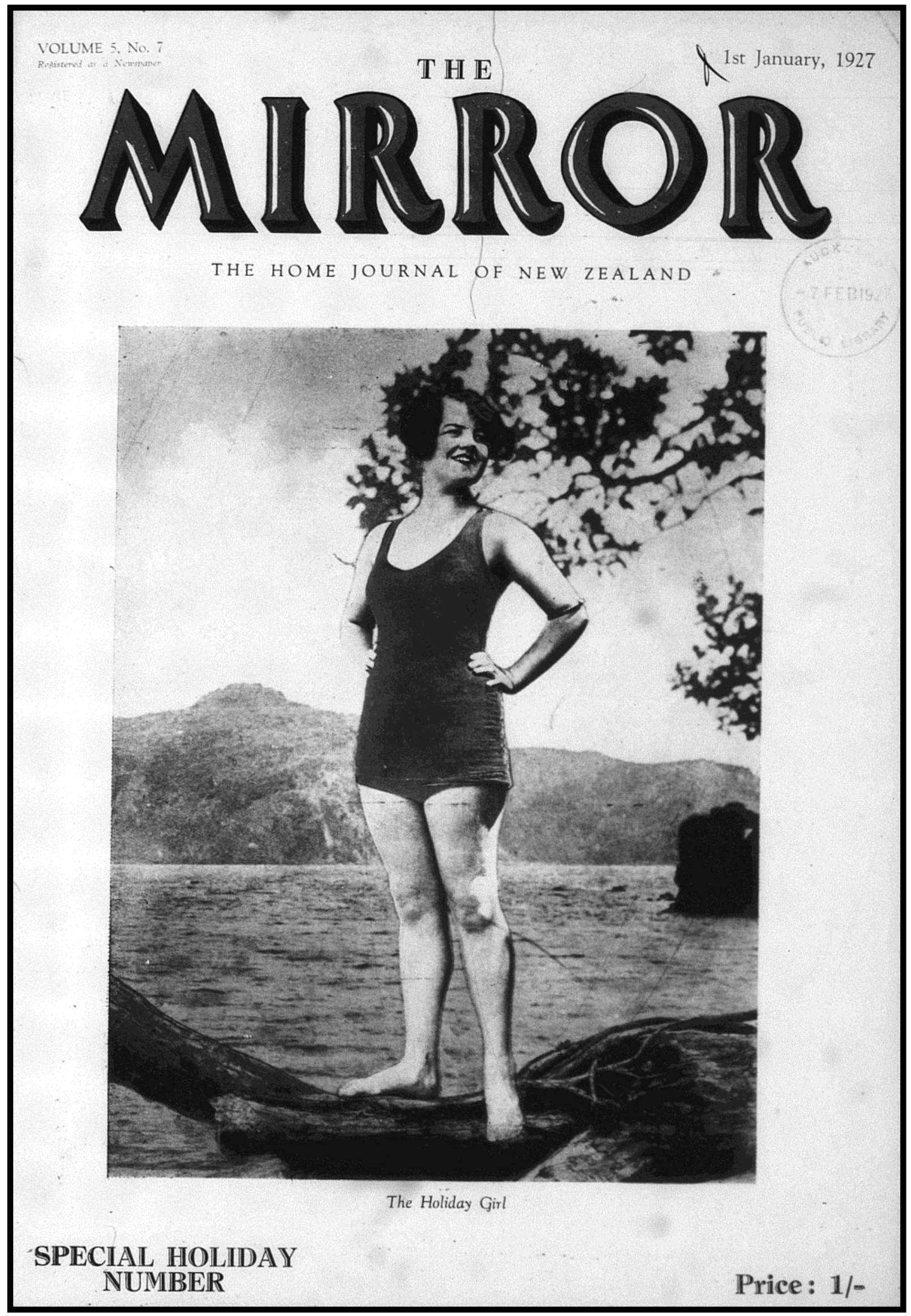

'The Holiday Girl', The Mirror cover, January 1927. 
The values of the girl of today were to be seen through her participation in youth organisations like the Girl Guides and the Young Women's Christian Association (YWCA). In an early issue of the Mirror a feature article explores the Auckland YWCA, describing the various activities its members were involved with. Not only did the YWCA have sports facilities - tennis, basketball, hockey, and many others - but also a variety of clubs and classes organised by members. Members taught each other knitting and cookery, and formed a literature group, a debating club, and even a thrift club, through which the YWCA acted as a small scale savings bank. All this taught members important values: "Self-reliance, self-government, loyalty, co-operation and service - these basic principles of service are all the time being taught in a practical way".120 Girl Guides feature often in The Mirror, and the magazine was full of praise for the movement's "excellent work in forming character and strengthening the physique of our young girlhood".121 Teaching its members to "Lend a hand and play the game", the guide movement combined healthy outdoor physical activity and useful skills with strong ideas about duty, character and good citizenship.122 Young women's engagement with these youth organizations allowed their growing independence to be viewed instead as 'self-reliance', and proved that modern young women could direct their freedom and energy in a positive direction: towards self-improvement and community service.

One of the most commented on aspects of the modern girl was her boyish style, but about this too, The Mirror was largely complimentary. The 1920s saw the rise of a new mode of fashion, in which short, boxy dresses obscured women's natural curves and hair was cut short in a bob or the even more dramatic 'eton crop'. The fashion eroded distinctions between men and women but it also made it harder to identify the class of the wearer; Elizabeth Wilson describes it

120 'The Girl as Nation Builder: What is Being Done For Our Girls - The Auckland Y.W.C.A.", The Ladies' Mirror, September 1922, p. 7.

121 'Our Girl Guide Movement', The Ladies' Mirror, December 1925, p. 67

122 Ibid; 'The World-Wide Movement of Girl Guides', The Ladies' Mirror, July 1923, p. 12. 
as a "classless style", "the apotheosis of the shopgirl's uniform".123 This new style was often inscribed with wider meaning. Melman writes that "contemporaries regarded this figure as the symbol of the new morality, a sign of the transition from a sexually and socially heterogeneous society to one that was unisex, uniform and classless". ${ }^{124}$ Roberts reports that in France women's fashion bore the brunt of postwar cultural anxiety. The new styles were widely read as an explicit rejection of femininity, a sign of Frenchwomen's "inability to be defined within the boundaries of traditional womanhood". ${ }^{125}$ In Ireland these fashions were suspect because they seemed to represent an encroaching Englishness on Irish womanhood and Catholic virtue. ${ }^{126}$ Often the modern girl's dress was seen as a harbinger of doom, a sign of growing immodesty and social decay.

The Mirror however, offered an alternate view: the new fashion was practical and sensible. It was, after all, the girl of today's simple style of dress that allowed her to live the healthy and active lifestyle she did:

Nor have they hesitated to sacrifice the fashion of their clothes to their growing health. Real fitness simply could not live in the dresses our mothers and grandmothers wore. A low-cut blouse may be hateful to people who never felt the joy of unrestricted breathing; but to the modern athletic girl it is simply an obvious advantage. The same thing applies to the short skirt. ${ }^{127}$

While the Victorian woman was hampered by her heavy skirts, the girl of today moved free and easy. One writer pointed out with jealousy the ease of dress these new styles afforded the girl of today: “isn't it enough to make an old stager from the days of leg-of-mutton sleeves and buttons up the back perfectly green with envy to see the sweet simplicity of the dresses affected by that complex

\footnotetext{
123 Wilson, p. 41.

124 Melman, p. 5.

125 Marie Louise Roberts, pp. 20, 63-87.

126 Ryan, pp. 98-99.

127 'Are Women Growing Fitter?', The Ladies' Mirror, April 1925, p. 64.
} 
young person, the modern girl?"128 Others suggested that men would benefit from a similar revolution in their own dress, as the modern woman was far more comfortable in her loose, lightweight dress than the men who sweltered in woollen suits. ${ }^{129}$

The Mirror's mothercraft column gave advice to those who had a little more difficulty with the girl of today. Parenting the modern young woman, it argued, required a modern approach, as mothers could not expect their daughters to behave as they might have done. "I move with the times! What is the good of behaving like a Victorian mother to Miss 1924?" declared the author. ${ }^{130}$ Modern parenting as portrayed in The Mirror generally required a closer, more candid relationship with children. Mothers were encouraged to be more understanding of their daughters, and to encourage a more trusting, equitable relationship. One such article discussed the desire of working young women to live outside the family home. While parents tended to see leaving home as "one more example of the self-will and ungratefulness of the modern generation", the Mirror explained that in reality it was "merely the outcome of a natural desire to live her own life and to develop her own individuality". 131 However, if parents did want their daughters to stay at home, they had to make an effort to make it a more welcoming environment. Working daughters should be given space, and not accused of being unsociable if they needed to spend some time alone in their rooms. Importantly too, they should be treated the same as their working brothers, and not be expected to take on domestic responsibilities if their brothers were not. ${ }^{132}$ Another explained how mothers should actively encourage their daughters to bring their male friends to tea. In this way, she could get to know the boys her daughter was associating with, and help her make good decisions. The strict mother, who disapproved of male friends,

\footnotetext{
128 'Breezes From The Capital', The Mirror, February 1926, p. 26

129 'Cowards All: A Short Story by Sybil of the Short Skirt', The Mirror, December 1927, pp. 60-

61; 'In the Mirror', The Mirror, January 1928, p. 7.

130 'Mothercraft: Mothers and Daughters', The Ladies' Mirror, March 1924, p. 45.

131 'Mothercraft', The Ladies' Mirror, September 1923, p. 32.

132 Ibid
} 
would simply be lied to. 133 "It is right that parents should keep a watchful eye upon their daughters and try to guard and protect them", wrote another Mirror columnist, but "they must recognise the fact that they can no more use the same methods in 1928 that their parents used in dealing with their daughters a quarter of a century ago than they could use the same methods in business".134 In its mothercraft column, The Mirror acted as mediator between the girl of today and the older generations who could not understand her. The girl of today was not bad, The Mirror argued, she just needed to be understood, and The Mirror could help.

At times Mirror writers sought to reassure by stressing continuity as well as change. They argued that despite superficial differences, the girl of today and her Victorian grandmother were still ultimately "sisters under their skin". ${ }^{135}$ The author of the Wellington social notes, 'Dorothea', commented on this while discussing the success of a recent bake sale by the Wellington Pioneer Club:

Their exhibits were really very creditable. After all, in spite of her clubs and her sports, her slang and her cigarettes, the girl and the woman of to-day are every bit as housewifely as those of the Victorian age, and possibly, if the truth were sought for, more helpful in that they have a wider vision as to their responsibilities, and the need of helping those not so fortunately placed as themselves. Instead of remaining enclosed within the four walls of home, woman to-day goes out to work, not only for herself, but for humanity at large. 136

133 'Mothercraft: Mothers and Daughters', The Ladies' Mirror, March 1924, p. 45.

134 'Why Girls Leave Home: Dorothy Dix Pleads with Parents to Use 1928 Methods', The Mirror, May 1928, p. 36.

135 'The Mirror of Fashion', The Ladies' Mirror, January 1923, p. 17.

136 Dorothea, 'In The Mirror: Social Doings in the Various Centres', The Ladies' Mirror, July 1922, p. 7. 
In the girl of today The Mirror saw not a rejection of Victorian femininity, but an expansion; her new found independence allows her to use her gifts for a wider purpose.

Dorothea's claim that the girl of today is "every bit as housewifely" as those that came before is not out of place. Many argued the changes to the modern young woman were largely superficial, and would not deter her from her domestic role. Olivine's New Zealand Flapper might seek fun and frolic now, but later she would make a fine wife and mother:

'But,' says an embittered moralist, with down-drawn lips and wrinkled nose, 'what sort of a mother is she going to make?' Did she hear the query, she would reply with a toss of her dainty head, 'Don't worry, old Top, wait until the time comes and then see.' And, as a matter of fact, when she does decide to 'marry and settle down,' she makes a first-class housekeeper, wife and mother. As she herself would say, 'Well, I had my fling; I enjoyed to the limit every one of my Flapper days, but Life can't all be frolic, and now I'm content to make a home and 'run' it as well as a home can be run.' And so she does, and you may go into many a home and find it well managed, the little ones carefully trained, both physically and mentally, by the young woman, who not so long ago was a gay little Flapper.137

Indeed, many in The Mirror argued that the girl of today would make a far better wife and mother. Those who led athletic lives were, after all, "developing their bodies and strengthening their characters to reach the great goal: healthy motherhood, which is to carry our young nation to the fore in all things". ${ }^{138}$ Greater maternal health meant better babies, and, as 'A Lady Doctor' attested in 1925, “anyone who sees many of the modern girls' babies can only be struck by

137 'Observations of Olivine', p. 12.

138 'In the Mirror', The Ladies' Mirror, October 1925, p. 4. 
their health and development".139 The efficiency of her housewifely skills was also improved by her fitness and health, as "the menfolk of fit women are better fed and better looked after than those who depend on sickly and overtired wives and mothers". ${ }^{140}$ Frequent comments such as these reassured the reader that today's young women were not abandoning the domestic sphere. Instead, they were equipping themselves to becoming better wives and mothers, and, in doing so, improving the strength of the nation.

The girl of today was more likely, however, to take her time to get there. Job opportunities for women in the early twentieth century were expanding rapidly, and it was increasingly expected that young women would work between school and marriage, even amongst the well-to-do. ${ }^{141}$ This expectation was evident in The Mirror. Many of The Mirror's articles were directed specifically at the working 'bachelor girl', particularly those who no longer lived in their family homes. 'Beauty Tips for Tired Workers', for example, advised women on 'freshening up' after a hard day's work. ${ }^{142}$ 'Schemes and Ideas for Milady's Room', helped the reader on a budget transform a pokey bedsit into an elegant apartment. ${ }^{143}$ The 'In the Kitchen' column ran several articles on cooking and hosting in a bedsit, with recipes designed for a gas ring and advice on growing herbs in window boxes. ${ }^{144}$ Generally, the magazine viewed work as a valuable life experience for young women, and mothers were encouraged by The Mirror's mothercraft column to support their daughter's desire to work outside the home.145 The happily independent working woman was a sign of positive change for women, of their expanding sphere. She was thought to contribute to society in her own way, bringing a broader perspective and a feminine touch to her work, whatever it might be. And women as a result had

\footnotetext{
${ }^{139}$ A Lady Doctor, 'Sport \& Motherhood', The Ladies' Mirror, November 1925, p. 61.

140 'Are Women Growing Fitter?', The Ladies' Mirror, April 1925, p. 64.

141 Olssen, 'Working Gender, Gendering Work', p. 59, 75-78.

142 'Beauty Hints for Tired Workers', The Ladies' Mirror, October 1925, p. 64.

143 'Schemes and Ideas for Milady's Room', The Ladies' Mirror, June 1924, p. 21.

144 'In the Kitchen: Gas Ring Cookery', The Mirror, October 1927, p. 79; 'In The Kitchen: Just that Touch!', The Mirror, March 1929, p. 75.

145 'Mothercraft: Mothers and Daughters', The Ladies' Mirror, March 1924, p. 45.
} 
greater choice and opportunity, even if they did decide to marry. As one article pointed out, "the parent of 1923 with a family of daughters may confidently look forward to girls finding their own way to financial independence, without choosing the only Victorian avenue, matrimony."146 The girl of today's ability to support herself meant that when she did get married, it was not out of financial need, or some desperate desire to leave her parents' home. It allowed her to approach marriage and family life with careful consideration, treating it as the serious responsibility it was.

While for most women working life was assumed to be temporary, there were times when The Mirror supported the possibility that the girl of today might have a future that did not revolve around becoming a wife and mother. An article on 'Miss 1925 Twenty Years Hence', was interested not in what would happen to 'Miss 1925 ' when she became a wife, but when she did not, as "there will be a very large proportion of women who have carefully weighed the question of marriage and decided to remain single - efficient, cheerful, useful women who have moved with the times". ${ }^{147}$ The girl of today's independence, both financial and otherwise, meant that her future no longer depended on marriage. As one Mirror writer explained, "She is not restricted to marriage as practically the only career open to her. In the arts and in the professions she is finding a career, and not only wider interests in life, but economic independence. The urgent need for marriage does not dominate her thoughts."148 The Mirror encouraged these careers, with features on women doctors or lawyers that both celebrated their contributions and provided the reader with practical advice on how to enter these professions themselves. ${ }^{149}$ Articles like this gave a sense that women could, and should, contribute to the

\footnotetext{
146 Chas. E. Wheeler, 'Women in New Zealand Industry: Their Activities Surveyed - A Wide Range and Improving Pay', The Ladies' Mirror, December 1923, p. 14.

147 'A New Style of Old Maid: A Vision of Miss 1925 Twenty Years Hence', The Ladies' Mirror, September 1925, p. 26.

${ }^{148}$ Lady Forbes-Robertson, 'Is Platonic Love Possible?', The Mirror, August 1926, p. 26 ?

149 'Women in the Medical Profession: Lady Doctors in the Dominion', The Ladies' Mirror, November 1922, p. 3; 'Women as Chemists', The Ladies' Mirror, June 1923, p. 18.
} 
world outside the domestic sphere: business, politics, education - all could benefit from feminine input. Importantly, The Mirror suggested they could find such a role just as fulfilling as motherhood: "She has her job or her profession, her $£ 250$ or $£ 300$ a year. She has her neat little flat, with its bookcase, blue china and piano. She has her friends, week-end trips are always awaiting her, her clothes interest her, her holiday plans. She is satisfied".150 More than one of these articles suggested that the concept of the 'old maid' was now dead, not because women were more likely to get married, but because an unmarried life no longer set one apart: "The old maid with the mittens and the small army of cats is a 'back number' to-day". ${ }^{151}$ The girl of today made a good wife and mother, if she chose to, but she could be happy outside marriage too.

While generally The Mirror presents a much more positive view of modern young women, alternate visions of the modern girl were also present in the pages of The Mirror. In 1928 it published a short story by John Thornton, 'Dream Girl'. David, the story's hero, has just started work at a new company and has drawn the interest of the 'office flappers'. However, David is hardworking and disinterested in their advances. His pockets, unlike the other men of the office, are empty of gin, and the flappers' "broad hints as to availability of a night fell on deaf, though crimson, ears".152 One of his encounters with the flappers is described in detail:

Perched on a desk in front of him, chattering volubly, with several inches of satiny skin showing above one of her garter rolls, was one of the most dangerous of the flappers. A clumsy little worker whose name had, the winter before, been tossed back and forth in newspaper accounts of a divorce suit. ${ }^{153}$

\footnotetext{
150 Kathleen Norris, 'The Girl Who Doesn't Marry', The Mirror, August 1927, p. 47.

151 'A New Style of Old Maid', p. 26.

152 John Thornton, 'Dream Girl', The Mirror, October 1928, p. 28.

153 Ibid, p. 28.
} 


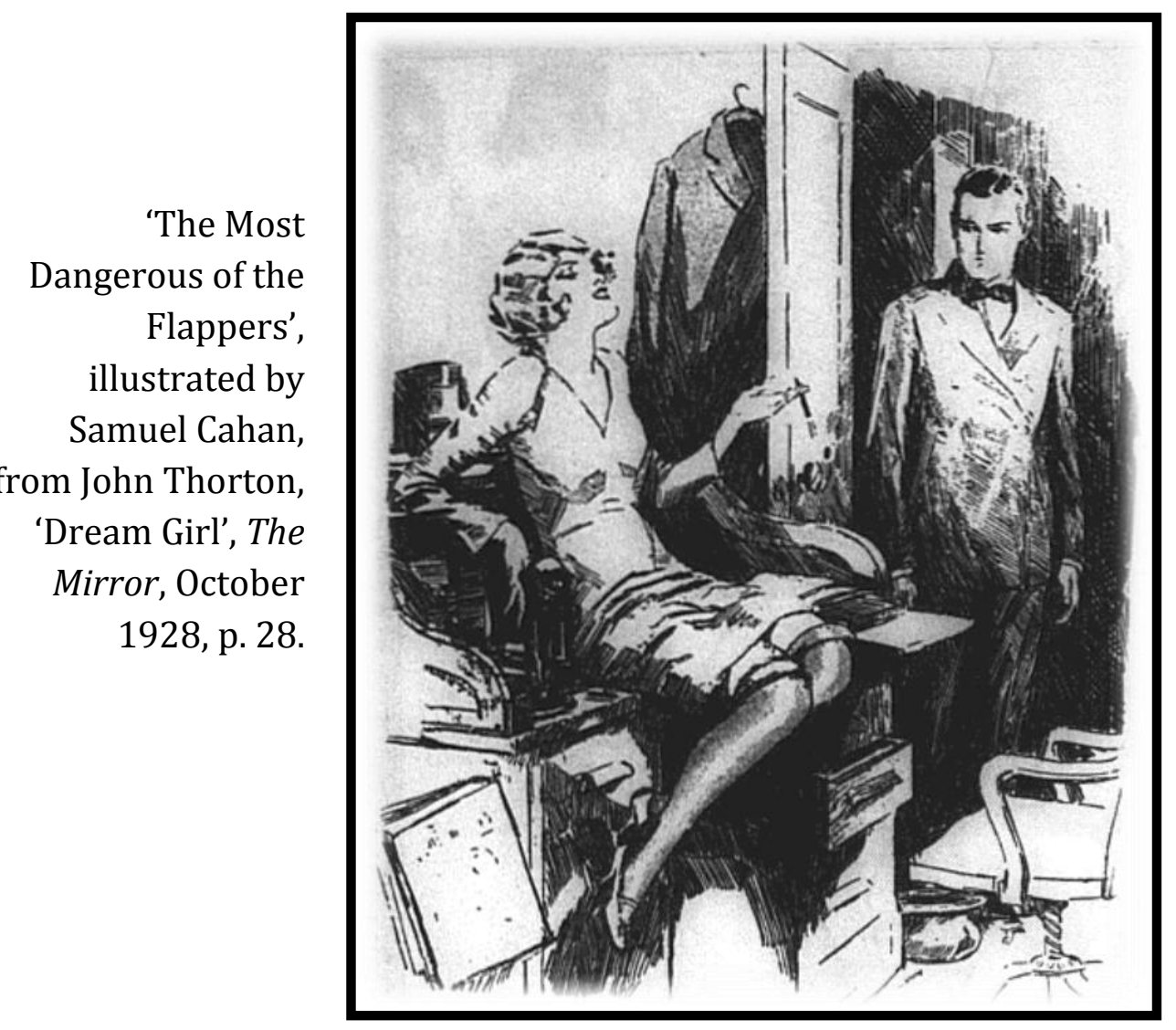

This image is strikingly salacious. Here the flapper is presented as a predatory figure, one who represents the dangers of modern life - sex, liquor, and divorce. She is not even good at her job; she goes to the office to flirt rather than work. Her attempt to lure the hero into her hedonistic lifestyle is unsuccessful as David has no interest in "the follies of his sex-conscious, jazz-crazy, hip-pocket generation" and ultimately ends up with his dream girl, "a demure, wholesome little creature". ${ }^{154}$ While the story's conclusion appears to warn against the evils of modern life, it is an illustration of the 'dangerous flapper' who sat on David's desk which accompanies it, with the tops of her stockings rolled down and cigarette in hand. The flapper might not be an ideal role model for young women, but she was still a powerfully compelling figure. Stories like this one indicate that while The Mirror did not believe most women wanted to be her, they still wanted to read about her. 
The Mirror's support of modern young women was not limitless. Thornton's story provides one example of young women who found disapproval in The Mirror; the flapper who dedicates herself to drinking and flirting rather than her work. Another is found in a 1926 article on the 'Ultra-Modern Girl', which described her failings in depth. The author, J. Jefferson Farjeon, observed that young women had lately greatly increased their indulgence in drinking and smoking, make-up, slang, "pastimes demanding physical vigour", work - "apart from the household variety", late hours, and "individual independence and freedom of action". 155 He disapproved:

Now all these things may be right, and I may be wrong in thinking them wrong; yet I do believe they are working against rather than for the general welfare, and that they are tending to induce neuroticism, ill health (with its glorification of temporary substitutes), and a general lowering of our spiritual standards. ${ }^{156}$

Farjeon's disapproval of the 'ultra-modern girl' is a timely reminder of the often contradictory nature of magazine content. Most of the activities on Farjeon's list are celebrated or at least defended elsewhere in The Mirror. Drinking, for example, was the subject of a 1924 editorial. While The Mirror did not support excessive drinking by young women, it argued that their propensity to do so had been grossly exaggerated:

That a few girls think it is 'smart' to be seen drinking too frequent cocktails I know is true, and more's the pity, but that the vast majority are addicted to the cocktail and 'spot' habit I do not for a moment believe ... Wholesale condemnation of this nature is unjust. It leads many to believe that the evil is far more widespread than it

155 J. Jefferson Farjeon, 'The Ultra-Modern Girl', The Mirror, April 1926, pp. 44-45.

156 Ibid 
actually is, and casts a reflection on the whole of our womanhood. 157

Part of The Mirror's support of the girl of today came from the belief she was not actually guilty of most of the things she was commonly accused of. In this sense, Farjeon's distaste for the 'ultra-modern girl' does not seem quite so contradictory. After all, she is not just the modern girl, but the ultra-modern girl. Disapproval of modern young women found in The Mirror was often focused on those who went to extremes, who abused the freedoms of modernity, but it generally emphasised they were not the norm. Even Farjeon acknowledged that "between the prehistoric Victorian girl and the ultra-modern girl there is a girl of sound sense and limb who exists, happily, in comfortably large numbers". ${ }^{158}$ The ultra-modern girl was an aberration, but also an exaggeration; the truth was that most modern young women were sensible and ordinary.

If, as other historians have suggested, public debate surrounding the modern girl reveals something of the local contexts, then what does The Mirror's girl of today reveal about New Zealand? It seems to indicate a much more optimistic view of the modern life in the early twentieth century than might be found elsewhere. There are, of course, other arguments aside from New Zealand exceptionalism. Bingham, for one, argues that in Britain the depiction of the modern girl in the popular press was substantially more positive than other historians have acknowledged. ${ }^{159}$ Importantly, too, The Mirror had its own reasons for projecting a more positive attitude about modern young women. The Mirror was, after all, a women's magazine. While The Mirror's demographic was possibly slightly older - the girl of today's mother, rather than her herself a magazine that too frequently scolded women for their personal choices was unlikely to entice them into reading. Also, The Mirror's celebration of young

\footnotetext{
157 'In the Mirror', The Ladies' Mirror, October 1924, p. 4.

158 Farjeon, p. 45.

159 Bingham, p. 49.
} 
women allowed it to articulate a modern identity. By disputing much of the criticism against young women The Mirror set itself apart as a magazine which understood and supported the needs and desires of modern women. Praise for the girl of today enabled The Mirror to align itself with modern femininity, and present itself as a modern, up-to-date magazine.

It does seem, however, that much of the anxiety about the modern woman that existed elsewhere was absent in New Zealand. This is perhaps understandable. In Europe, where these anxieties were most pronounced, once strong empires were now fading, class and gender barriers appeared to be eroding and the future was uncertain. In New Zealand, these worries seemed far away. Tammy Proctor suggests that the "only vital and expanding part of the empire after the war seemed to be the white Dominions". 160 In New Zealand it was still possible to believe strongly in the power of the British Empire. It was also a place where egalitarianism was assumed to be both widespread and a virtue, a belief which, true or not, left less room for class panic. The result was that a slightly different picture of young womanhood took form within The Mirror than what has often been associated with modern girls. The girl of today was healthy and happy. She was capable of motherhood but not limited to it. She was motivated by values of service, duty and self-reliance, and took advantage of her increased independence and opportunity not for selfish gain but to expand her horizons and improve society. She was the promise of modernity, not its threat; a hopeful image of the future.

160 Tammy Proctor, On My Honour: Guides and Scouts in Interwar Britain (Philadelphia: American Philosophical Society, 2002), p. 134 


\section{3.}

\section{Modernity in the Home: An End to Drudgery}

The changes that modernity brought with it were not limited to the 'girl of today'. Wives and mothers too experienced change, and these changes are reflected in The Mirror's more domestic content. Articles that focus on home life are one of the staples of the women's magazine, and The Mirror was no exception. It instructed readers on how to throw dinner parties and provided suggestions for decorating their homes. It provided them with recipes and patterns for feeding and clothing their families, and advice on keeping children happy and healthy. It connected them to a variety of experts, from Melanie Primmer, editress of 'The Up-To-Date Housewife', to Plunket nurses and child psychologists. The Mirror's domestic advice helped women run a modern home as they attempted to navigate a changing world. The family was smaller and the layout of the house was changing. Servants were scarcer, but science and technology found their way in, with new 'labour-saving' devices and scientific methods for improving household efficiency. The modern housewife that emerged as a result of these changes has often been seen as a trap for women, a role that was oppressive and restrictive. But in The Mirror modernity promised to lighten women's load, creating homes that were happy, healthy, and clean, and freeing the modern woman from the role of household drudge.

The extent to which the modern world brought change to the home and the women that maintained it has been commented on elsewhere. Judy Giles stressed the way in which wider technological and industrial developments of the late nineteenth and early twentieth century had the power to bring about substantial change in women's daily lives. She points as an example to the growing availability of piped hot water, which not only vastly improved family health and hygiene but also eliminated the need for women to heat and carry water to where it was needed (an exhausting task), and created the new private 
realm of the bathroom. ${ }^{161}$ In Marilyn Irvin Holt's study of the 'modern farm woman' in rural America, she draws attention to another development - the spread of linoleum, arguing that linoleum floors were viewed by these women as key to the maintenance of a modern home. ${ }^{162}$ Alongside these developments in technology were changes in attitude. Giles' point about the new privacy of bathrooms hints at the ways in which there were shifts in understandings around public and private space, and increasingly, the home was perceived as a private and intimate family space. There was also an increasing emphasis on the importance of scientific knowledge and a rational, methodical approach to maintaining the home. Kerreen Reiger has described this as 'the disenchantment of the home', in which household work increasingly came under the influence of new professional experts including medical professionals, domestic science experts and child care specialists. ${ }^{163}$

Women's magazines were one way in which these new approaches and professional expertise could be transmitted, but their capacity to do so has often been viewed critically, interpreted as advocacy for limiting and restrictive roles for women. That they encouraged women to seek an idyllic and unrealistic vision of home life is one of the most constant criticisms made of the function of women's magazines. ${ }^{164}$ Studies of women's magazines have begun to push back at the assumption that they present a restrictive picture of womanhood, but the belief that they are inherently prescriptive persists. Stephen Hamilton used the domestic content of The Mirror to characterise the magazine as conservative and overly invested in women's "traditional role of mothers and wives". 165 I have already attempted to demonstrate that The Mirror did not generally consider women's domestic role to be their only interest or capability, but it

\footnotetext{
161 Judy Giles, The Parlour and the Suburb: Domestic Identities, Class, Femininity and Modernity (Oxford: Berg, 2004), pp. 20-21.

162 Marilyn Irvin Holt, Linoleum, Better Babies and The Modern Farm Woman, 1890-1930 (Albuquerque: University of New Mexico Press, 1995), pp. 88-89.

163 Kerreen M. Reiger, The Disenchantment of the Home: Modernising the Australian Family 18801940 (Melbourne: Oxford University Press, 1985), p. 2.

164 Winship, pp. 7-8.

165 Hamilton, 'Periodicals of Literary Interest', p. 449.
} 
certainly did provide women with advice and support in this area. Whether it was conservative or traditional is more questionable. This chapter more closely examines the vision of modern domestic life presented in The Mirror.

One of the biggest changes in the middle-class home of the early twentieth century was the decreasing presence of servants. This change is reflected in The Mirror. A 1924 article on 'The Bride's First Dinner Party' assumed the reader would have hired help; it was the capabilities of her cook rather than her own which she was advised to consider when planning her menu. ${ }^{166}$ In 1928 a similar article, 'How to Give A Bridge Luncheon', gave the same kinds of tips about table settings and etiquette, but makes no mention of domestic help. A few suggestions are made about the menu, but when it comes to the dessert the reader is advised to buy it ready-made rather than attempt a complicated dish herself. ${ }^{167}$ Her advice assumes a lack of domestic help in the home, but it also assumes access to a new world of consumer goods. That is not to say that servants were common in New Zealand homes in 1924 and in 1928 they were not. The different assumptions made by these two articles about the reader's access to domestic service could reflect a variety of things. Over the course of Mirror's first decade in print it gradually generalised its readership, and the difference between these two pieces could indicate a shift in the class of the intended reader as much as any modernising forces. It could also simply be a result of differences between the two authors. Generally, some articles assume the reader has servants, some assume she does not, and the latter became more common as time went on.

Discussion of domestic service in The Mirror is complicated by the many overseas articles it published, which could make assumptions about the availability of home help that did not reflect the New Zealand situation. New Zealand has always been a nation of few servants. This was in part due to a lack of those willing to do the job; single, working class young women were not

166 'The Bride's First Dinner Party', The Ladies' Mirror, May 1924, pp. 46-47.

167 Louise Dunn Ambrose, 'How to Give a Bridge Luncheon', The Mirror, July 1928, p. 78. 
particularly prevalent amongst New Zealand's early migrants, and attempts to get Māori to fill the gap were largely unsuccessful. The difficulty of obtaining reliable servants, the 'servant problem', as it was known, was a constant reality of nineteenth-century New Zealand and adapting to life without consistent domestic service was part of colonial life, even for the relatively wealthy. ${ }^{168}$ The situation did not improve in the early twentieth century; indeed, the number of women in domestic service shrank as alternate occupations became available to working-class girls. ${ }^{169}$ In contrast, Britain, where most of The Mirror's external content appears to have been sourced, had an abundance of servants, and the presence of at least some domestic help was a defining characteristic for middle class families. While increasing opportunities for working class women and decreasing wealth of the upper classes were beginning to have their effect by the 1920s, British writers still tended to assume an availability of domestic help that was not the reality in New Zealand. Because The Mirror did not always make it clear what content was original and what was sourced from overseas magazines, the casual mention of domestic service in housekeeping tips could be misleading.

However, the magazine's editorial content provides some interesting insights that are rooted firmly in the New Zealand context. The Mirror expressed concern at the servant shortage, and reported with approval on the New Zealand government's renewed attempts to entice British domestic workers to New Zealand through assisted immigration. The author of an article discussing the scheme, Chas. E. Wheeler, a regular Mirror correspondent, presented the shortage of domestic help in the dominion as a serious social problem. Wheeler wrote: "If we possessed a large class of complete idlers who made up the loud

\footnotetext{
${ }^{168}$ Charlotte Macdonald, 'Strangers At The Hearth: The Eclipse of Domestic Service in New Zealand Homes c. 1830-1940s', in Barbara Brookes (ed.) At Home in New Zealand: History, Houses, People (Wellington, Bridget Williams Books, 2000), pp. 42, 44; Judith Elphick, 'What's Wrong With Emma? The Feminist Debate in Colonial Auckland', New Zealand Journal of History, Vol. 9, No. 2, 1975, pp. 128-129.

169 Macdonald, 'Strangers at the Hearth', pp. 42, 44; Olssen, 'Working Gender, Gendering Work', pp. 73-75.
} 
chorus of complaint about the lack of help in the home, I personally would have not the slightest interest in the subject". 170 As it was, however, the shortage was a burden on overworked wives and mothers. A 1923 Mirror editorial was far tougher on domestic employers, arguing that the lack of domestic help was a direct result of women being unwilling to compromise on their servants' terms of service, making it an unappealing prospect for young women. Servants should be given plenty of freedom and time off, and their employers should be prepared to contribute to the domestic work as well:

Women must move with the times if they are to find a perspective in the new day and outlook of the younger generation, or it will be found that the last girl has gone to the industrial arena. We will have to makes some changes in our ideas and domestic schemes. If women think it above them, or too much of a bore, to assist in the work of the house, then it is likely that they will find themselves short of much-needed aid. If servants cannot be kept to work in relays, then those who are employed should have their definite hours of work, outside of which the mistress should undertake the duties of the home. Selfish women who refuse to recognise any such responsibility have done much to spoil the chances of the sensible woman with the rational point of view. The young, overburdened mother is paying for the less heavily laden woman who wants to play at being mistress of a home without soiling her hands. She seeks to shirk her duty, but servant girls, by their gradual evanishment, are deciding that whether she wants to or not she must do her duty. ${ }^{171}$

While Wheeler and the author of this editorial are in disagreement about the amount of work wealthy New Zealand women were doing around the house, their comments both demonstrate a view of domestic service as something that

${ }^{170}$ Chas. E. Wheeler, 'Domestic Help: The Shortage in New Zealand - How Immigration Fills the Gap', The Ladies' Mirror, March 1924, p. 25

171 'Editorial Reflections', The Ladies' Mirror, January 1923, p. 4. 
should be available to those who both need and deserve it - the 'young, overburdened mother', rather than the idle lady of leisure. It is an intriguing position to take from a magazine ostensibly aimed at the middle classes. In Wheeler's case it seems to stem at least in part from a belief in New Zealand's lack of class distinctions; the lady of leisure does not exist here. Additionally, as Charlotte Macdonald has argued, the self-sufficiency of the servantless household was seen as a virtue by many. ${ }^{172}$ The editorial certainly seems to be in favour of women getting involved in their own housework, if not becoming entirely responsible for it. The suggestion that women must 'move with the times' suggests another explanation. Its acceptance of the servant shortage as a reality that required a change of approach not only made The Mirror appear aware of modern realities, it also gave it the opportunity to direct a suitable solution. The Mirror was a magazine that not only encouraged women to 'move with the times', it appointed itself as their guide.

Compromise with servants was one approach; another was to do without them entirely, and increasingly, The Mirror presented a modern world in which women did not need servants. According to The Mirror, "the modern way is, of course, the electric way".173 New appliances replaced servants in doing the work of cleaning and maintaining the home. In 1926 The Mirror published what was essentially a three page advertisement for a local appliance company, the National Electric and Engineering Company, disguised as a short story, called 'The Abolition of Home Slavery'. Grace Forbes' maid Annie (the fifth that year) leaves after smashing an entire tray of crockery and Grace is at a loss for what to do. Her concerned husband sends her for a holiday with their friends, the Maitlands, in Hamilton. Grace is suspicious, vaguely aware that the Maitlands' household is run on "weird, scientific, new fashioned lines". 174 She is quickly converted, however, when Peggy Maitland shows her the ease of her vacuum cleaner, washer and electric iron; the rapidity of her electric cooker, kettle and

\footnotetext{
172 Macdonald, 'Strangers at the Hearth', p. 44.

173 'Modern Ways of Housekeeping', The Mirror, August 1926, p. 69.

174 'The Abolition of Home Slavery', The Mirror, February 1926, p. 30
} 
toaster; and the comfort of electric heaters and plumbed hot water. Peggy even has an electric curling iron, allowing her to wave her own hair just as well as a hairdresser. "Electricity is my servant, just as it's going to be yours - an alwaysready, always-dependable, always-efficient servant", explains Peggy. ${ }^{175}$

As Peggy demonstrates to Grace, electricity and the appliances it powered transformed the work of maintaining the home. The Mirror's housekeeping advice regularly stressed the time and effort which could be saved by embracing electricity and electrical appliances. Those like Grace, who relied on unreliable servants, or worse, attempted to do all the work themselves, were living in the past. Their approach was presented as old-fashioned and an unnecessary waste of energy - 'trouble chasers' according to Peggy. Similar themes can be seen in a later advertisement for an Electrolux vacuum cleaner, published in The Mirror in 1931. It suggested that sweeping rather than vacuuming was 'health-destroying drudgery' and compares it with wearing fashions almost thirty years old. ${ }^{176}$ These new appliances were more efficient than doing the work by hand, resulting in a more comfortable, cleaner home. But more than that, they lessened the burden of housework on women. As Peggy's husband Tom says:

It isn't only that we get perfect results... A big feature to my mind is the difference this, and all our other electric gadgets, make for Peggy, the ease and comfort they mean to her. Why, when I go out to office and know it's her washing day, I go easy in mind, knowing that there's none of the old-time drudgery for her to face, for our electric washing machine does all the work by the turning of a switch. ${ }^{177}$

\footnotetext{
175 Ibid, p. 31.

176 Advertisement for Electrolux Vacuum Cleaner, The Mirror, December 1931, p. 58.

177 'The Abolition of Home Slavery', p. 31.
} 


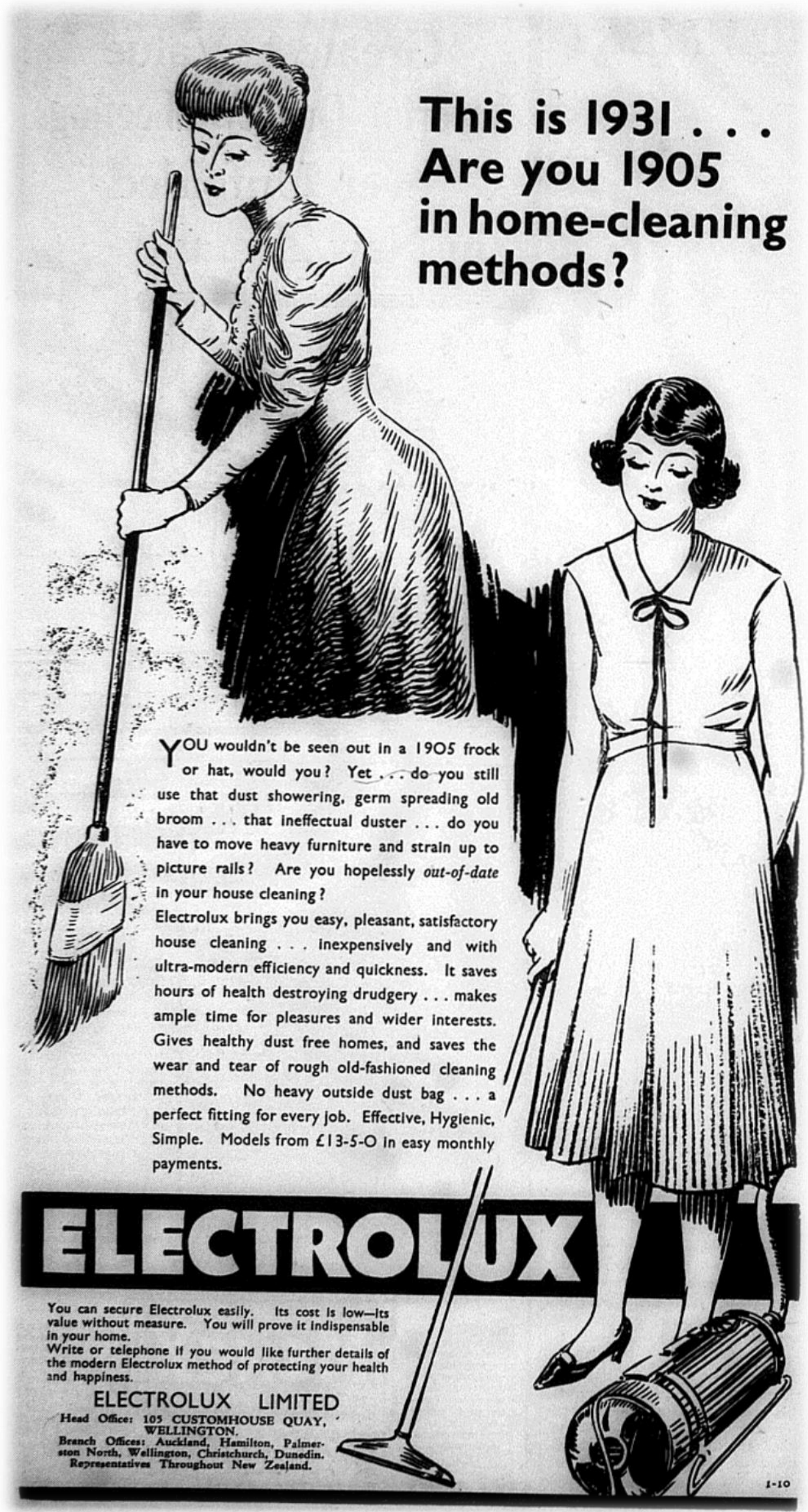

Electrolux vacuum cleaner advertisement, The Mirror, December 1931, p. 58 
For Peggy, housework had become what it should be, "a fine art, and a pleasure to do". ${ }^{178}$ Fears about the burden of housework that Tom shared with Wheeler and The Mirror editor were lifted; housework was no longer drudgery. "The hard housework that our grandmothers used to do is being done to-day in thousands of homes where a magic switch would do it all for them, if they would only let it" declared one Mirror column on 'modern housekeeping'. ${ }^{179}$

They also freed the household from the drama of servants. Peggy concedes that the manual labour involved in housework without modern appliances might be bearable "with the help of a good servant", but Grace has been unable to get a good servant. Annie is her fifth maid that year, and yet her departure is greeted by Grace with relief: "She's gone - and thank goodness too!" she tells her husband. Annie "had been horribly clumsy and impertinent, had had 'words,' and then left her young mistress without compunction".180 New Zealand's 'servant problem' meant servants were hard to find, but it also gave servants a certain degree of power, confident in their abilities to find work elsewhere. There was a perception that this led them to develop an overly demanding or impudent attitude known as 'Servantgalism'.181 The depiction of Annie, who 'has words' with her mistress and leaves after her own clumsiness led to the breaking of an entire tray of crockery, is reminiscent of the way servants infected with servantgalism were portrayed. This disdain for the capabilities of the domestic help available is a far cry from the progressive relationship of compromise advocated in The Mirror's earlier editorial, but it reflects a more positive attitude towards the decline of domestic service. Not only was selfsufficiency a virtue in of itself, but it also eliminated the 'strangers at the hearth', distancing the twentieth century family home from the realm of paid labour and transforming it into a private, family-only domain. ${ }^{182}$ Appliances were a way to escape the difficulties of engaging domestic help without

178 Ibid.

179 'Modern Ways of Housekeeping'.

180 'The Abolition of Home Slavery', p. 30.

181 Elphick, p. 129.

182 Macdonald, 'Strangers at the Hearth', p. 56. 
undertaking the burden entirely on one's self. For Grace, servants are hassles, and she gleefully eliminates them, engaging a whole new staff of 'electrical' servants.

'Labour-saving' was a common theme in The Mirror's domestic advice. The devices and methods they suggested were aimed at increasing the amount of leisure time available to women. "The time that used to be spent in the kitchen has been so reduced that one can find time actually to read books in the morning", commented one article.183 Another argued that lessening the housewife's burden "greatly increased opportunities for the intellectual development of the average wife and mother".184 The truth of this is certainly questionable. Women interviewed by Jean-Marie 0'Donnell for her study on the impact of appliances in New Zealand all agreed that while they made their household work less physically exhausting, the amount of time devoted to it did not decrease. The growing availability of washing machines and vacuum cleaners simply raised standards of cleanliness in the home. ${ }^{185}$ O'Donnell's study begins in 1935, however, when ownership of appliances was more commonplace. In 1926, when The Mirror published its piece on Peggy's modern appliance maintained home, actual appliance ownership was very low, particularly for larger appliances like washing machines and refrigerators. The Mirror's rhetoric around appliances was mostly focused on the untapped potential appliances represented. It was the possibility of appliances, not the reality, that mattered most.

The changing dynamic of home life prompted even more dramatic changes in the configuration of the home space. The Victorian villa, with its narrow corridors and carefully delineated public and private spaces gave way to the informal bungalow, with rooms that opened off one another. Horace L. Massey, R. K. Binney, and W. H. Gummer were all architects who wrote for The Mirror,

\footnotetext{
183 'Modern Ways of Housekeeping'.

184 'Editorial Reflections: Making Housework Easy', The Mirror, September 1928, p. 9.

185 O'Donnell, p. 182.
} 
providing suggestions and plans for the design of the modern house. Massey and Binney both commented on the need to build homes in keeping with modern demands. Binney pointed out the money saved in a smaller, modern house: "There can be little doubt that in the future all of us, except possibly a few, will be living in small houses. The growing burden of taxation and the shortage and difficulty of securing good domestic service and high wages are rendering the proper conduct of a large house an undesirable responsibility". ${ }^{186}$ Massey agreed, arguing that Victorian homes, with their inconvenient distance from kitchen to dining room and furniture designed "as though the turner had set out to produce as must dust collecting surface in their short length as possible" were simply not appropriate for modern life. ${ }^{187}$ "The modern housewife will not put up with the drudgery which the old types of homes necessitated", he wrote. ${ }^{188}$

Kitchens were a source of particularly dramatic change, with The Mirror's architectural correspondents all advocating the abandonment of a separate scullery in favour of a small, but but well planned single room kitchen. This was in keeping with the national trend; old fashioned sculleries were ditched for modern 'kitchenettes', proudly advertised by real estate agents. ${ }^{189}$ W. H. Gummer provided plans for such a kitchen in a Mirror article, 'The Kind of Kitchen A Woman Would Like'. His designs carefully indicate that the size of the kitchen is no bigger than the average reach of a person; a woman working there could reach nearly everything simply by turning on the spot.190 Gummer's plans feature in Helen Leach's study of New Zealand kitchens. Leach comments that while Gummer's kitchen plan is clearly an expensive one, it is notable in that it

186 R. K. Binney, 'Domestic Architecture No. 3', The Ladies' Mirror, March 1924, p. 22.

${ }^{187}$ Horace L. Massey, 'Better Homes for New Zealand: Suggestions from England and America', The Ladies' Mirror, November 1922, p. 14.

188 Ibid, p. 15.

${ }^{189}$ Helen M. Leach, 'The European House and Garden in New Zealand', in At Home in New Zealand: History, Houses, People (Wellington: Bridget Williams Books, 2000), p. 55.

190 W. H. Gummer, 'The Kind of Kitchen A Woman Would Like', The Lady's Mirror, July 1922, p. 26. 
is planned for the lady of the house, and not her cook; its compact size allows room for only one worker. ${ }^{191}$

These new layouts were labour-saving devices in themselves, and small changes could be implemented without entirely refitting the family home. The Mirror instructed readers on how to streamline their kitchens, simply by rearranging the contents. In one 'In the Kitchen' column the author and her friends eagerly discuss their kitchen of their new neighbour. Mrs Newlywed's kitchen has "almost everything you can think of in the labour-saving way", but what is described is not appliances, it is the dish rack above her sink, the easy to clean oil cloth on her kitchen table, the placement of her cooking utensils so they are always close to hand. ${ }^{192}$ Another article explains how the author has set up their kitchen into 'food preparation groups' and 'clearing groups' so that the amount of moving around the space is minimised. ${ }^{193}$ Those starting from scratch should pay attention to simple things, like the height of the sink and workbenches. Gummer stressed that ideally nothing in the kitchen should have legs, as to raise the stove or workbench off the floor simply created a space that was difficult to clean. ${ }^{194}$ In The Mirror, housewives were encouraged to rethink their approaches and their spaces, to rework their way of doing things for optimum efficiency. The modern home was one which was carefully designed to maximise comfort and reduce work.

The modernisation of home life was not limited to the home itself, however. Tied to women's domestic role was their role as mothers, and motherhood too was subject to modernization and expert scrutiny. Infant welfare became a priority through The Royal Society for the Health of Women and Children, more commonly known as Plunket. Plunket was established in 1907, but it was during the 1920s that its influence over New Zealand mothers became widespread. "We're getting very proud of Sir Truby King, who seems,

\footnotetext{
191 Helen Leach, Kitchens, p. 76.

192 Melanie S. Primmer, 'In the Kitchen', The Mirror, August 1928, p. 73.

193 'Mr. and Mrs. Architect', The Ladies' Mirror, June 1925, p. 38.

194 Gummer, p. 27.
} 
indubitably, to be able to turn out the best babies at the least expense, like Henry Ford with motor cars", wrote one Mirror columnist on the opening of the new Wellington Karitane Hospital. ${ }^{195}$ The comment was tongue-in-cheek, but Plunket certainly did advocate a more regulated, scientifically approved system of care for babies. The 'Plunket System' involved a carefully maintained routine, with regular feeding. It also involved regular check-ups with the Plunket nurse, in which baby was weighed and his or her progress recorded, and mothers received support and advice. A more serious Mirror article on the organisation viewed the work of the society with approval:

No longer is any woman expected to rear her children by instinct; the resources of science are at her disposal, she is asked to take nothing on trust, and methods and systems tried a thousand times and under all conditions are ready to her hand under the guidance of a band of devoted women, for whom no praise could be adequate. 196

Modern motherhood was not left to women's innate nurturing instincts, but proceeded with the aid and supervision of medical experts - with impressive results. The infant mortality rate was reduced from 40.57 per 1000 births in $1906-1910$ to just 9.5 by 1936-1940, and New Zealand could proudly claim to have the lowest infant mortality rate in the world. ${ }^{197}$ The degree to which the Plunket Society itself was responsible for this decline has since been challenged, but at the time it was often thought to be the primary cause. ${ }^{198}$ Plunket's success was proof of the efficacy of modern methods.

The decrease in infant mortality was matched by a decrease in family size. The average family size for women who married in 1924 was just 2.4 children, as

195 'Breezes from the Capital', The Mirror, April 1927, p. 14.

196 'Editorial Reflections', The Ladies Mirror, January 1923, p. 4.

197 Linda Bryder, A Voice For Mothers: The Plunket Society and Infant Welfare 1907-2000

(Auckland: Auckland University Press, 2003), p. x.

198 Philippa Mein Smith, 'Infant Welfare Services and Infant Mortality: A Historian's View',

Australian Economic Review, No. 93, 1991, pp. 22-34. 
opposed to 6.8 for the woman of 1880.199 Women were clearly taking steps to limit their families, but evidence indicates that most of the birth control methods practiced by New Zealand women at this time were unsophisticated. Condoms and pessaries were expensive and difficult to procure, as were cervical caps. Many women relied on non-mechanical methods such as withdrawal and the rhythm method, or they produced their own homemade pessaries. ${ }^{200}$ Information was difficult to come by. The Sex Hygiene and Birth Regulation Society (now Family Planning) was not established until 1936 and even then faced strong opposition; the New Zealand Post Office seized their pamphlets as 'obscene material', and few publications aside from the feminist magazine Woman To-Day were willing to publish information on their work. In the $1920 \mathrm{~s}$ books that provided information about birth control, such as Ettie Rout's Safe Marriage and Marie Stopes' Married Love were denied entry to the country by customs officials. ${ }^{201}$

The Mirror certainly did not publish information about birth control methods, but it did allow members of the public to air their views on its use within wider conversations about public health and sex education. In 1924 it published an article by F. Martyn Renner of the White Cross League, an organisation which sought 'social purity' and "the creation of higher tone of public opinion upon what are commonly understood as sex questions".202 Renner was contributing to a Mirror mediated discussion about sex education, and argued that while frank sex education was important, it should discourage the use of birth control. Renner believed that "artificial limitation of families must, if adopted on anything like a large scale, result in a moral loss to the community" and that "we,

199 Erik Olssen, 'Towards A New Society', in W. H. Oliver (ed.), The Oxford New History of New Zealand (Wellington: Oxford University Press, 1981), p. 258.

200 Barbara Brookes, 'Reproductive Rights: The Debate Over Abortion and Birth Control in the 1930s', in Barbara Brookes, Charlotte Macdonald and Margaret Tennant (eds.), Women in History: Essays on European Women in New Zealand (Wellington: Allen \& Unwin, 1986), pp. 121 122, Philippa Mein Smith, Maternity in Dispute: New Zealand, 1920-1939 (Wellington: Historical Publications Branch, Department of Internal Affairs, 1986), pp. 110-111.

201 Mein Smith, Maternity in Dispute, p. 111.

202 'The White Cross League', Otago Daily Times, 29 January 1906, p. 4; F. K. Prochaska, Women and Philanthropy in Nineteenth Century England (Oxford: Clarendon Press, 1980), pp. 214-216. 
as members of the Anglo-Saxon race, cannot regard as a matter of indifference whether the unfilled portions of the world shall be peopled by our own descendants, or by Eastern races, or by negroes, or by European or Slavonic races." ${ }^{203}$ Renner's arguments were not unique. Many were concerned about the declining birth rate, and New Zealand's medical professionals were generally opposed to birth control, with Dr Truby King declaring that Plunket and the state should do all they could to increase family size, not diminish it. ${ }^{204}$

Disagreeing with Renner, however, was E. W. Flint, who wrote in to The Mirror in response to an article the magazine published on the maternal mortality problem. Flint criticised the article for not mentioning the correlation between maternal health and family size, and argued that open access to birth control was crucial to women "who have already brought into the world as many mouths as they can do justice to, and which comprise as large a family as they can attend to and keep their own health". ${ }^{205}$ In Flint's eyes, the mother who could not control her fertility risked becoming "the all-too-common household drudge and childbearing machine so many women are". 206 Once again, modern solutions were presented as the answer to the overbearing burden of household labour. Smaller families were easier for women to look after, as well as being better for the health of both mother and child. While Renner's arguments about the health of the race were commonly voiced concerns of the period, Flint's argument is perhaps more representative of the majority of women who quietly continued to limit their families. As another Mirror writer acknowledged, the desire to limit family size generally came from "the prudent resolution... to bring no more children into the world than they can afford to maintain in decency and comfort, to feed, clothe, and educate on something like a civilised pattern".207

\footnotetext{
203 F. Martyn Renner, 'The White Cross League in its Relation to Education and Public Health', The Ladies' Mirror, July 1924, p. 20. 204 Mein Smith, Maternity in Dispute, p. 110.

205 E. W. Flint, 'Maternal Mortality and Birth Control: A Note on the Article Which Appeared our September Issue', The Ladies' Mirror, November 1924, p. 27.

206 Flint.

207 Charles Pilley, 'Those Missing Babies', The Mirror, May 1927, p. 43.
} 
Renner's comments on birth control were part of a wider discussion about sex education that took place in The Mirror. This was a question of pressing concern during the period; there was a sense that modern times necessitated a different approach from what had been the norm. The magazine's perspective was that the era of ignorance and prudery was over; children should be taught about sex, but exactly what to teach them and how to approach it was a more difficult question. In July 1924, it announced its intentions to publish a series of articles about the sex education question from a variety of viewpoints, so that New Zealand mothers could have the best possible knowledge to decide what was best for their child. ${ }^{208}$ Renner's was the first. Despite his disapproval of birth control he was strongly in favour of frank sex education. He drew a clear line between inadequate sex education and the spread of venereal disease and illegitimate children and argued that only through sex education could young people be taught proper moral values around sex. ${ }^{209}$ There was a growing perception that remaining silent on sex matters was not only no longer possible, it could be harmful. An article originally written for Woman by Major Theodore Faithfull appeared in the November 1926 issue of the Mirror, and drew attention to the danger of children finding out about sex in the wrong way:

The whole sex idea, instead of striking the youthful mind as one of the pure and beautiful things of life, becomes shameful and unhealthy. It comes as secret, forbidden knowledge. The sudden revelation upsets the immature mental balance. It assumes a disproportionate importance in the mind. ${ }^{210}$

The Mirror encouraged parents to be frank with their children, to answer their questions about sex and reproduction honestly and without undue ceremony. "At one time we had some bantam chickens, and when, one day, our little girl

\footnotetext{
208 The Editor, 'The Question of Sex Education', The Ladies' Mirror, July 1924, p. 20.

${ }^{209}$ Renner, pp. 20-21.

210 'Bringing Up the Young Idea', The Mirror, November 1926, p. 60.
} 
asked us what the rooster was chasing the hen for, the opportunity was given us, and we took advantage of it" explained one mothercraft column. ${ }^{211}$

These questions took on greater significance as a growing awareness of psychology seemed to heighten the consequences of getting it wrong. Truby King may have provided a convincing solution to the problem of infant mortality, but the theories of Freud and his peers introduced parenting problems no one had even considered before. According to one Mirror article, "too many children reach puberty now in a more or less neurotic state", and these neuroses were developed in childhood, the direct result of their parental influence. ${ }^{212}$ Another article explained how a negative family environment could upset the delicate psychology of the child with real patient examples:

The mother, as a result of her reaction in childhood to her own father, was an expert at nagging and quarrelling, her husband and youngest daughter (the patient) bearing the brunt of it in the home. As a result, the patient was found, under the assumption of a reserved manner, to be in as great a state of emotional turmoil as the little girl of seven, the stammer being merely an outward sign of her inability to give any expression to the seething tumult within her. ${ }^{213}$

Parental responsibilities went beyond simply feeding and clothing the child. Failure to provide the right kind of home environment could cause long term psychological damage, and as this mother shows, damage done could be passed on to the next generation - an unhappy child would themselves become a poor parent. The Mirror offered solutions, however. Dr Buckley Turkington, an Auckland psychologist and medical advisor to the National Council of Women, 
contributed a specially written article to The Mirror on 'The Mind of the Child', which explained to readers how mental 'abnormalities' develop in children. ${ }^{214}$

Modern children needed modern parenting methods, and The Mirror was happy to provide suggestions. Its Mothercraft column sought to provide readers with modern parenting advice, helping them avoid psychological damage. Certainly the relationship between parent and child was perceived to be less formal than it had been in the Victorian age, although whether or not this was a good thing was a matter of some debate. Mothercraft articles in The Mirror often argued that a more friendly relationship was a good thing, and that parents who were frank and honest with their children would earn their respect and trust. These parents should be open minded, and not expect their children to behave as they themselves had done: "The mother of a modern daughter should, if possible, be modern in her outlook. An old-fashioned mother is bound to receive many shocks from an up-to-date daughter and the easiest way to avoid them is to be up to date, too". 215 But others argued that modern children were given too much freedom, and such parents risked raising spoiled children with no sense of duty or obligation. They argued that habits formed early in life would be the habits of the adult, and it was never too early to start training children in obedience. ${ }^{216}$

The modern world provided domestic women with new tools and knowledge, but it also undermined the belief in domestic skills as innate qualities of women. The Plunket Society stressed that "proper care of baby is an art not an accident", and Miss Partridge, Plunket secretary, told The Mirror: "One wishes one could believe a little more in the 'mother instinct'... but the number of poor little wrecks that may be seen any day at our rooms proves that this so-called 'mother instinct' is nothing but a sad delusion". ${ }^{217}$ Many expressed dismay that modern times had led to deterioration in women's domestic skills, arguing that

214 Dr. Buckley Turkington, 'The Mind of the Child', April 1927, pp. 72-74.

215 Miss Eva Moore, 'Modern Daughters', The Mirror, November 1926, p. 52.

216 'Mothercraft: The Rights of Childhood', The Ladies' Mirror, July 1923, p. 34.

217 'The Plunket Society: What It Is Doing', The Ladies' Mirror, August 1922, p. 9 
because the modern woman no longer served a domestic apprenticeship in her mother's home, but spent her youth in the classroom and working as a typiste or shop assistant, she had no longer had the opportunity to absorb the necessary skills for maintaining a home. An article discussing women's domestic abilities said that "many young women nowadays know considerably less about making a fire, tidying a room and preparing a simple meal than does the average boy scout".218 But others suggested the way one's mother taught one to do something should no longer be assumed to be the best way, and encouraged all women to consider new approaches to domestic skills. The modern young woman who was willing to adopt new methods, like 'Mrs Newlywed' and her labour saving tricks, could run a more efficient home than the woman who did not question traditional ways of doing things.

Women's own knowledge, inherited or innate, became secondary to scientific, expert knowledge. Dr Buckley Turkington, the child psychologist, and architects Gummer, Binney and Massey are two already discussed examples of the kinds of experts The Mirror could connect its readers with. Plenty of other doctors from a variety of fields also wrote for The Mirror, including Dr Truby King himself.219 Melanie Primmer, who edited The Mirror's 'In the Kitchen' section from 1928, was also the author of The Up-To-Date Housewife, a book of recipes and 'family hints' aimed at the modern, servantless New Zealand housewife. ${ }^{220}$ Her columns provided Mirror readers with advice on the running of the kitchens. While they were told in a friendly, conversational style, The Mirror never hesitated to stress her authority on the subject, drawing attention to both her degree and her book in the column's by-line. Commercial products also helped bridge the gap. The formula of Edmonds' 'sure to rise' baking powder promised results to even the most hapless of newlyweds, helping 'Miss

218 'Domesticated by Order: Compulsory Training for Women', The Ladies' Mirror, June 1924, p. 27.

${ }^{219}$ Dr Truby King and Miss A. Pattrick, 'The Maternal Mortality Problem: Its Cause and Cure', The Ladies' Mirror, August 1924, pp. 27-28, 31.

${ }^{220}$ Melanie S. Primmer, The Up-To-Date Housewife: Recipes, Food Suggestions and Family Hints for All Occasions (Dunedin: Coulls Summerville Wilkie, 1926). 
Office' become 'Mrs Cook'.221 The Mirror suggested new, modern approaches for women backed up by science rather than tradition.

The faith placed in these technological and scientific developments to provide domestic efficiency and happiness has often been viewed with a high degree of cynicism. Feminist retaliation in the 1960s and 1970s to women's domestic role as an oppressive patriarchal institution has meant that the development of the modern housewife's domain has often been viewed as sinister. It is perhaps this attitude that caused Hamilton to associate The Mirror's domestic content with conservatism. When aware of the discontent that came later, the advice that The Mirror provided could easily seem regulatory, enforcing ever-higher standards and preoccupied with productivity. Many historians have viewed domestic modernity in this light. Olssen's 1981 study of Plunket, for example, views the society as a means of inculcating the children of the nation with middle-class values of self-discipline and control.222 ${ }^{\prime}$ 'Donnell notes that greater use of household appliances belonged to a period in which women were tied more strongly to home, and any new-found leisure time was encouraged to be devoted to other domestic pursuits. ${ }^{223}$

However, The Mirror's domestic advice does not always support these conclusions. While The Mirror valued women's domestic role, it never suggested that the home should be their only concern. As discussed in the previous chapter, The Mirror was open to the idea that not all women desired the role of wife and mother, and could instead live rich and fulfilling lives outside the domestic sphere. But even those that did have domestic responsibilities should not be limited to them. Primmer's 'In the Kitchen' column advised readers to cultivate outside interests: "Do not let yourself grow into a Martha, absorbed with the kitchen and all it stands for in life". ${ }^{224}$ Instead,

221 'Edmonds Baking Powder' Advertisement, The Ladies' Mirror, July 1922, p. 23.

222 Erik Olssen, 'Truby King and the Plunket Society: An Analysis of a Prescriptive Ideology', New Zealand Journal of History, Vol. 15, No. 1, 1981, pp. 3-23.

223 O’Donnell, pp. 182-183.

224 Melanie S. Primmer, 'In the Kitchen', The Mirror, February 1929, p. 75. 
readers should join the local women's club, take up a sport, or get involved in a charity. Mothers were encouraged to allow themselves space from their children. 'In the Kitchen' regularly suggested that mothers take time to themselves to rest each day, and that their children were taught not to disturb them. In 1924 The Mirror published an article which argued for the necessity of crèches in New Zealand's town centres, so that mothers could have time to themselves to shop, meet friends, or even go to the cinema. "Babies are very beautiful 'ties' - but 'ties' none the less, and every modern woman of keen intellect will appreciate her children and home more, and do both greater justice, if just occasionally she may have an hour of her very own, for the welfare of her own individuality", explained the author. ${ }^{225}$ Woman's role as wife and mother was important, but she should not sacrifice everything for it. Time to herself was also important, as was the development of her own, personal, identity outside the home.

In more recent years, historians have begun to suggest that we think more carefully about what developments in the home meant to mothers and wives of the time. Linda Bryder has disagreed with Olssen's depiction of Plunket as an inherently prescriptive organisation, stressing instead the importance of the organisation to mothers who sought advice and support.226 Julia Giles has commented that "for many women, domestic modernity appeared to offer the dignity and self-esteem that was so often perceived as missing from the lives of their mothers and grandmothers". 227 In The Mirror the modern housewife, with her domestic appliances and small, manageable family, is consistently presented in stark contrast to the Victorian woman, overburdened with household drudgery. Rather than conservative or traditional, her role was revolutionary and transformative. Many women would come to find that the troubles of home life could not be magically solved by electricity or child

225 'A Day Nursery For Our Babies', The Ladies' Mirror, May 1924, pp. 19-20, 42.

${ }^{226}$ Linda Bryder, 'Perceptions of Plunket: Time to Review Historians' Interpretations?', in Linda Bryder and Derek A. Dow, New Countries and Old Medicine: Proceedings of An International Conference on the History of Medicine and Health, Auckland, 1994, pp. 98-102.

227 Giles, p. 11. 
psychology, but in 1932 the possibilities still seemed endless. In The Mirror, modernity promised to make women's lives better, providing them with new home comforts, unlocking the mysteries of parenthood, and freeing them from drudgery. 


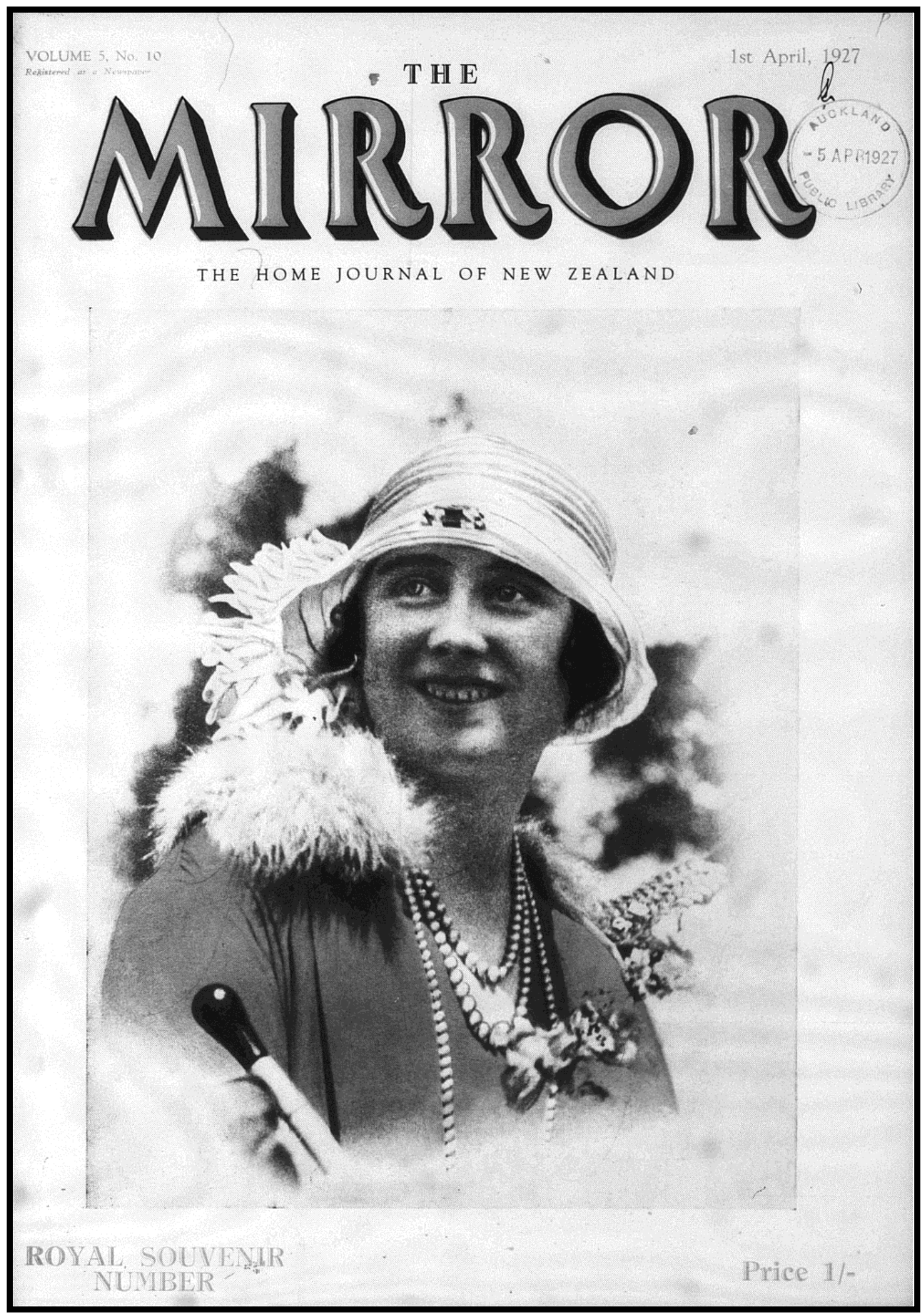

Cover of The Mirror's 'Royal Souvenir Number', featuring the Duchess of York, April 1927. 
4.

\section{Imperial Modernity: The Mirror and the 1927 Royal Tour}

In 1927 the Duke and Duchess of York embarked on a royal tour of Australia and New Zealand. The Mirror, along with the rest of New Zealand, joyfully celebrated their visit, publishing not one, but two special commemorative issues. The Mirror was a publication which generally speaking, embraced modernity, and its enthusiastic celebration of the royal family prompts consideration of how those conservative institutions of monarchy and empire fit within the modern New Zealand of the 1920s. Charlotte Macdonald has written of the discomfort New Zealand historians have expressed at the "continued hanging on to British apron strings" during the interwar period. ${ }^{228}$ Such imperial deference may seem at odds with a modern nation, but New Zealand's emerging sense of nationhood during this period was consistently embedded in continued loyalty to King and Empire. The bright future looked forward to in The Mirror was one in which the British Empire continued to have an integral part.

Visiting New Zealand in the 1927 royal tour was the Duke of York, Prince Albert, the second son of the then reigning King George V, and his wife, the Duchess of York. Albert would go on to become king as George VI, and the Duchess is better known today as the Queen Mother, a title she held for most of the latter half of the twentieth century after her daughter Elizabeth acceded the throne. The 1927 tour followed one in 1920 by Edward, the Prince of Wales and the Duke of York's elder brother. Edward was well known for his charming and debonair character, and he had apparently made a strong impression on the young women of New Zealand, one The Mirror doubted Albert could top: "We shall see whether the Duke will oust his brother in the affections of New Zealand flappers; but this is hardly likely - a married man has his 
limitations". ${ }^{229}$ Albert was a more reserved figure, possessed of an unfortunate stammer and far less interest in the spotlight; he also lacked the glamour that came from being next in line to the throne. But being a married man had its benefits too; the Duke's new wife was wildly popular, and the birth of their first daughter, the Princess Elizabeth, in 1926, had completed his transformation from slightly boring younger brother to upstanding family man. The royal family commanded widespread fascination, even outside the bounds of British Empire.

The excitement and novelty of their visit no doubt goes some way towards explaining the tour's prominence in The Mirror, but the royals also represented an important link with Britain. In Britain itself, royal support became, according to Tom Nairn, a key dimension of domestic British nationalism. ${ }^{230}$ For those British citizens living in various outposts of empire, the presence of the monarch could take on even deeper meanings. Alison Clarke, writing on various royal celebrations in nineteenth-century Otago, draws attention to the monarchy's ability to draw together what was a highly diverse community in near universal support.231 The Mirror considered the royal tour to be an "imperial pilgrimage": "The Duke comes amongst us as an Ambassador of Empire and his tour cannot but have momentous results in consolidating the spirit of unity and fostering those inexpressible sentiments that bind the farflung units of Greater Britain to the Motherland". ${ }^{232}$ Charles Reed, in his discussion of the 1901 royal tour of South Africa suggests "the royal tours offer a fascinating lens through which to write a global history of loyalism and

\footnotetext{
229 'Echoes of the North', The Mirror, October 1926, p. 8.

230 Tom Nairn, The Enchanted Glass: Britain and its Monarchy (London: Radius, 1988).

${ }^{231}$ Alison Clarke, "With One Accord Rejoice on this Glad Day": Celebrating the Monarchy in Nineteenth-Century Otago', The New Zealand Journal of History, Vol. 36, No. 2, 2002, p. 138. 232 'In The Mirror', The Mirror, March 1927, p. 6.
} 
Britishness in the British Empire".233 The Mirror's coverage of the royal tour is an opportunity to consider these themes within interwar New Zealand.

The public presence of the royal family could also be a reassuring presence to those living in a newly modern world, as others have noted. The monarchy, as an age-old institution, was a symbol of stability and endurance. David Cannadine has argued that much of monarchy's claim to tradition was an illusion; many of the rituals perceived to be ancient were in fact recent nineteenth-century inventions. Nevertheless, during the early twentieth century these rituals of the British monarchy (including those which occurred on imperial tours) functioned in the public mind as "a unique expression of continuity in a period of unprecedented change". 234 Becky Conekin, Frank Mort and Chris Waters open their discussion of modernity in Britain with the 1953 coronation of Elizabeth II, arguing that this was a defining moment of British postwar modernity, which both invoked the greatness of the past and promised a fresh start for the future. Here the Queen acted as the figurehead of a nation with a proud history and a bright future, and the anchor for a new modern empire - the Commonwealth. ${ }^{235}$ Conekin et al's discussion of Elizabeth's coronation is therefore rooted in a very specific postwar context of imperial dissolution and national reconstruction, but the idea of the monarchy as an anchor during a period of change is one which is visible in the earlier interwar content of The Mirror.

The enduring presence of the monarchy provided reassurance in modern times, but the influence of the royal family was itself also shaped by new, modern means of transmission. The invention of television allowed Elizabeth's

${ }^{233}$ Charles V. Reed, 'The Royal Tour of 1901 and Imperial Citizenship in South Africa', in C. McGlynn, A. Mycock and J. W. McAuley (eds.), Britishness, Identity and Citizenship: The View From Abroad (Bern: Peter Lang, 2011), p. 12.

${ }^{234}$ David Cannadine, 'The Context, Performance and Meaning of Ritual: The British Monarchy and the 'Invention of Tradition', c. 1820-1977', in Eric Hobsbawm and Terence Ranger (eds.), The Invention of Tradition (Cambridge University Press, Cambridge, 1983), p. 139.

235 Becky Conekin, Frank Mort and Chris Waters, 'Introduction', in Becky Conekin, Frank Mort and Chris Waters (eds.), Moments of Modernity: Reconstructing Britain 1945-1964 (London: Rivers Oram Press, 1999), pp. 1-2. 
coronation to be watched at home by over twenty million people in Britain and even more across the empire (although not in New Zealand), and stories of families crowded around brand new television sets often feature as heavily in accounts of the event as the coronation itself. Conekin et al see the public broadcast as an important component of the event's significance, commenting that "through television, the crowning of the Queen became both a world event and a peculiarly intimate drama, for this public spectacle could now be consumed by audiences in the domestic setting of the home". ${ }^{236}$ Personal consumption of royalty occurred long before television however. The first mass-produced commemorative pottery had begun to appear in the late nineteenth century, and British companies like Cadbury and Oxo cashed in on public interest by producing their own royal memorabilia. ${ }^{237}$ From 1932, the King's 'Christmas Broadcast' directly addressed his many imperial subjects through the radio in their own homes. ${ }^{238}$ In the 1920 s, however, it was photography and increasingly economical photographic reproduction which had most transformed the public's connection to their monarchs. The widespread use of photographs and the cheap pictorial press greatly enhanced the accessibility of Britain's royals. ${ }^{239}$ By the 1920s photographs of the royal family were common and Edward, the Prince of Wales, was one of the most photographed personalities of his day. ${ }^{240}$ These images were widely disseminated in newspapers, and, notably, women's magazines.

Royalty has long been a feature of the women's magazine. Discussion of the royals can be found as far back as the eighteenth century, when early women's periodicals often included discussions of royal ladies. These were, however, largely 'society' journals, and represented royals primarily as "distant, beautiful,

\footnotetext{
236 Ibid, p. 2.

237 Cannadine, p. 137.

238 Philip Murphy, Monarchy and the End of Empire: The House of Windsor, the British

Government and the Postwar Commonwealth (Oxford: Oxford University Press, 2013), pp. 22-23. ${ }^{239}$ Cannadine, p. 111; Ballaster et al, p. 72.

240 Lewis Broad, The Abdication: Twenty Years After (London: Frederick Muller, 1961), p. 5.
} 
objects of fantasy". ${ }^{241}$ In the late nineteenth century the availability of images of the royal family transformed them into familiar figures. Their presence in women's magazines began its shift to the now common rhetoric "that locates the royal family as an extension of the 'family' of the magazine and its readers well-known, much loved, and fallible human beings". ${ }^{242}$ By the twentieth century pictures and stories about the royal family were a common feature of the modern women's magazine, and they had substantial commercial impact. Janice Winship notes their power in her discussion of women's magazines, describing how the British magazine Woman's Own, in 1950, gained 500,000 sales overnight simply by publishing a story by 'Crawfie', the governess of Princesses Elizabeth and Margaret.243 In 1924 The Mirror also used the royal family to make a push for sales, promising every subscriber during the month of May a framed and autographed photographic portrait of the Prince of Wales. In July they apologised to those who had still not received their portrait; demand had outstripped supply.244 The royal family had the power to entice readers like nothing else.

The Mirror offered its readers an inside view of the royal family's life with a series of articles called 'Royalty in Reality'. Written by an anonymous "Court Historian", these articles promised an inside view on the royals' lives. They argued that one could not get a sense of their true selves based only public appearances, as the article on Queen Mary made clear:

To have seen the Queen robed and be-jewelled on a State occasion, forming, without any conscious effort, the central figure of the scene, is to have observed only a wonderfully impressive personage. To

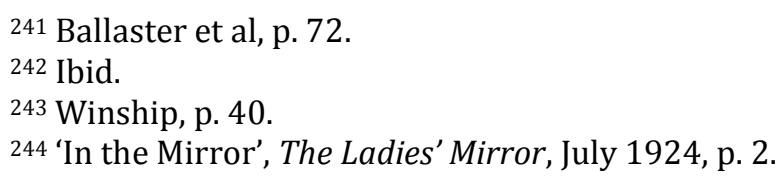


know Queen Mary as she is, one must see her in the home circle where always she is happiest. ${ }^{245}$

The article, entitled 'A People’s Queen', emphasised the Queen's domestic role. It described her efforts to cut costs in the palace kitchen, presenting her as a skilled housekeeper with an admirable frugality. The Queen, it argued, looked upon the nation "as one large family in which it is her duty to display those virtues which shed a sacred light on the office of wife and mother". 246 The King was also displayed in a domestic setting, with The Mirror's 'Court Historian' arguing that his home life was little different from that of the magazine's readers:

Indeed, save for the more elaborate surroundings, many an evening at Buckingham Palace and Sandringham is very similar to an evening in any middle-class home where the family is united in real affection. The King smoking, reading or talking; the Queen, perhaps, at needlework, two of the Princes playing billiards or chess, or entertaining the company with a little music... When the historian writes the story of the eventful times of King George, he will record not only that the King-Emperor moved amid momentous events, and proved himself equal to those events, but that he set before his subjects and example of happy domesticity and family life: that he was not only a great King, but also a model husband and father, and a great-hearted, human man. ${ }^{247}$

The King is presented as a patriarch, not only of a nation and an empire, but of his family. The King was a great leader, but he was also 'just like us', his family life a model of middle-class domesticity. The 'Royalty in Reality' series drew The Mirror's readers closer to the royal family, allowing them to feel a much more p. 45 . 
intimate relationship with their monarch. It also allowed The Mirror to position itself as the publication with the truth about the royals, disputing what people thought they knew about them and presenting them 'in reality'.

The depiction of the royal family as an exemplary model of family life was not new. Queen Victoria had also been depicted as an ideal of domestic womanliness by the nineteenth century women's periodicals. ${ }^{248}$ But the royal family could also be modern, in their own way. Their ability to adapt was reflected in the very make up of the royal family itself, as the Duchess, while the daughter of a Scottish earl, was not born royalty. The Mirror presented her marriage to the King's second son as evidence of the fading "traditional idea that our monarchy should find it incumbent to make matrimonial alliances with alien princes and princesses to uphold the prestige of royalty". ${ }^{249}$ The Prince of Wales' bachelor status was similarly a sign of royal progress: "It is true that Royalty used to marry early in life, but many Royal traditions have changed in recent years. Princes have greater freedom in their private arrangements and are allowed to plan their lives like ordinary men."250

The royal family was modern, but they were modern on their own terms. When discussing the Duchess, The Mirror's Court Historian carefully distinguished her from other women:

She dislikes smoking and most of the habits of those who call themselves 'modern' women. And yet, withal, the Duchess is modern. She is ever ready to learn and to adopt such new modes as are consistent with her ideals and with her conception of the feminine part in life. 251

The Duchess was prepared to move with the times, but she remained discerning in what modern habits she adopted. The royals engaged in modern life, but

\footnotetext{
248 Beetham, pp. 162-163.

249 'In the Mirror', The Mirror, March, 1927, p. 6.

250 A Court Historian, 'Royalty in Reality: Our Gay Prince', The Ladies' Mirror, May 1925, p. 35.

251 A Court Historian, 'The Happy Duchess', The Mirror, July 1925, p. 12.
} 
remained aloof, leaders, rather than followers of fads. The Prince of Wales was a noted trendsetter, credited in The Mirror with influencing men's fashion even in America, outside the imperial sphere. ${ }^{252}$ Another article, a slightly farcical account of an exchange between the writer and her husband on the state of men's dress today, concluded when the husband told the writer she should send her suggestions to the Prince, for as "the world's leader in men's fashion", only he had the power to change things. ${ }^{253}$

The Mirror's extensive royal content exposes the power the royal family had to influence and entice readers in the modern New Zealand of the twenties, but while the royal family was becoming ever more popular in the realm of the women's magazine, the power of the empire they represented was waning. At the time of the royal visit, New Zealand was no longer a colony but a 'dominion', a status it obtained in 1907. In 1926 the Balfour Declaration acknowledged the equal status of these dominions, no longer subservient to Britain but partners in a voluntary community of empire. The 1931 Statute of Westminster legally formalised their independence, rescinding Britain's right to legislate for its selfgoverning former colonies. ${ }^{254}$ Despite these changes, New Zealand's allegiance to empire remained strong. James Belich argues that in fact New Zealand's dominion status came in the middle of a period of 'recolonisation', in which the nation's links to Britain were strengthened both economically and culturally. ${ }^{255}$ According to John Darwin, "Dominionhood was not the most that the Dominions could extract from the grudging Imperial centre: it was the most that the internal politics of the Dominions themselves would permit". 256 New Zealand politicians of the early twentieth century generally expressed dismay rather

252 Evelyn Graham, 'The Prince Almost Sets Odd-Socks Fashion', The Mirror, January 1930, pp. $69,71$.

253 'Cowards All: A Short Story by Sybil of the Short Skirt', The Mirror, December 1927, p. 61.

254 John Darwin, 'A Third British Empire? The Dominion Idea in Imperial Politics', in Judith M. Brown and WM. Roger Louis (eds.), The Oxford History of the British Empire Vol. IV: The Twentieth Century (Oxford: Oxford University Press, 1999), pp. 68-69.

255 James Belich, Paradise Reforged: A History of the New Zealanders from the 1880s to the Year 2000 (Auckland: Penguin Books, 2001), pp. 53-77.

256 Darwin, p. 71. 
than excitement at the prospect of increasing independence from Britain, and the Statue of Westminster was not adopted into New Zealand law until 1947.257 Here, politicians and leaders worked to protect the nation's link with Britain, believing as they did so that they were responding to the will of the people. ${ }^{258}$ New Zealand, perhaps most of all the dominions, had little interest in independence. In these changing times, royal tours offered a reassuring recognition of the bonds of empire, a reminder that the monarch still cared about his more distant territories.

In February 1927 The Mirror's first 'Special Royal Number', was published in anticipation of the Duke and Duchess' arrival. It prepared readers for their arrival, with the return of 'A Court Historian' to provide insights about the real personalities of both the Duke and Duchess. Another article helped the reader get to know the Duchess by describing 'A Day With a Duchess'. The Mirror's fashion column discussed the Duchess's style and made predictions about her "dominion trousseau". 259 Alongside these privileged insights into royal life were a host of images to help the reader visualise the royal visitors and their family. The entire issue was littered with portraits of the royal family: the Duke and Duchess, the King and Queen, the Prince of Wales, and christening photos of the baby Princess Elizabeth. Local preparations were also covered, and the regional columns discussed local excitement as New Zealand's town centres prepared themselves for the royal arrival.

The second issue, the 'Royal Souvenir Number', was published after the visit, and gave details about the trip. It included stories of the tour from around New Zealand, supplemented by a large number of images. The Duke and Duchess had arrived in Auckland on February 22 1927, travelling on the HMS Renown. They travelled down the North Island, meeting with Māori leaders in Rotorua

257 Angus Ross, 'Reluctant Dominion or Dutiful Daughter? New Zealand and the Commonwealth in the Inter-War Years', Journal of Commonwealth Political Studies, Vo. 10, No. 1, 1972, pp. 28-44. ${ }^{258}$ Harshan Kumarasingham, 'Independence and Identity Ignored? New Zealand's Reactions to the Statute of Westminster', in National Identities, Vol. 12, No. 2, 2010, p. 149.

259 'Vanitas Vanitatum', The Mirror, February 1927, pp. 21, 23. 
and fishing on the Tongariro River. In Wellington the Duchess opened the new Karitane hospital and the Duke made an unscheduled visit to the workingmen's cottages in the Hutt Valley. They continued on to the South Island, but the Duchess fell ill in Nelson, and the Duke had to continue alone, a fact for which The Mirror blamed the excessive number of boring official functions the Duke and Duchess were forced to suffer through during their tour of the North Island.260 Overall however, The Mirror viewed the tour as a success for the royals. It was the Duchess that had particularly impressed:

To say that the Duchess captivated the heart of New Zealand is to express a mere commonplace. By her womanly grace, her vivaciousness, and her entrancing personality she immediately won the esteem and affection of our people, and no one can fail to appreciate what an acquisition this dainty Scottish lass has been to the Royal Family of England.261

The Duchess was incredibly popular with the public, and it was her picture that graced the cover of both special royal issues, as well as several other issues of The Mirror. When she was unable to continue with the tour in the South Island the Duke supposedly saw little point in continuing the tour, as no one would turn out to see him alone. ${ }^{262}$ He was wrong of course, but the disappointment felt is evident in The Mirror's 'South of the Straits' column.

One article went into particular detail about the Duke and Duchess' time in Rotorua. The Mirror told of how the Duke and Duchess were shown around Rotorua by a Māori guide, who is described as being of "high Maori birth" but given only the name Bella. It seems likely that she was Bella Papakura, a wellknown Rotorua guide and local leader. The Mirror described the Duchess' encounters with Bella and another Māori woman:

\footnotetext{
260 'In the Mirror', The Mirror, April 1927, p. 6.

261 'In The Mirror', The Mirror, March 1927, p. 6.

262 Valerie Davies, Royal Tourists: 120 Years of Royal Visits to New Zealand (Auckland: Random House, 1989), p. 43.
} 
A Maori woman of good birth from the South Island, thickly tattooed about the mouth, was walking towards them. As soon as she saw the Royal visitors, she made all manner of strange grimaces. More and more horrible they became in her strenuous efforts, but the Duchess still smiled. This incident evidently remained in her mind. Afterwards she asked Bella to explain the Maori greeting, and Bella eagerly told her that it was customary to make grimaces. The uglier the grimace the more heartfelt was the greeting. "I thought that must be so," said the Duchess. ${ }^{263}$

The Duchess is presented here as a natural leader, who has gained the respect of her Māori subjects and responds to their strange behaviour with sensitivity and grace.

During the royal tour Māori were expected to act as a unique local spectacle, but The Mirror was also careful to present Māori as loyal imperial citizens. The Mirror made it clear that it believed "the Maoris will not be outdone by the Pakehas in the warmth and sincerity of their greeting". 264 Stephen Hamilton draws attention to a portrait of a Te Arawa rangatira, Mita Taupopoki, which appeared in The Mirror's first royal number alongside the words of a traditional Māori greeting. He argues that it demonstrates how during the tour Māori were used by the Mirror to articulate a specifically New Zealand identity in the face of their foreign visitors: "In this portrait of what would have been regarded as an exemplary 'old-time Maori', Mita Taupopoki represented to readers of the Mirror an indigenous aristocracy, loyally British yet uniquely New Zealand".265 The description of the Duchess's encounter in Rotorua serves a similar function, in which the Māori woman's pūkana is read as a strange and exotic symbol of deference from a noble member of her race. Bella too is depicted as a proud woman whose pride is served by the fact that she has been selected to show

\footnotetext{
263 'Sidelights on Royal Visit', The Mirror, April 1927, p. 8.

264 'In the Mirror', The Mirror, February 1927, p. 6.

265 Hamilton, 'Reflecting Ourselves', p. 19.
} 
around such important and respected visitors. Māori are presented as representatives of a unique local culture, but one which was proud to be part of the British Empire.

There was tension that The Mirror did not cover. The Duke and Duchess' visit was the latest in a series of royal welcomes at Rotorua; both the Prince of Wales' royal tour in 1920 and his father's 1901 royal tour had paused in Rotorua to meet with Maori. In 1901 the Māori king, Mahuta Tāwhiao, objected to the choice of Rotorua as the location for the Māori welcome and refused to attend. Instead he suggested that he row out in his waka to meet the royals as they sailed into Auckland harbour. This idea was rejected by the government organisers, despite widespread support from an Auckland public who were delighted at the prospect of hosting such an authentic cultural demonstration. ${ }^{266}$ The subsequent suggestion that the tour might pause briefly at the Kīngitanga home at Ngāruawāhia to meet with the Māori king there was also rejected. In 1920 Waikato Māori once again elected not to attend the welcome at Rotorua, instead inviting the Prince to Ngāruawāhia. They were again refused. 'Princess' Te Puea Herangi, Waikato's most influential leader, was incensed, apparently publically berating Maui Pomare for the decision when she accidentally met with him in Frankton Junction. To ask Waikato Māori to visit the home of their traditional adversaries, Te Arawa, instead of greeting the Prince on their own ground was highly insulting and belittled the Kingitanga. ${ }^{267}$ Te Puea would continue to campaign for a royal visit to Ngāruawāhia during subsequent tours, including that of 1927, but her hopes were not fulfilled until after her death, when in 1953, Queen Elizabeth II stopped her tour at Tūrangawaewae Marae for twenty minutes. Those that did attend the gathering at Rotorua may well have had their own concerns. A royal tour was seen as an opportunity for Māori to present their grievances to representatives of the King, as representatives of Ngāti Porou demonstrated in 1901 when they performed a

\footnotetext{
${ }^{266}$ Judith Bassett, "A Thousand Miles of Loyalty': The Royal Tour of 1901', New Zealand Journal of History, Vol. 21, No. 2, 1987, p. 127.

${ }^{267}$ Michael King, Te Puea: A Life, $4^{\text {th }}$ Ed. (Auckland: Reed Books, 2003) pp. 107-108, 298-299.
} 
haka for the royal visitors which told the story of their suffering at the hands of land hungry Pākehā. 268

The Mirror's coverage of the tour certainly glosses over the underlying tensions that were no doubt present at Rotorua. But its representation of Māori as loyal imperial subjects is not necessarily a lie. The invitations to Ngāruawāhia made by successive Kīngitanga leaders were intended as acts of loyalty. Waikato Māori were eager for the opportunity to demonstrate their allegiance to the British crown; they simply wished to do it on their own ground. Te Puea was angry at the insult to her people, but she was also annoyed that Kingitanga supporters were perceived as disloyal and yet their attempts to prove their loyalty were not acknowledged. ${ }^{269}$ Those that approached the tour as an opportunity to air grievances demonstrated their faith in the royal family's ability to help solve their problems. There is no doubt that both tour organisers and The Mirror viewed Māori participation in the tour with certain agendas. Māori who decided to participate or not participate did so for their own reasons, but a desire to be recognised as imperial citizens could be one of these reasons.

The incredible popularity of the Duchess of York draws attention to ways in which women took increasing responsibility for the celebration and maintenance of empire. Her popularity was seen as a success for the empire, and during the tour the Mirror commented:

Gather together all the orators, economists, strategists and legislators of our Empire, and let them all deliberate and devise and plan till their vocabularies are exhausted and their ink has dried up,

\footnotetext{
268 Atholl Anderson, Judith Binney and Aroha Harris, Tangata Whenua: An Illustrated History (Wellington: Bridget Williams Books, 2014), p. 336.

269 King, pp. 107, 299.
} 
could they, think you, achieve half as much in Empire welding as our

Little Duchess is achieving to-day?270

This period was one in which women became increasingly visible as 'imperial agents', and royal and aristocratic women often set the tone. Queen Victoria was "the ultimate female imperialist icon", and her reign not only renewed enthusiasm for the British Empire generally but also inspired the formation of several women's imperialist organisations. ${ }^{271}$ Julia Bush's study of these organisations during the Edwardian period reveals a deep level of female engagement with the imperial project, but one which was dominated by ladies of the social elite. ${ }^{272}$ Many set up branches in New Zealand, and Katie Pickles' study of the Victoria League demonstrates that it remained a significant outlet for imperial patriotism of New Zealand's society matrons into the late twentieth century. ${ }^{273}$

However, the Victoria League was not the only organisation for women which expressed an imperial rhetoric, and women's imperialism was not just an activity of the elite. Pickles has pointed out that support for empire underpinned a wide variety of New Zealand women's organisations from Plunket to the Young Women's Christian Association and the Women's Division of Federated Farmers. ${ }^{274}$ Barbara Bush argues that as middle-class women's access to travel, education and political power increased in the early twentieth century they were able to participate more actively in the imperial work, leading to a 'feminisation' of the British empire. ${ }^{275}$ The impact of this work was felt in The Mirror. It commented in the wake of the royal tour that "many of our

270 'In the Mirror', The Mirror, June 1927, p. 6.

${ }^{271}$ Julia Bush, Edwardian Ladies and Imperial Power (London: Leicester University Press, 2000), p. 5; Katie Pickles, 'A Link in "the Great Chain of Friendship": The Victoria League in New Zealand', Journal of Imperial and Commonwealth History, Vol. 33, No. 1, 2005, p. 32.

272 Julia Bush, pp. 1-6.

273 Pickles, 'The Victoria League in New Zealand', pp. 44-45.

${ }^{274}$ Katie Pickles, 'Colonisation, Empire and Gender', in Giselle Byrnes (ed.), The New Oxford History of New Zealand (Melbourne: Oxford University Press, 2009), pp. 228-229.

275 Barbara Bush, 'Gender and Empire: The Twentieth Century', in Philippa Levine (ed.), Gender and Empire (Oxford: Oxford University Press, 2004), pp. 80-82. 
women have a far keener perception of the obligations of citizenship than have our menfolk". ${ }^{276}$ An article on the Victoria League praised its members for their "unswerving devotion to the Throne, and a passionate attachment to the Institutions and ideals of British citizenship". 277

One of most obvious ways in which women contributed to the strength of the empire was as mothers. The declining birth rate found across Britain and the white dominions lead to fears about 'race suicide'. As one Mirror article put it, "the fertile nations shall possess the earth", and white Britons were being outpaced. There were significant fears that the decreasing birth rate would led to a decline in British dominance:

They point to the fecundity of the black and yellow peoples, to China and Japan, even to Germany and Italy, predicting that within a measureable distance of time those broad red slashes which are Britain's share of the world map will have to yield to an entirely different colour scheme. ${ }^{278}$

The continued power of the British Empire was considered to be closely linked to its ability to breed new citizens. It was not just a question of quantity, however, but quality. Concerns about high numbers of men declared unfit to serve during the First World War led to a growing realisation that all the babies in the world could not build up the empire if they were not also healthy. According to Mein Smith, "the healthy white child was elevated to the status of a national resource, if not national treasure". ${ }^{279}$ Women's domestic role was therefore crucial to the imperial project. One Mirror article even suggested that women undergo compulsory domestic training. If men were expected to fight for their country, women should be prepared to "keep the home fire burning":

276 'In the Mirror', The Mirror, April 1927, p. 7.

277 'The Victoria League: Unification of Empire - Auckland Activities', The Ladies' Mirror, October 1922, pp. 6-7.

278 Charles Pilley, 'Those Missing Babies', The Mirror, May 1927, p. 43.

279 Philippa Mein Smith, 'Blood, Birth, Babies, Bodies', Australian Feminist Studies, Vol. 17, No.

39, 2002, p. 309. 
Since every man, whether rich or poor, owes it to the State to be able to shoulder a rifle and make things unpleasant for the invader, in case of need, so, they hold, the State may reasonably expect every woman, of whatever social standing, to qualify herself to keep the home fire burning in that or any other extremity. Cooking, housework, needlework, and the elements of sick nursing, in short, are in their opinion things which every woman ought to know, even if she is nurtured in the lap of luxury and can afford to hire a cook, a housemaid, a seamstress and a nurse. ${ }^{280}$

One answer was the Plunket Society, which was viewed as having a crucial role in improving the health and strength of the Empire. Erik Olssen argues that supporters attributed the Plunket method of childrearing with the power to improve both the martial capacity and the moral character of the empire through the production of healthy, self-disciplined citizens. ${ }^{281}$ Although Bryder has criticised Olssen's heavy reliance on King's personal beliefs for understanding Plunket, she too acknowledges that the organisation garnered much of its impetus and support through a strong imperial rhetoric.282 Philippa Mein Smith goes even further, pointing out the degree to which imperialist concerns and worries about the health of the race were found throughout public health discourse, not just within Plunket.283 It was Plunket, however, which became the most visible public symbol of racial health, and which was bought to the fore when the Duchess opened the Wellington Karitane Hospital during her visit.

The focus in these discussions about infant welfare on the 'health of the race' indicates that despite Māori's claim to be imperial citizens, imperialism in New Zealand was often fixated on whiteness. Plunket did not serve Māori families

280 'Domesticated by Order: Compulsory Training for Women', The Ladies' Mirror, June 1924, p. 27.

281 Olssen, 'Truby King and the Plunket Society', p. 21.

${ }^{282}$ Bryder, A Voice For Mothers, pp. 1-4; Linda Bryder, 'New Zealand's Infant Welfare Services and Maori, 1907-60', Health \& History, Vol. 3, 2001, p. 66 283 Mein Smith, Maternity in Dispute, pp. 2-3. 
until the 1940s and even then only in a limited capacity. Bryder explains how this was more complicated than simple racism; Māori health services were administered under a different system in which the Plunket Society was not permitted to interfere. ${ }^{284}$ But the emphasis placed on the welfare of Pākehā babies alone implied that they had an imperial importance that Māori babies did not possess. This is even more stark in the other solution to imperial strength advocated by The Mirror: eugenics. That more care was put into the breeding of cows and sheep than that of human children was seen as a travesty by The Mirror, which stated in an editorial that "The Mirror believes that the science of Eugenics is of such vital importance to humanity that its influence should dominate all creeds, all policies, all systems of social government". 285 Eugenics offered a supposedly scientific answer to the health of the race, eradicating disease and degeneracy by preventing the unfit from reproducing. According to The Mirror, "Australians and New Zealanders still have it in their power, by excluding colour, limiting entry to the best whites and preventing the unfit from breeding, to become, and remain, about the finest white strains in the world". ${ }^{286}$ The Mirror may have presented Māori as important members of the Empire during the royal tour, but elsewhere it demonstrated the belief that the future of the Empire lay in whiteness.

But motherhood was not the only outlet for women's imperialism. Youth organisations had an important role to play as well. As discussed earlier, organisations like the Girl Guides and the Young Women's Christian Association (YWCA) were praised by The Mirror for their capacity to teach young women values about loyalty and service at the same time as encouraging athleticism and the development of new skills. Importantly, however, these new youth organisations also often had a distinctly imperial flavour, encouraging members to become good citizens, not just of their local communities and nations, but of

\footnotetext{
${ }^{284}$ Bryder, 'New Zealand's Infant Welfare Services and Maori', pp.69-71.

285 'In the Mirror', The Mirror, August 1927, p. 6.

286 'Editorial Reflections: The Propagation of Mental Defectives; Making Housework Easy', The Mirror, September 1928, p. 8
} 
the empire. This is particularly visible within the Girl Guide movement. Kristine Alexander speaks of the Girl Guides' emphasis on an "imperial sisterhood", which encouraged guides to think of themselves as part of a wider, imperial movement.287 Tammy Proctor argues that "young people were pictured as both the hope and the downfall of British imperial power in the early twentieth century", and that youth organisations therefore played a crucial role in 'revitalising' the British Empire.288 The Mirror, commenting on the knighthood of the movement's leader, Robert Baden Powell, in 1927, wrote that both Guides and Scouts had been "of incalculable value to the Empire by creating a splendid spirit of citizenship amongst our boys and girls, besides inculcating worthy ideals for their guidance in the stern realities of life". 289 Youth organisations represented the future of the Empire; they were important because they allowed the imperial spirit to be passed on to the next generation in new ways.

Nor was imperialism, or at least a sense of imperial unity, absent from the various feminist organisations The Mirror reported on. One of the major feminist concerns during the period was that of married women's nationality. At that point, when a British woman (including New Zealand born women) married a foreign citizen she gave up her British citizenship and took on the nationality of her husband. There is no doubt that this was a serious feminist issue; women's lack of an independent nationality could have serious consequences, with British-born women being treated as enemy aliens during wartime and others ending up stateless. However, at least part of the distaste for the current law was rooted in indignation that British women could so easily be forced to give up their status as British citizens. Furthermore, the campaign to change the law was one which required cooperation and collaboration between feminist groups across the empire. Dorothy Page goes further, arguing

287 Kristine Alexander, 'The Girl Guide Movement and Imperial Internationalism during the 1920s and 1930s', Journal of the History of Childhood and Youth, Vol. 2, No. 1, 2009, p. 44. 288 Proctor, pp. 6-7.

289 'In the Mirror', The Mirror, July 1927, p. 7. 
that while the issue did affect New Zealand women, the interest of the National Council of Women was primary the result of a call to aid from their counterparts in Britain. ${ }^{290}$ In this case, and others, New Zealand feminists worked on common goals with their counterparts at 'home' and across the empire, particularly in the white dominions. They developed political power for women within the imperial context in a movement described by Pickles as 'imperial feminism'.291

Imperial unity did have its limits, however, and The Mirror was not always uncritical of New Zealand's relationship with Britain. The invention of refrigerated shipping is a key moment in Belich's recolonization theory, as he argues that the establishment of a British market for New Zealand meat and dairy was what tightened New Zealand's relationship with Britain. ${ }^{292}$ But its impact on the price of butter was a sore spot in The Mirror:

It is very gratifying to learn from Mr. Massey that in England housewives can buy New Zealand butter for one and fourpence a pound, eightpence less than the cost of Danish. He did not add that this is, moreover, about eightpence less than we have to pay for it ourselves - I wonder why? I would remind our worthy Premier that charity begins at home, and whilst we rejoice that New Zealand can play so material a part in assisting to cheapen the famous English breakfast-table, it would be even more a matter for congratulation if we could cheapen our own. ${ }^{293}$

The Mirror expressed a certain degree of pride that New Zealand butter was to be found on English breakfast tables, but it should not be at the expense of New Zealand housewives. After all, if New Zealand women's domestic activities were, as many argued, just as important to the strength of the empire as English

\footnotetext{
290 Page, 'Women and Nationality', p. 160.

291 Pickles, 'Colonisation, Empire and Gender', p. 229.

292 Belich, pp. 53-68.

293 'In the Mirror', The Ladies' Mirror, May 1924, p. 3,
} 
women's, then surely the imperial connection should not hinder their ability to provide for their families.

The royal tour was an imperial celebration, but it was also a celebration of New Zealand. Judith Bassett, discussing the 1901 royal tour, remarked that "royal tours are narcissistic festivals". 294 The royal tour provided an opportunity for New Zealanders not only to show off their loyalty, but also their own superiority. All of the nation's best features, from its beautiful scenery and unique indigenous population to its successes in industry and public health, were on display. Evident in the discussion of these is a growing sense that New Zealand possessed attributes which set it apart. In the editorial of the first Royal Tour issue, The Mirror stressed New Zealand's democratic and egalitarian nature. According to The Mirror "New Zealanders are essentially a democratic people although extremely loyal" and "pride themselves in their heritage as a free people, who scorn pandering to social rank or hereditary distinctions". 295 The absence of 'toadyism' in New Zealanders was similarly emphasised by local commentators during the 1901 tour. ${ }^{296}$ The success of Plunket and New Zealand's low infant mortality rate - the lowest in the world - proved that New Zealand was a superior place to raise children, and The Mirror's comments on eugenics betray not only a desire to further the British race as a whole, but to make New Zealand's portion one of the finest. The goal of establishing in New Zealand a 'better Britain' was one which had existed since the earliest days of the colony. The royal tour was an opportunity to prove that they had succeeded.

But the concept of a 'better Britain' was one that nonetheless emphasised the continued importance of Britain as a model. New Zealand was a modern, progressive nation but, The Mirror believed, the British Empire would remain its foundation. Embracing modernity was one way of revitalising and

\footnotetext{
294 Bassett, p. 135.

295 'In the Mirror', The Mirror, February 1927, p. 6.

296 Bassett, p. 136.
} 
strengthening these foundations, but Britain and the empire remained important to New Zealand's future. Alison Light uses the term 'conservative modernity' to describe the way in which the English middle classes quietly adsorbed the modern world into their everyday lives, and I was initially drawn to this as a way of describing The Mirror's royal celebrations; such imperial excitement seemed to me inherently conservative. But Light's conservative modernity is largely a passive response to modernity, "more about selfeffacement and retreat than bombast and expansion". 297 The Mirror is nearly always excited, enthusiastic about the modern world; it sees it not as something lost but something gained. If the magazine was conservative, its conservatism comes from the institutions by which it assumed this bright new world would continue to be underpinned: the monarchy, the empire, and the white middle class family. 


\section{Conclusion}

Most scholars have looked at The Mirror as part of literary history, or they have used it to answer questions about specific social trends or ideas. This is a study of The Mirror as a whole, a consideration of what the magazine was, and what it offered the women of interwar New Zealand. When The Mirror first appeared in 1922, its stated goal was to provide "every thoughtful woman... a medium which will give expressions to her own desires, aspirations and ideals". ${ }^{298}$ It was unlike anything New Zealand had seen before, a modern magazine for the modern woman with a wide range of content.

The Mirror formed part of a widening and successful print culture that developed in interwar New Zealand. Newspapers and periodicals like The Mirror integrated New Zealanders into a global web of reading and provided news and information from around the world. Magazines and newspapers were, as David Carter has suggested, "a mode of apprehending modernity".299 Magazines provided suggestions for navigating the modern world; they allowed questions about what to do and how to behave to be aired at a time when social boundaries seemed to be shifting. The act of reading the magazine was also a modern leisure activity, enjoyed by a mass reading public with the time to peruse and digest its contents. The Mirror's many advertisements also highlight the commercial importance of print media in a modern world of consumption and selling. Attracting advertisers was crucial to the financial success of a magazine, and The Mirror's success was dependent on its ability to appeal to consumers.

This study ends in 1932, but The Mirror did not. It continued to address New Zealand women for many years to come, finally ceasing publication in 1963. It successfully weathered the depression, providing reassurance to readers in a

298 'Editorial Reflections', The Ladies Mirror, July 1922, p. 10

299 Carter, p. 74.1. 
time of crisis, and survived the emergence of new local competitors in the form of the New Zealand Woman's Weekly and Woman To-Day. It remained an important part of New Zealand's print culture for much of the twentieth century.

The Mirror was, importantly, a women's magazine. Although it may have looked to overseas women's magazines for models, The Mirror forged a new path within the New Zealand print culture, establishing a successful local commercial women's press. The New Zealand Woman's Weekly soon followed in its wake; it was arguably more successful than The Mirror. But The Mirror was the first. It offered a gendered perspective that, in the 1920s, was unique. Its commercial success demonstrated the importance of women as consumers during this period. If magazines were a means of 'apprehending modernity', then The Mirror allowed women to see themselves as modern.

In The Mirror women were not tangential to modernity. They had a significant role to play in the creation of the modern world, as politicians, consumers, or the mothers of the next generation. The 1920s is not a decade marked by dramatic change in women's political position. Compared with the suffrage struggles found internationally over the preceding decades, the activities of interwar feminists may seem relatively tame. It is, however, a period marked by increasing organisation amongst women as they worked on a wide range of campaigns. The Mirror had a part to play in this organisational progress, providing a space for groups like the National Council of Women to reach and connect supporters, and spread awareness of the issues they wished to tackle. But The Mirror also demonstrates that despite relatively small political gains, women's lives did not remain static. The Mirror found change for women in the appliances they used in their homes and the clothes they wore. Perhaps most significantly, The Mirror identified wider shifts in women's outlook. Domesticity remained important, but no longer did women have to be married to live happy and fulfilling lives, and they had valuable contributions to make to the world outside their homes. 
In highlighting these changes The Mirror connected New Zealand women to worldwide debates about modernity and women's place within it. How were the freedoms and technologies of the modern world affecting the character of women? Were they improving or diminishing women's moral character, their domestic capabilities, their ability to contribute to society? These discussions could be found across the globe as societies grappled with the changes of the early twentieth century. They often reveal apprehension, uncertainty about the modern world of the 1920s. But they could also, as The Mirror demonstrates, elicit more positive reflections, a degree of cultural optimism.

These were global questions, but The Mirror provided a vision of modernity that was specific to New Zealand. The New Zealand modern girl, the 'girl of today', was happy and healthy and rarely drunk or decadent. She represented a bright future for the nation. In the home, modern 'labour saving' devices and techniques revolutionised household work, a development particularly welcome in a land where women had limited access to domestic help. The Plunket Society and other experts in childcare helped New Zealand women be better mothers, improving the health of their children and alleviating some of the fears of motherhood. Modern New Zealand was not perfect; The Mirror was disappointed by the limits on women's political achievement and noted the need for improvement in women's maternal health, amongst other issues. But overall, The Mirror depicted a modern world in which New Zealand women's lives were being improved by modernity.

The Mirror did not necessarily expect all its readers to agree. It acknowledged many apprehensions about the modern world, and sought to reassure its reading public. Articles on domestic appliances attempted to correct misconceptions about the cost of using electricity, while articles on the Plunket Society or other aspects of 'domestic science' sought to explain the principles behind these new approaches in ways that illuminated rather than confused. Mothercraft columns acknowledged the reasons why parents might be worried about the behaviour of their daughters, but they attempted to explain the motivations of young women in ways that were less alarming, and provided helpful advice for peaceful intergenerational coexistence. The Mirror acted as a 
mediator for modernity; explaining the positives of the modern world for the reader who might view them reluctantly, whether they be electricity or the modern girl.

The Mirror's celebration of modern life was paired with ideals that are less obviously modern. Most notable was the continued emphasis the magazine placed on the importance and strength of the British Empire. This came to the fore during the 1927 royal tour, but an imperial rhetoric is visible throughout The Mirror, from concern for white babies to praise of the Girl Guide movement. The Mirror also continued to place a high value on domesticity, something which has caused it and other magazines like it to be viewed as conservative. The Mirror, however, did not view these ideals to be in conflict with modernity. New movements, from the Girl Guides to the scientific eugenics movement, were seen as modern approaches that could help secure the empire's future. Modernity was not only to be celebrated because of the improvements it made to women's lives, but because it allowed for the strengthening and regeneration of ancient institutions, like empire and motherhood.

Unfortunately, The Mirror cannot tell us how readers responded to its content. The connection between what people read and how they lived is a perplexing question that is difficult to answer. New Zealanders of the 1920s probably found plenty to disagree with in the magazine's pages, and few would have followed all of its advice. But The Mirror's success indicates that people did find something in it worth reading. They may have found its content entertaining and informative, they may have found it shocking or provoking. But it clearly intrigued. It spoke to issues that people were concerned about, and even if they did not always agree with the solutions suggested by the magazine, it did enable public debate and consideration.

The Mirror offered a reflection of the modern world, acting, quite literally, as a mirror. The depiction of modernity in The Mirror may not have been identical to how readers themselves viewed it. Occasionally it reflected parts of the modern world that its readers could not, themselves, experience: behind the scenes at the royal palace, or the lives of women living in distant countries. It 
offered housewives a glimpse into the lives of professional women, and vice versa. The diversity of its content also meant that sometimes that reflection was refracted; the magazine could offer multiple, even contradictory, views on a single issue. But readers did see something recognisable in The Mirror. By holding a mirror up to the modern world, The Mirror provided an opportunity to evaluate and discuss, to take stock of modern life.

The Mirror is not just a source of the decade's public debate, but its visual culture as well. Its illustrated pages included images of fashionable women, recognisable public figures, and New Zealand's best homes. While many of these illustrations were images submitted by readers or commissioned by the magazine, others were commercial advertisements. The Mirror's advertisements featured the year's new model Ford, the attractive female body made possible with the help of Berlei undergarments, and a wide range of everyday household goods from toothpaste to baking powder. Many of these goods were novel. Cars, cosmetics and household appliances were the new apparatus of the modern women. The many images found in The Mirror provide a glimpse of the texture of modern life in the 1920s.

By 1932 the glint of modernity was perhaps beginning to dull. In June 1932 The Mirror's editorial dealt with two unrelated but similarly bleak topics: the failures of the ongoing Geneva Disarmament Conference, and the inadequacies of the New Zealand government's unemployment fund. ${ }^{300}$ The onset of the depression and the deterioration of peace in Europe made the thirties a decade in which it was harder to conceive of the modern world in entirely positive terms. The Mirror remained a reassuring presence, however, keeping up a steady commentary on how New Zealand was handling the crisis. While it had much to criticise about the government's response, The Mirror kept faith in New Zealand, declaring: "No other country possesses greater recuperative powers 
than the Dominion".301 The depression was a setback, to be sure, but a bright future remained within New Zealand's grasp. 


\section{Bibliography}

\section{PRIMARY SOURCES:}

\section{Periodicals and Other Publications:}

Auckland Star

The Mirror

New Zealand Woman's Weekly

The Otago Daily Times

Primmer, Melanie S. The Up-To-Date Housewife: Recipes, Food Suggestions and Family Hints for All Occasions (Dunedin: Coulls Summerville Wilkie, 1926).

\section{Archival Records:}

The Mirror Publishing Company Ltd Records, 1922-1923, Box No. 404/2283:1922/24, R9094591, Archives New Zealand, Auckland.

The Mirror Publishing Company Ltd Records, 1923-c. 1981, Box No. 3383/28646:1923/139, R6359277, Archives New Zealand, Auckland.

\section{SECONDARY SOURCES:}

\section{Books:}

Anderson, Atholl, Binney, Judith and Harris, Aroha, Tangata Whenua: An Illustrated History (Wellington: Bridget Williams Books, 2014).

Ballaster, Ros, Beetham, Margaret and Hebron, Sarah, Women's Worlds: Ideology, Femininity, and the Woman's Magazine (Houndmills: Macmillan, 1991).

Beetham, Margaret, A Magazine of Her Own?: Domesticity and Desire in the Women's Magazine, 1800-1914 (Routledge: New York, 1996).

Belich, James, Paradise Reforged: A History of the New Zealanders from the $1880 \mathrm{~s}$ to the Year 2000 (Auckland: Penguin Books, 2001).

Benson, Susan Porter, Counter Cultures: Saleswomen, Managers and Customers in American Department Stores, 1890-1940 (Chicago: University of Illinois Press, 1988).

Bingham, Adrian, Gender, Modernity and the Popular Press in Inter-War Britain, (Oxford: Clarendon Press, 2004). 
Blackwell, Janet (ed.), NZ Woman's Weekly: The First 60 Years, 1932-1992 (Auckland: Moa Beckett Publishers, 1992).

Bland, Lucy, Modern Woman on Trial: Sexual Transgression in the Age of the Flapper (Manchester: Manchester University Press, 2013).

Broad, Lewis, The Abdication: Twenty Years After (London: Frederick Muller, 1961).

Bryder, Linda, A Voice For Mothers: The Plunket Society and Infant Welfare 19072000 (Auckland: Auckland University Press, 2003).

Julia Bush, Edwardian Ladies and Imperial Power (London: Leicester University Press, 2000).

Clarsen, Georgine, Eat My Dust: Early Woman Motorists (Baltimore: Johns Hopkins University Press, 2008).

Coney, Sandra (ed.), Standing in the Sunshine: A History of New Zealand Women Since They Won The Vote (Auckland: Penguin Books, 1993).

Culleton, Claire, Working-Class Culture, Women, and Britain, 1914-1921 (New York: St. Martin's Press, 1999).

Daley, Caroline, Leisure and Pleasure: Reshaping and Revealing the New Zealand Body, 1900-1960 (Auckland: Auckland University Press, 2003).

Darrow, Margaret, French Women and the First World War (Oxford: Berg, 2000).

Davies, Valerie, Royal Tourists: 120 Years of Royal Visits to New Zealand (Auckland: Random House, 1989).

Felski, Rita, The Gender of Modernity (Cambridge: Harvard University Press, 1995).

Giles, Judy, The Parlour and the Suburb: Domestic Identities, Class, Femininity and Modernity (Oxford: Berg, 2004).

Gough-Yates, Anna, Understanding Women's Magazines: Publishing, Markets and Readerships (London: Routledge, 2003).

Hastings, David, Extra! Extra! How the People Made the News (Auckland: Auckland University Press, 2013).

Holt, Marilyn Irvin, Linoleum, Better Babies and The Modern Farm Woman, 1890 1930 (Albuquerque: University of New Mexico Press, 1995).

Hilliard, Chris, The Bookmen's Dominion: Cultural Life in New Zealand 19201950, (Auckland: Auckland University Press, 2006). 
Kent, Susan Kingsley, Making Peace: The Reconstruction of Gender in Interwar Britain (Princeton: Princeton University Press, 1993).

King, Michael, Te Puea: A Life, 4th Ed. (Auckland: Reed Books, 2003).

Laurenson, Helen B. Going Up, Going Down: The Rise and Fall of the Department Store (Auckland: Auckland University Press, 2005).

Leach, Helen, Kitchens: The New Zealand Kitchen in the 20 ${ }^{\text {th }}$ Century (Dunedin: Otago University Press, 2014).

Light, Alison, Forever England: Femininity, Literature and Conservatism Between the Wars (London: Routledge, 1991).

Lynch, Jenny, New Zealand Woman's Weekly: 70 years from Pavlovas to Prime Ministers (Auckland, Random House, 2002).

Macdonald, Charlotte, Strong, Beautiful and Modern: National Fitness in Britain, New Zealand, Australia and Canada, 1935-1960 (Wellington: Bridget Williams Books, 2011).

Macdonald, Charlotte, The Vote, the Pill and the Demon Drink: A History of Feminist Writing in New Zealand, 1869-1993 (Wellington: Bridget Williams Books, 1993).

Mein Smith, Philippa Maternity in Dispute: New Zealand, 1920-1939 (Wellington: Historical Publications Branch, Department of Internal Affairs, 1986).

Melman, Billie, Women and the Popular Imagination in the Twenties: Flappers and Nymphs (New York: St. Martin's Press, 1988).

Murphy, Philip, Monarchy and the End of Empire: The House of Windsor, the British Government and the Postwar Commonwealth (Oxford: Oxford University Press, 2013).

Nairn, Tom, The Enchanted Glass: Britain and its Monarchy (London: Radius, 1988).

Olssen, Erik, Building the New World: Work, Politics and Society in Caversham, 1880s-1920s (Auckland: Auckland University Press, 1995).

Olssen, Erik, Griffen, Clyde and Jones, Frank, An Accidental Utopia? Social Mobility and the Foundations of an Egalitarian Society, 1880-1940 (Dunedin: Otago University Press, 2011).

Page, Dorothy, The National Council of Women: A Centennial History (Auckland: Auckland University Press, 1996). 
Phillips, Jock, A Man's Country? The Image of the Pakeha Male: A History (Auckland: Penguin, 1987).

Prochaska, F. K. Women and Philanthropy in Nineteenth Century England (Oxford: Clarendon Press, 1980).

Proctor, Tammy, On My Honour: Guides and Scouts in Interwar Britain (Philadelphia: American Philosophical Society, 2002).

Rappaport, Erika Diane, Shopping for Pleasure: Women in the Making of London's West End (Princeton: Princeton University Press, 2000).

Reiger, Kerreen M. The Disenchantment of the Home: Modernising the Australian Family 1880-1940 (Melbourne: Oxford University Press, 1985).

Roberts, Mary Louise, Civilization Without Sexes: Reconstructing Gender in Postwar France, 1917-1927 (Chicago: University of Chicago Press, 1994).

Scholefield, Guy H. Newspapers in New Zealand (Wellington: A. H. \& A. W. Reed, 1958).

Søland, Brigitte, Becoming Modern: Young Woman and the Reconstruction of Womanhood in the 1920s (Princeton: Princeton University Press, 2000).

Wevers, Lydia, Reading on the Farm: Victorian Fiction and the Colonial World (Wellington: Victoria University Press, 2010).

Wilson, Elizabeth, Adorned in Dreams, revised ed. (London: I.B. Tauris, 2003).

Winship, Janice, Inside Women's Magazines (New York: Pandora, 1987).

White, Cynthia L. Women's Magazines 1693-1968 (London: Michael Joseph Ltd, 1970).

Woollacott, Angela, On Her Their Lives Depend: Munitions Workers in the Great War (Berkeley: University of California Press, 1994).

Yska, Redmer, Truth: The Rise and Fall of the People's Paper (Nelson: Craig Potton Publishing, 2010).

\section{Articles and Chapters from Edited Collections:}

Alexander, Kristine 'The Girl Guide Movement and Imperial Internationalism During the 1920s and 1930s', Journal of the History of Childhood and Youth, Vol. 2, No. 1, 2009, pp. 37-63.

Alexander, Sally, 'Becoming a Woman in London in the 1920s and 1930s', in David Feldman and Gareth Stedman Jones (eds.), Metropolis London: Histories and Representations Since 1800 (London: Routledge, 1989), pp. 245-271. 
Baldwin, Davarian L. 'From the Washtub to the World: Madam C. J. Walker and the "Re-Creation" of Race Womanhood, 1900-1935', in The Modern Girl Around the World Research Group, The Modern Girl Around the World: Consumption, Modernity, and Globalisation (Durham: Duke University Press, 2008), pp. 55-76.

Ballantyne, Tony, 'Reading the Newspaper in Colonial Otago', Journal of New Zealand Studies, No. 12, 2011, 47-63.

Bassett, Judith, 'A Thousand Miles of Loyalty': The Royal Tour of 1901', New Zealand Journal of History, Vol. 21, No. 2, 1987, pp. 125-138.

Brookes, Barbara, 'Reproductive Rights: The Debate Over Abortion and Birth Control in the 1930s', in Barbara Brookes, Charlotte Macdonald and Margaret Tennant (eds.), Women in History: Essays on European Women in New Zealand (Wellington: Allen \& Unwin, 1986), pp. 119-136.

Bryder, Linda, 'New Zealand's Infant Welfare Services and Maori, 1907-60', Health \& History, Vol. 3, 2001, pp. 65-86.

Bryder, Linda, 'Perceptions of Plunket: Time to Review Historians' Interpretations?', in Linda Bryder and Derek A. Dow, New Countries and Old Medicine: Proceedings of An International Conference on the History of Medicine and Health, Auckland, 1994, pp. 98-102.

Bush, Barbara, 'Gender and Empire: The Twentieth Century', in Philippa Levine (ed.), Gender and Empire (Oxford: Oxford University Press, 2004), pp. 77-112.

Cannadine, David, 'The Context, Performance and Meaning of Ritual: The British Monarchy and the 'Invention of Tradition', c. 1820-1977', in Eric Hobsbawm and Terence Ranger (eds.), The Invention of Tradition (Cambridge University Press, Cambridge, 1983), pp. 101-164.

Carter, David, “"Esprit de Nation” and Popular Modernity: Aussie Magazine 1920-1931', History Australia, Vol. 5, No. 3, 2008, pp. 74.1-74.22.

Clarke, Alison, "With One Accord Rejoice on this Glad Day": Celebrating the Monarchy in Nineteenth-Century Otago', The New Zealand Journal of History, Vol. 36, No. 2, 2002, pp. 138-160.

Conekin, Becky; Mort, Frank and Waters, Chris, 'Introduction', in Becky Conekin, Frank Mort and Chris Waters (eds.), Moments of Modernity: Reconstructing Britain 1945-1964 (London: Rivers Oram Press, 1999), pp. 1-21.

Coney, Sandra, 'Geddes, Annabella Mary', Dictionary of New Zealand Biography, Vol. 4, 1996, http://www.teara.govt.nz/en/biographies/3g4/geddes-annabellamary, accessed 13 December 2014. 
Connor, Liz, "Blackfella Missus Too Much Proud": Techniques of Appearing, Femininity and Race in Australian Modernity', in The Modern Girl Around the World Research Group, The Modern Girl Around the World: Consumption, Modernity, and Globalisation (Durham: Duke University Press, 2008), pp. 220239.

Dalley, Bronwyn, 'The Cultural Remains of Elsie Walker', in Bronwyn Dalley and Bronwyn Labrum (eds.) Fragments: New Zealand Social and Cultural History (Auckland: Auckland University Press, 2000), pp. 140-162.

Darwin, John, 'A Third British Empire? The Dominion Idea in Imperial Politics', in Judith M. Brown and Wm. Roger Louis (eds.), The Oxford History of the British Empire Vol. IV: The Twentieth Century (Oxford: Oxford University Press, 1999), pp. 47-63.

Elphick, Judith, 'What's Wrong With Emma? The Feminist Debate in Colonial Auckland', New Zealand Journal of History, Vol. 9, No. 2, 1975, pp. 126-141.

Greenhalgh, Charlotte, 'Bush Cinderellas: Young New Zealanders and Romance at the Movies, 1919-1939', New Zealand Journal of History, Vol. 44, No. 1, 2010, pp. 1-21.

Hamilton, Stephen, 'Reflecting Ourselves: "Maoriland” in the Mirror', Journal of New Zealand Studies, Vol. 8, No. 1, March 1998, pp. 14-21.

Knott, John William, 'The 'Conquering Car': Technology, Symbolism and the Motorisation of Australia before World War II', Australian Historical Studies, Vol. 31, No. 114, pp. 1-26.

Kumarasingham, Harshan, 'Independence and Identity Ignored? New Zealand's Reactions to the Statute of Westminster', in National Identities, Vol. 12, No. 2, 2010, pp. 147-160.

Leach, Helen M. 'The European House and Garden in New Zealand', in At Home in New Zealand: History, Houses, People (Wellington: Bridget Williams Books, 2000), pp. 73-89.

Macdonald, Charlotte, 'Burnard, Norah Telford', Dictionary of New Zealand Biography, Vol. 5, 2000, http://www.teara.govt.nz/en/biographies/5b49/burnard-norah-telford, accessed 14 Jan 2015.

Macdonald, Charlotte, 'Strangers At The Hearth: The Eclipse of Domestic Service in New Zealand Homes c. 1830-1940s', in Barbara Brookes (ed.) At Home in New Zealand: History, Houses, People (Wellington, Bridget Williams Books, 2000), pp. 41-56. 
McEldowney, Dennis, 'Publishing, Patronage, Literary Magazines', in Terry Sturm (ed.) The Oxford History of New Zealand Literature, 2nd Ed. (Auckland: Oxford University Press, 1996), pp. 631-694.

Mein Smith, Philippa, 'Infant Welfare Services and Infant Mortality: A Historian's View', Australian Economic Review, No. 93, 1991, pp. 22-34.

Meyorwitz, Joanne, 'Beyond the Feminine Mystique: A Reassessment of Postwar Mass Culture, 1946-1958', Journal of American History, Vol. 79, No. 4, 1993, pp. 1455-1482.

Modern Girl Around the World Research Group, 'The Modern Girl as Heuristic Device: Collaboration, Connective Comparison, Multidirectional Citation', in The Modern Girl Around the World Research Group, The Modern Girl Around the World: Consumption, Modernity, and Globalisation (Durham: Duke University Press, 2008), pp. 1-24.

Modern Girl Around the World Research Group, 'The Modern Girl Around the World: Cosmetics Advertising and the Politics of Race and Style', in The Modern Girl Around the World Research Group, The Modern Girl Around the World: Consumption, Modernity, and Globalisation (Durham: Duke University Press, 2008), pp. 25-54.

Nava, Mica, 'Modernity's Disavowal: Women, the City, and the Department Store', in Mica Nava and Alan O'Shea (eds.), Modern Times: Reflections on a Century of English Modernity (London: Routledge, 1996), pp. 38-76.

O'Donnell, Jean-Marie, “Electric Servants' and the Science of Housework: Changing Patterns of Domestic Work, 1935-1956', in Barbara Brookes, Charlotte Macdonald and Margaret Tennant (eds.), Women in History 2 (Wellington: Bridget Williams Books, 1992), pp. 168-183.

Olssen, Erik, 'Towards A New Society' in W. H. Oliver (ed.), The Oxford New History of New Zealand (Wellington: Oxford University Press, 1981), pp. 250278.

Olssen, Erik, 'Truby King and the Plunket Society: An Analysis of a Prescriptive Ideology', New Zealand Journal of History, Vol. 15, No. 1, 1981, pp. 3-23.

Olssen, Erik, 'Working Gender, Gendering Work: Occupational Change and Continuity in Southern Dunedin' in Barbara Brookes, Annabel Cooper and Robin Law (ed.), Sites of Gender: Women, Men \& Modernity in Southern Dunedin (Auckland: Auckland University Press, 2003), pp. 40-90.

Page, Dorothy, 'Women and Nationality: Feminist Organisations in the InterWar Period', in Barbara Brooks, Charlotte Macdonald and Margaret Tennant 
(eds.), Women in History: Essays on European Women in New Zealand (Wellington: Allen \& Unwin, 1986), pp. 157-175.

Peiss, Kathy, 'Girls Lean Back Everywhere', in The Modern Girl Around the World Research Group, The Modern Girl Around the World: Consumption, Modernity, and Globalisation, (Durham: Duke University Press, 2008), pp. 347353.

Pickles, Katie, 'A Link in "the Great Chain of Friendship": The Victoria League in New Zealand', Journal of Imperial and Commonwealth History, Vol. 33, No. 1, 2005, pp. 29-50.

Pickles, Katie, 'Colonisation, Empire and Gender', in Giselle Byrnes (ed.), The New Oxford History of New Zealand (Melbourne: Oxford University Press, 2009), pp. 219-242.

Rabel, Roberto, 'New Zealand's Wars', in Giselle Byrnes (ed.), The New Oxford History of New Zealand (Melbourne: Oxford University Press, 2009), pp. 245267.

Reed, Charles V. 'The Royal Tour of 1901 and Imperial Citizenship in South Africa', in C. McGlynn, A. Mycock and J. W. McAuley (eds.), Britishness, Identity and Citizenship: The View From Abroad (Bern: Peter Lang, 2011), pp. 11-30.

Roberts, Evan, "'Don't Sell Things, Sell Effects": Overseas Influences in New Zealand Department Stores, 1909-1956', Business History Review, Vol. 77, No. 2 , 2003, pp. 265-289.

Ross, Angus, 'Reluctant Dominion or Dutiful Daughter? New Zealand and the Commonwealth in the Inter-War Years', Journal of Commonwealth Political Studies, Vo. 10, No. 1, 1972, p. 28-44.

Ryan, Louise, 'Locating the Flapper in Rural Irish Society: The Irish Provincial Press and the Modern Woman in the 1920s', in Ann Heilmann and Margaret Beetham (ed.) New Woman Hybridities: Femininity, Feminism, and International Consumer Culture, 1880-1930, (London: Routledge, 2004), pp. 90-101.

Sprecher, Danielle, 'Good Clothes are Good Business: Gender, Consumption and Appearance in the Office, 1918-39', Caroline Daley and Deborah Montgomerie (eds.) The Gendered Kiwi (Auckland: Auckland University Press, 1999) pp. 141162.

Stein, Sally, 'The Graphic Ordering of Desire: Modernization of a Middle-Class Women's Magazine, 1919-1939', in Richard Bolton (ed.), The Contest of Meaning: Critical Histories of Photography (Cambridge: MIT Press, 1989), pp. 145-161. 
Stone, R. C. J. 'Kelliher, Henry Joseph', Dictionary of New Zealand Biography, Vol. 4, 1998, http://www.teara.govt.nz/en/biographies/4k5/kelliher-henry-joseph, accessed 28 April 2014

Thomas, Lynn M. 'The Modern Girl and Racial Respectability in 1930s South Africa', in The Modern Girl Around the World Research Group, The Modern Girl Around the World: Consumption, Modernity, and Globalisation (Durham: Duke University Press, 2008), pp. 96-119.

Tye, J. Reginald, 'New Zealand', in J. Don Vann and Rosemary T. VanArsdel (eds.), Periodicals of Queen Victoria's Empire (Toronto: University of Toronto Press, 1996), pp. 203-240.

\section{Theses:}

Corbitt, Jenn, "'Shimmering Images": Gender, Modernity and The Mirror, 19221938'. BA Hons Thesis, Victoria University of Wellington, 2000.

Hamilton, Stephen, 'New Zealand English Language Periodicals of Literary Interest Active 1920s-1960s', PhD Thesis, University of Auckland, 1996.

Hughes, Chanel, 'Dolce Cabot and the Canterbury Times "Ladies' Page": An Examination of Early New Zealand Women's Journalism', MA Thesis, University of Canterbury, 1998.

Liebich, Susann, 'Connected Readers: Reading Practises and Communities Across the Empire, c. 1890-1920', PhD Thesis, Victoria University of Wellington, 2012.

North, R. F. 'Representations of Women in New Zealand: A Study of Parliamentary Debate, the New Zealand Woman's Weekly, and Broadsheet, from the 1950s to the 1980s', MA Thesis, University of Auckland, 1993.

Upton, Susan, 'Women in the Club: Women's Clubs in the Wellington Region, 1895-1945', MA Thesis, Victoria University of Wellington, 1993. 